Prepared in cooperation with Waccasassa Bay Preserve State Park and Florida Springs Initiative

\title{
Thermal Imaging of the Waccasassa Bay Preserve: Image Acquisition and Processing
}

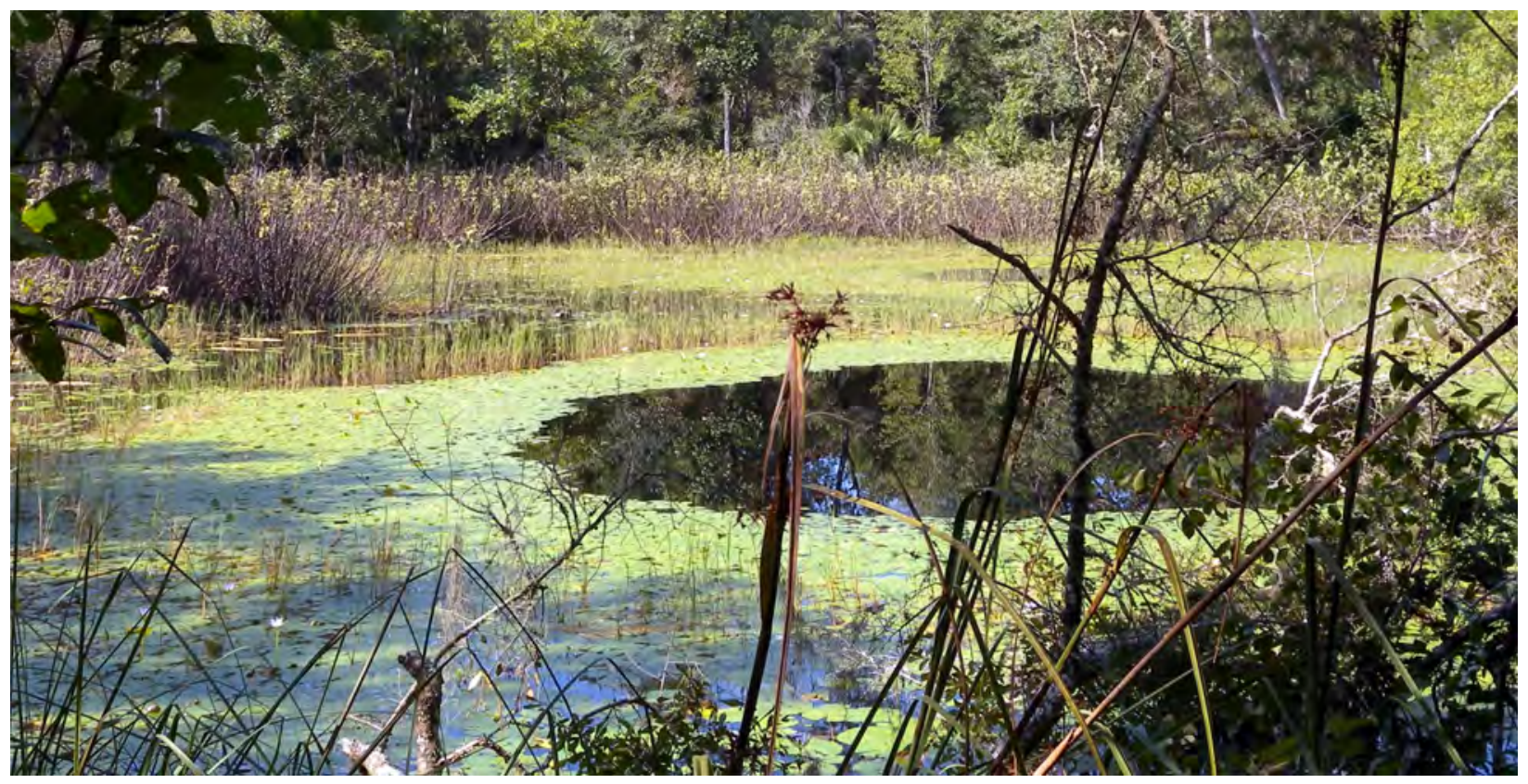

Open-File Report 2010-1120 



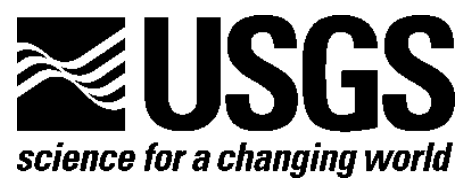

Prepared in cooperation with Waccasassa Bay Preserve State Park and Florida Springs Initiative

\section{Thermal Imaging of the Waccasassa Bay Preserve: Image Acquisition and Processing}

By Ellen A. Raabe and Elzbieta Bialkowska-Jelinska

Open-File Report 2010-1120

U.S. Department of the Interior

U.S. Geological Survey 


\section{U.S. Department of the Interior \\ KEN SALAZAR, Secretary}

\section{U.S. Geological Survey \\ Marcia K. McNutt, Director}

U.S. Geological Survey, Reston, Virginia 2010

For product and ordering information:

World Wide Web: http://www.usgs.gov/pubprod

Telephone: 1-888-ASK-USGS

For more information on the USGS-the Federal source for science about the Earth, its natural and living resources, natural hazards, and the environment:

World Wide Web: http://www.usgs.gov

Telephone: 1-888-ASK-USGS

Suggested citation:

Raabe, E.A. and Bialkowska-Jelinska, E., 2010, Thermal Imaging of the Waccasassa Bay Preserve: image acquisition and processing: U.S. Geological Survey Open File Report 2010-1120, 61 p.

Any use of trade, product, or firm names is for descriptive purposes only and does not imply endorsement by the U.S. Government.

Although this report is in the public domain, permission must be secured from the individual copyright owners to reproduce any copyrighted material contained within this report. 


\section{Contents}

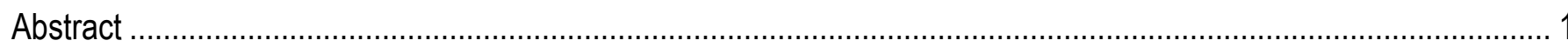

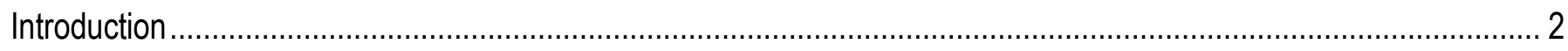

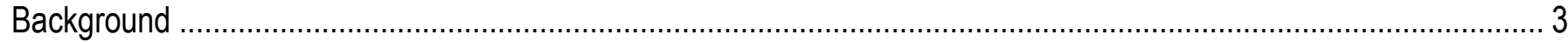

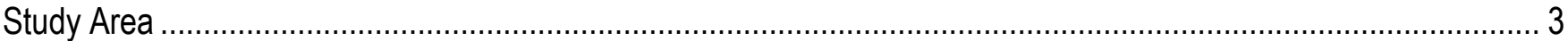

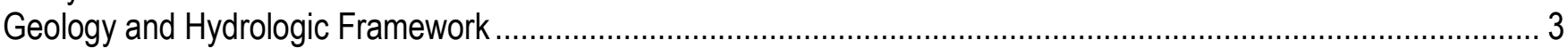

Application of Thermal Infrared Imagery in Landscape Analysis ................................................................... 8

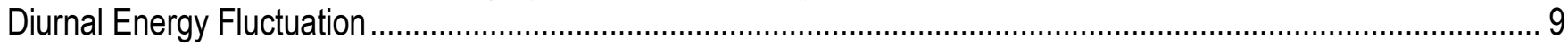

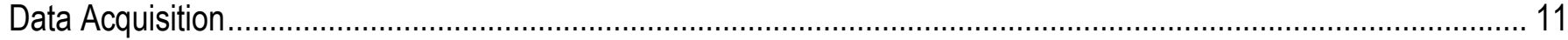

Weather and Climatic Conditions during Data Acquisition ............................................................................ 11

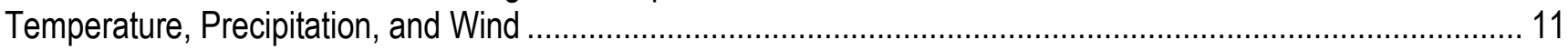

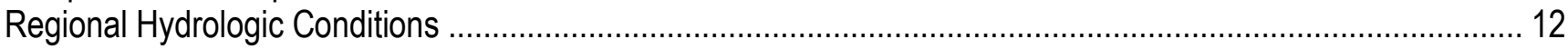

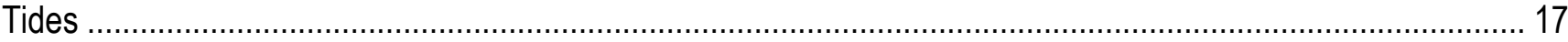

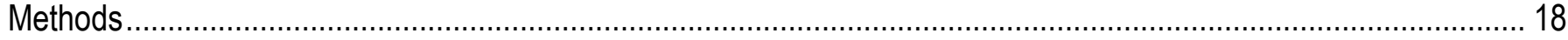

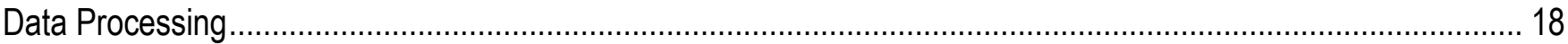

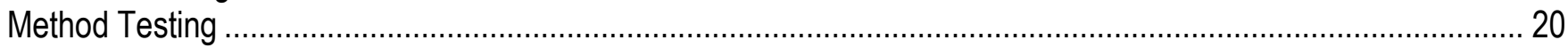

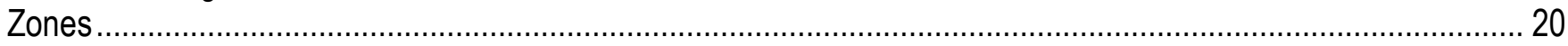

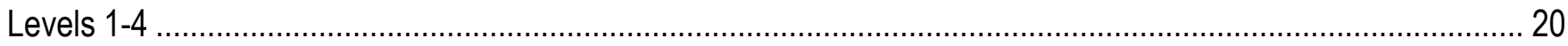

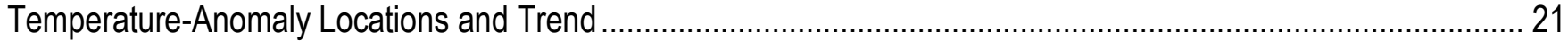

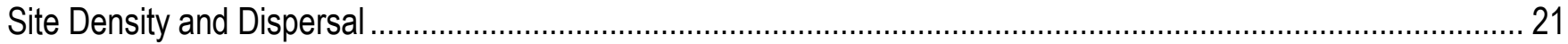

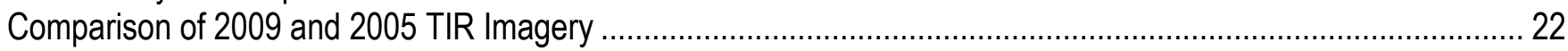

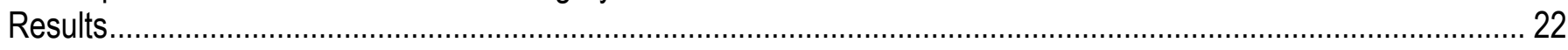

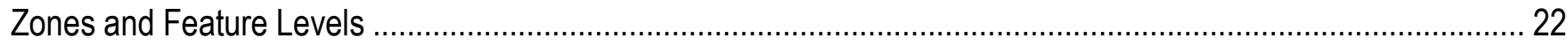

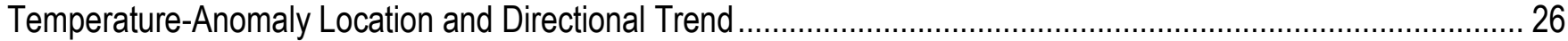

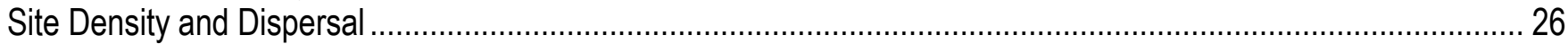

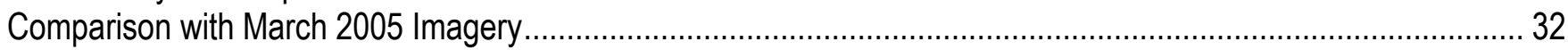

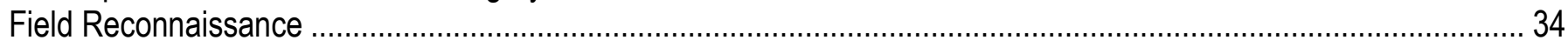

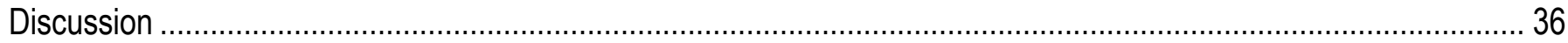

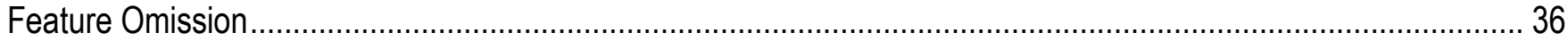

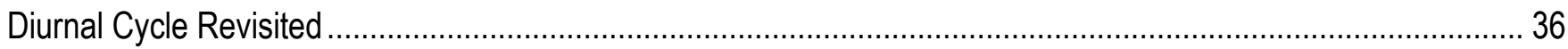

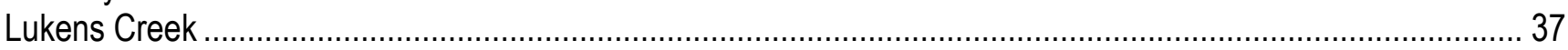

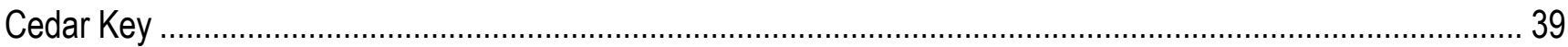

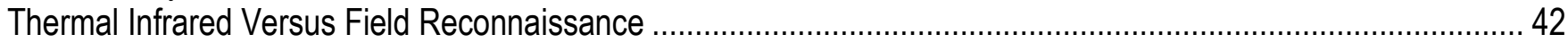

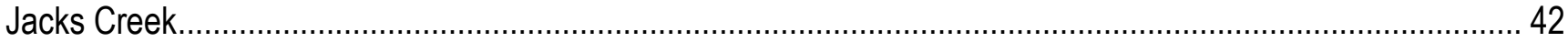

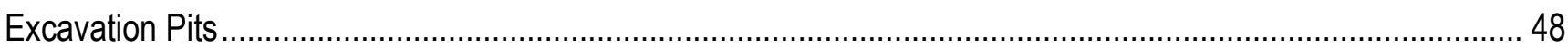

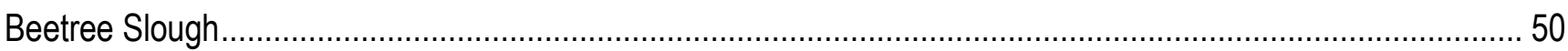

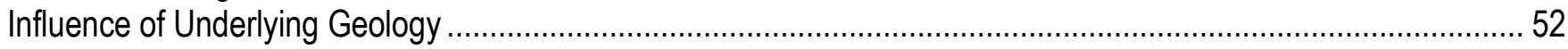

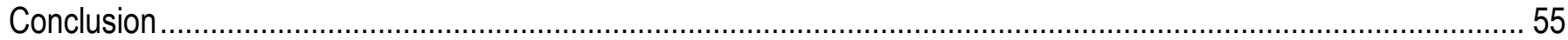

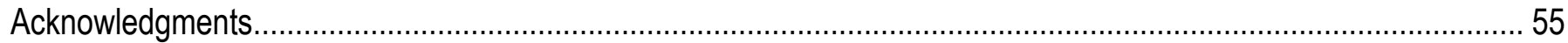

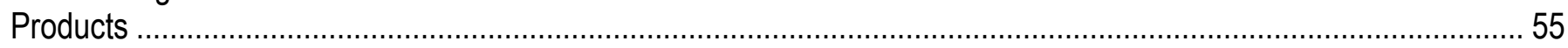

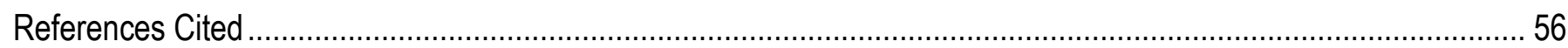




\section{Figures}

Figure 1. Waccasassa Bay Preserve thermal-imaging study area and surrounding region. ....................................... 4

Figure 2. Study area showing relative location of springs, faults, and fracture lines. ............................................. 5

Figure 3. Photo showing limestone fractures and surface dissolution in WBPSP near Kelly Creek............................. 6

Figure 4. Photo showing rolling limestone plain and log debris in eastern region of WBPSP ……........................... 7

Figure 5. Diurnal cycle of heating and cooling (adapted from Drury, 2001, used with permission). ........................... 10

Figure 6. SRWMD rainfall record, March 2008-March 2009, showing March 2009 highlighted in blue...................... 12

Figure 7. Usher Tower rainfall record 1982-2008 ............................................................................... 13

Figure 8. River discharge: a. Suwannee River near Wilcox, b. Waccasassa River near Gulf Hammock, c. Withlacoochee

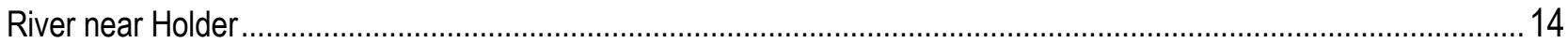

Figure 9. Groundwater levels in USGS observation wells: a. Rosewood Tower, b. Tidewater Well Number I........... 16

Figure 10. Predicted and observed tide levels (WLs) at Cedar Key for March 29-30, 2009.................................... 17

Figure 11. March 2009 TIR imagery, color-mapped for temperature, showing Creek, Bay, and Gulf zones............... 19

Figure 12. Image overlap and area of comparison between March 2005 and March 2009 night TIR ......................... 23

Figure 13. Waccasassa Bay region temperature-anomaly Levels 1-4 showing submarine seep sites. .......................2

Figure 14. Winzy Creek TIR imagery showing Levels 1-4 along tidal creek........................................................ 27

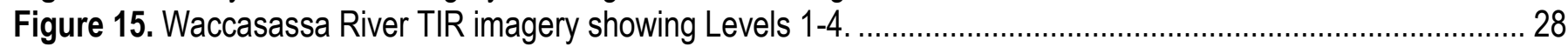

Figure 16. Level 4 temperature-anomaly point locations color-coded as natural or artificial features. ........................29

Figure 17. Trend ellipse of natural temperature anomalies aligned in a northwest direction with fault strikes. ............30

Figure 18. Density of Level 4 temperature anomalies showing clustering and isolation of features........................... 31

Figure 19. Photo showing Lancaster Spring looking north along the spring run, February 2009............................. 32

Figure 20. Thermal signature at Lancaster Spring was low in 2009 TIR (a) compared to 2005 TIR (b).................... 33

Figure 21. Field reconnaissance locations and area names....................................................................... 35

Figure 22. Photo showing Level 4 pond at Lukens Creek surrounded by high marsh and pine hammocks................ 37

Figure 23. Lukens Creek Level 4 ponds contrast with cooler landscape: a. Color infrared, b. Thermal infrared......... 38

Figure 24. Photo showing mudflat near Cedar Key exposed at low tide, looking west............................................. 39

Figure 25. Photo showing shallow boat bay between hotels and condominiums in Cedar Key. ............................... 40

Figure 26. Cedar Key swimming pools are Level 4 sites: a. CIR, b. TIR. ……................................................. 41

Figure 27. Photo showing Jacks Creek Level 4 twin ponds in dry season with corkwood at perimeter of two mud holes in May 2009.

Figure 28. Jacks Creek a. CIR image, b. TIR image shows Level 4 ponds in contrast with ambient temperature in ordinary depressions.

Figure 29. Photo showing Level 4 site near Jacks Creek with murky rust-colored water and bird rookery. ................ 44

Figure 30. Photo showing large Level 1 limestone-rimmed pond near Jacks Creek with alligators in rock caverns. State employees making observations and water-quality measurements.

Figure 31. Photo showing control site near Jacks Creek with murky water, mud bar, marsh and coastal forest........ 45

Figure 32. Photo showing USGS scientist at control site 100 yds east of Jacks Creek twin ponds, ......................... 45

Figure 33. Photo showing Jacks Creek twin ponds September 2009 flooded to corkwood perimeter with two water-surface clearings at location of May mud holes..

Figure 34. Photo showing solution hole near Jacks Creek: water surface $3 \mathrm{ft}$ below ground surface, 4 ppt and

$71^{\circ} \mathrm{F}$ at depth, May 2009.

Figure 35. Photo showing excavation pits on Robinson Rd. with freshwater and large Level 4 thermal anomalies................. 48

Figure 36. Water-filled excavation pits near Cow Creek had large temperature anomalies, a. CIR, b. TIR ............... 49

Figure 37. Photo showing irregularly shaped, limestone-lined, Level 4 pond with deep pool near Beetree Slough. .................50

Figure 38. Temperature anomalies at the marsh and forest boundary near Beetree Slough, a. CIR, b. TIR ..............51 
Figure 39. Photo showing Level 4 pond near Beetree Slough with aquatic plants, rock exposures, and coastal forest.

Figure 40. Photo showing Level 3 pond near Beetree Slough surrounded by coastal forest and high marsh 53

Figure 41. Photo showing WBPSP Park manager, K. Ebersol, standing between uprooted red cedar with salt grass colonizing sediments.

\section{Tables}

Table 1. Nearby temperature and salinity records for March 29-30, 2009....................................................... 12

Table 2. Summary statistics and temperature range in three zones for ambient surface water and Levels 1-4......... 22

Table 3. Temperature conversion, image values, ambient surface-water temperature, and feature range................ 24

Table 4. Acreage of Creek, Bay, and Gulf zones and significant temperature, Levels 1-4, in each zone.................. 26 


\section{Conversion Factors}

\begin{tabular}{lcl}
\hline & \multicolumn{1}{c}{ Bultiply } & \multicolumn{1}{c}{ To obtain } \\
\hline inch (in.) & Length & \\
foot (ft) & 2.54 & centimeter $(\mathrm{cm})$ \\
mile (mi) & 0.3048 & meter $(\mathrm{m})$ \\
yard (yd) & 1.609 & kilometer $(\mathrm{km})$ \\
\hline & 0.9144 & meter $(\mathrm{m})$ \\
\hline acre & Area & \\
acre & 4,047 & square meter $\left(\mathrm{m}^{2}\right)$ \\
acre & 0.4047 & hectare $($ ha) \\
square foot $\left(\mathrm{ft}^{2}\right)$ & 0.004047 & square kilometer $\left(\mathrm{km}^{2}\right)$ \\
square foot $\left(\mathrm{ft}^{2}\right)$ & 929.0 & square centimeter $\left(\mathrm{cm}^{2}\right)$ \\
square mile $\left(\mathrm{mi}^{2}\right)$ & 0.09290 & square meter $\left(\mathrm{m}^{2}\right)$ \\
square mile $\left(\mathrm{mi}^{2}\right)$ & 259.0 & hectare $($ ha) \\
\hline & 2.590 & square kilometer $\left(\mathrm{km}^{2}\right)$ \\
\hline cubic foot per second $\left(\mathrm{ft}^{3} / \mathrm{s}\right)$ & Flow rate & \\
gallon per minute $(\mathrm{gal} / \mathrm{min})$ & 0.02832 & cubic meter per second $\left(\mathrm{m}^{3} / \mathrm{s}\right)$ \\
\hline & 0.06309 & liter per second $(\mathrm{L} / \mathrm{s})$ \\
\hline miles per hour $\left(\mathrm{mi}^{2} / \mathrm{h}\right)$ & Velocity & \\
\hline
\end{tabular}

miles per hour (mi/h)

kilometers per hour $(\mathrm{km} / \mathrm{h})$

$\mathrm{mm}$ millimeter

$\mu \mathrm{m} \quad$ micrometer

Temperature in degrees Celsius $\left({ }^{\circ} \mathrm{C}\right)$ may be converted to degrees Fahrenheit $\left({ }^{\circ} \mathrm{F}\right)$ as follows:

${ }^{\circ} \mathrm{F}=\left(1.8 \times{ }^{\circ} \mathrm{C}\right)+32$

Temperature in degrees Fahrenheit $\left({ }^{\circ} \mathrm{F}\right)$ may be converted to degrees Celsius $\left({ }^{\circ} \mathrm{C}\right)$ as follows:

${ }^{\circ} \mathrm{C}=\left({ }^{\circ} \mathrm{F}-32\right) / 1.8$

Vertical coordinate information (elevation) is referenced to the North American Vertical Datum of 1988 (NAVD 88).

Horizontal coordinate information is referenced to the Universal Transverse Mercator North American Datum of 1983 (UTM NAD83).

Altitude, as used in this report, refers to distance above the vertical datum 


\title{
Thermal Imaging of the Waccasassa Bay Preserve: Image Acquisition and Processing
}

\author{
By Ellen Raabe and Elzbieta Bialkowska-Jelinska
}

\begin{abstract}
Thermal infrared (TIR) imagery was acquired along coastal Levy County, Florida, in March 2009 with the goal of identifying groundwater-discharge locations in Waccasassa Bay Preserve State Park (WBPSP). Groundwater discharge is thermally distinct in winter when Floridan aquifer temperature, $71-72{ }^{\circ} \mathrm{F}$, contrasts with the surrounding cold surface waters. Calibrated imagery was analyzed to assess temperature anomalies and related thermal traces. The influence of warm Gulf water and image artifacts on small features was successfully constrained by image evaluation in three separate zones: Creeks, Bay, and Gulf. Four levels of significant water-temperature anomalies were identified, and 488 sites of interest were mapped. Among the sites identified, at least 80 were determined to be associated with image artifacts and human activity, such as excavation pits and the Florida Barge Canal. Sites of interest were evaluated for geographic concentration and isolation. High site densities, indicating interconnectivity and prevailing flow, were located at Corrigan Reef, No. 4 Channel, Winzy Creek, Cow Creek, Withlacoochee River, and at excavation sites. In other areas, low to moderate site density indicates the presence of independent vents and unique flow paths. A directional distribution assessment of natural seep features produced a northwest trend closely matching the strike direction of regional faults. Naturally occurring seeps were located in karst ponds and tidal creeks, and several submerged sites were detected in Waccasassa River and Bay, representing the first documentation of submarine vents in the Waccasassa region. Drought conditions throughout the region placed constraints on positive feature identification. Low discharge or displacement by landward movement of saltwater may have reduced or reversed flow during this season. Approximately two-thirds of seep locations in the overlap between 2009 and 2005 TIR night imagery were positively re-identified in 2009. These results indicate a 33 percent chance of feature omission in the 2009 imagery. This assessment of seep location and distribution contributes to an understanding of the underlying geology, the role of fault and fracture patterns, and the presence of both interconnected and constrained flow paths in the region. The maps and evaluations will enhance Park management efforts, interpretation of Park resources, and increase understanding of the combined effects of land and water use on the coastal lowlands, estuarine habitats, and natural resources of WBPSP.
\end{abstract}




\section{Introduction}

The Floridan aquifer system (FAS) is at or near the land surface along the north and central Gulf Coast counties of Florida (Miller, 1990). The coastal lowland and estuarine ecosystems have evolved in concert with flow exiting the FAS at multiple discharge points across this region (Wolfe, 1990). The combined discharge from multiple coastal seeps can be substantial, and plays an important role in water quality, floral and faunal community composition and health, and coastal biogeochemistry (Cable and others, 1997). Local fisheries, clam aquaculture, ecotourism, and other economic enterprise may be positively or adversely impacted by changes in aquifer discharge and water quality. Discharge sites north and west of the Waccasassa Bay Preserve State Park (WBPSP) boundaries were identified using airborne thermal infrared (TIR) imagery in 2005 (Raabe and Bialkowska-Jelinska, 2007). Although a few large features are known, other discharge locations may be small, inaccessible, or obscured by vegetation or surface-water depth. Seep features are thermally distinct at night during winter when the temperature contrast is greatest between FAS discharge, $71-72^{\circ} \mathrm{F}$, and cooler surface waters. Because a small change in absolute temperature can greatly affect emitted energy, determination of the relative difference in emissive power between two adjacent surface-water bodies can facilitate identification of groundwater discharge into surface water. Similar technology has been used to identify previously unmapped vents and seep locations along the coast of Florida (Spechler, 1996; Davis, 2007; Raabe and Bialkowska-Jelinska, 2007).

The TIR imagery was processed to identify, map, and evaluate potential discharge sites, and to determine geographic relations between identified sites and the underlying geology and hydrology of the region. Under ideal circumstances, TIR image acquisition is conducted from January to early March and during pre-dawn hours. Due to delays, the imagery was acquired in late March 2009. Fortunately, the timing was coincident with a late cold spell with adequate temperature contrast between aquifer discharge and the cooler surface water. Background on regional geology, information on local water conditions, tides and weather, and the application of TIR in landscape analyses set the stage for understanding, interpreting, and applying information contained in TIR. The project focused on image analysis using standard image processing and Geographic Information System (GIS) techniques with innovative methods for landscape analysis. The primary objective, to identify temperature anomalies, was complimented with statistical analyses to establish confidence in site identification, and geographic analyses to establish links between surface features and geology. Field reconnaissance was conducted in conjunction with image acquisition to provide verification and preliminary in situ data for WBPSP. A secondary objective, to relate discharge rates with feature plumes identified in TIR imagery, was not feasible because of low groundwater levels in the region.

This project was a cooperative effort among the U.S. Geological Survey (USGS), Waccasassa Bay Preserve State Park (WBPSP), and the Florida Springs Initiative. A cooperative partnership among the WBPSP, USGS, Florida Geological Survey, CAMA-Big Bend Seagrasses Aquatic Preserve, and Florida Department of Agriculture and Consumer Services (DACS) assisted in this effort to draw on expertise and support from a range of agencies with limited fiscal resources. 


\section{Background}

\section{Study Area}

The study area includes the coastal lowlands of Levy County between Cedar Key and Yankeetown and the estuarine environments of Waccasassa and Withlacoochee Bays (fig. 1). The majority of Levy County lies within U.S. Department of Agriculture (USDA) plant hardiness Zone 8b, where the annual average minimum temperature range is $15-20^{\circ} \mathrm{F}$ (United States National Arboretum, 2009). Average annual precipitation is 58-62 in., with most rainfall occurring during the summer (Wolfe, 1990; Henry and others, 1994). The study area is part of the south Florida river-basin divide, where river stage and discharge are highest from September to October, and lowest from May to June (Heath and others, 1981).

The WBPSP is located along a rocky coastline with little or no wave energy and limited sediment supply (Vernon, 1951; Tanner, 1960; Hine and others, 1988). The underlying limestone can be exposed or covered with 1-6 ft of soil, sediment, or relict sand deposits (Coultas and Hsieh, 1997). The tidal range is about $3.3 \mathrm{ft}$, and relative sea level along this coast has risen 6-9 in. during the last 100 years (Coultas and Hsieh, 1997; Stumpf and Haines, 1998). Marine transgression, the process of marine waters overtaking dry land, is well documented in this region (Rogers, 1992; Williams and others, 1999; Raabe and others, 2004). An analysis of pre-settlement conditions along the Gulf Coast of Florida documented extensive forest-to-marsh conversion in the Waccasassa Bay region (Raabe and others, 2004).

Vernon (1951) described the marsh belt as the drowned portion of an irregular, rolling limestone shelf. The coastal area of Levy County consists of a low limestone plain with exposed rocks and relict sand dunes, and vegetated by hardwood forest, flatwoods, and swamps (Brooks, 1981). Habitats on WBPSP land include mesic flatwoods, sandhill, Cedar Key oak scrub, scrubby flatwoods, basin marsh and swamp, depression marsh, hydric hammock, and tidal marsh. Species and habitat details are discussed at length in several publications (Myers and Ewel, 1990; Wolfe, 1990; Coultas and Hsieh, 1997; Suwannee River Water Management District, 2007).

\section{Geology and Hydrologic Framework}

The WBPSP is located in the geomorphic Coastal Lowland Province and is almost entirely contained within the Silver Bluff marine terrace (Cooke, 1945; Healy, 1975; Denizman and Randazzo, 2000). WBPSP occupies a broad stretch of Coastal Swamp (White, 1970; Scott, 1992), where elevations are generally less than $5 \mathrm{ft}$ and rarely exceed $15 \mathrm{ft}$ (NAVD88). Fluctuations in sea level and freshwater flow have alternately exposed and flooded the Eocene Ocala Limestone of the region (Lane, 1994; Denizman and Randazzo, 2000). The Ocala Limestone is a carbonate rock derived from sediment deposition in a marine environment approximately 38 to 40 million years ago (Lane, 1994). Dissolution features in the underlying limestone, called paleokarst, are a result of chemical erosion over several cycles of rising and falling seas and freshwater flow, and are in part related to fracture and fault lines (Kindinger and others, 2000). Post-Jurassic tectonic activity produced normal fault lines in the Gulf region with a northwest-southeast strike pattern and down-to-the-coast movement (Beatty, 1977; Prowell, 1983; Prowell, 1988; fig. 2). Secondary fracture patterns contribute further to the structure and topography of the area. Fractures are often found parallel, or at right angles, to the major fault lines, as evidenced by the right angle of the Waccasassa embayment and sharply angled tributary intersections in the region (Vernon, 1951; fig. 2). 


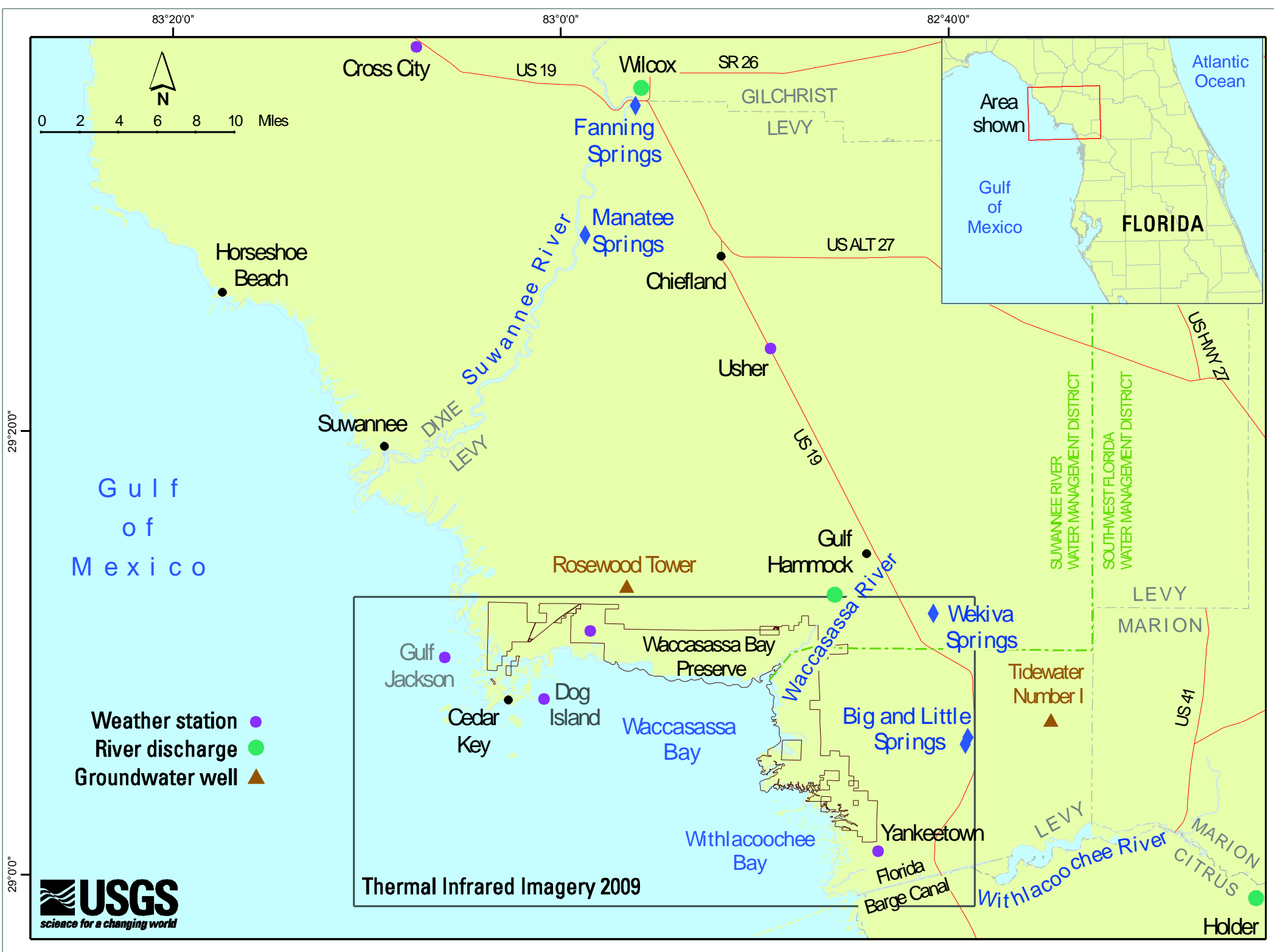

Figure 1. Waccasassa Bay Preserve thermal-imaging study area and surrounding region. 


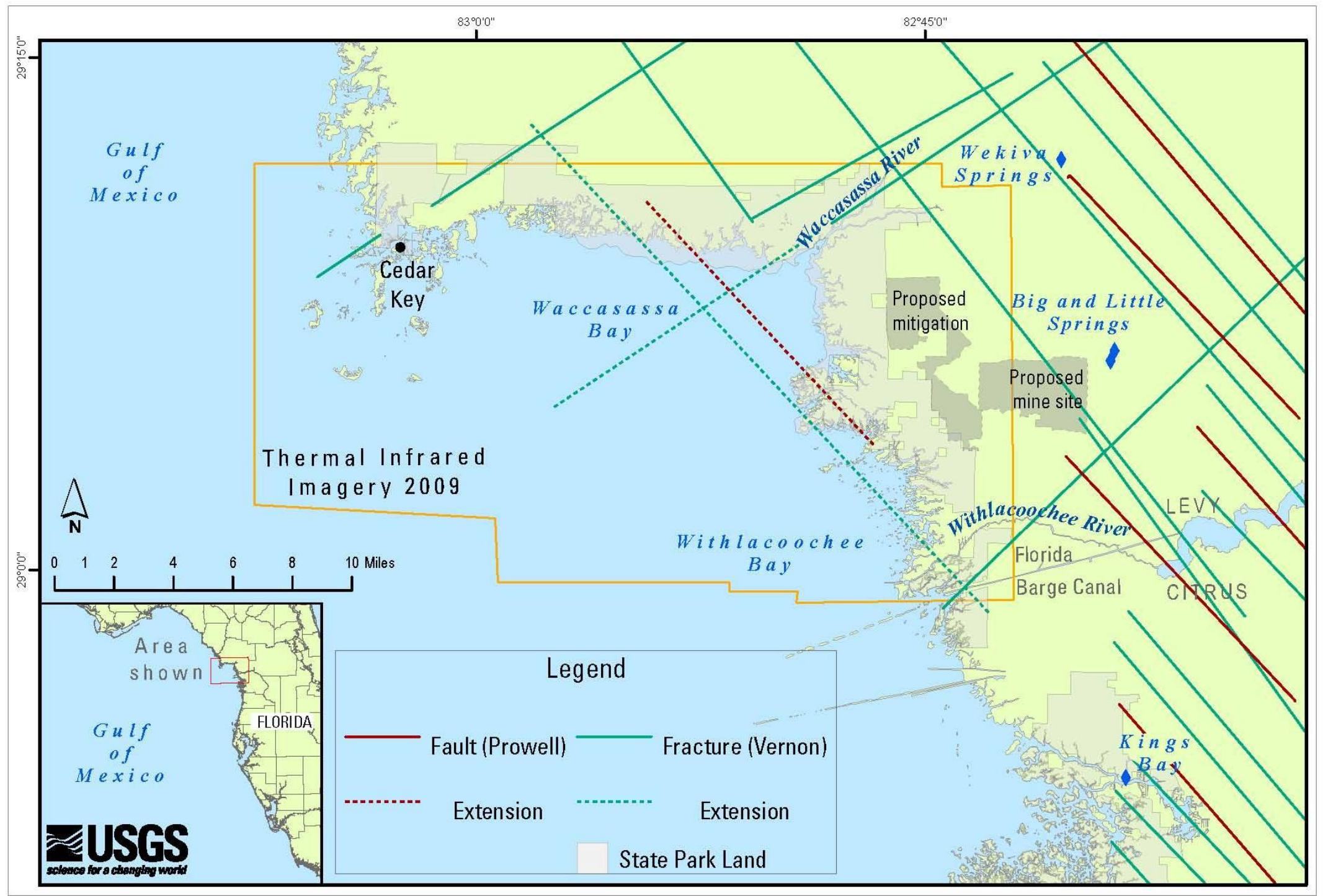

Figure 2. Study area showing relative location of springs, faults, and fracture lines. 
Over time, weathering and chemical erosion produced karst dissolution features, sinkholes, and conduits in the limestone. The limestone shelf can be pitted with linear or parallel expansion patterns, as noted in the Kelly Creek area (fig. 3), or displays a rolling, sheet-like surface as observed near Beetree Slough (fig. 4). Sinkholes in this region develop as depression features from the dissolution of surface rock. These hollows may fill with sand and clay particles, forming a seal on the bottom (Sinclair and Stewart, 1985). A combination of inherited structures and weathering has given rise to the rocky, pitted terrain (Denizman and Randazzo, 2000; Spechler, 2001; Fleury and others, 2007). The intermediate confining unit is virtually absent in this region, and the top of the Floridan aquifer system is at or close to land surface (Scott, 1992). The Ocala Limestone is an important aquifer-bearing unit, due to enhanced porosity, cavernous flow systems, and permeable composition (Scott, 1992; Coultas and Hsieh, 1997). Permeable layers and dissolution features facilitate flow along preferred pathways (Budd and Loizeaux, 1997; Kindinger and others, 2000; Tihansky, 2004).

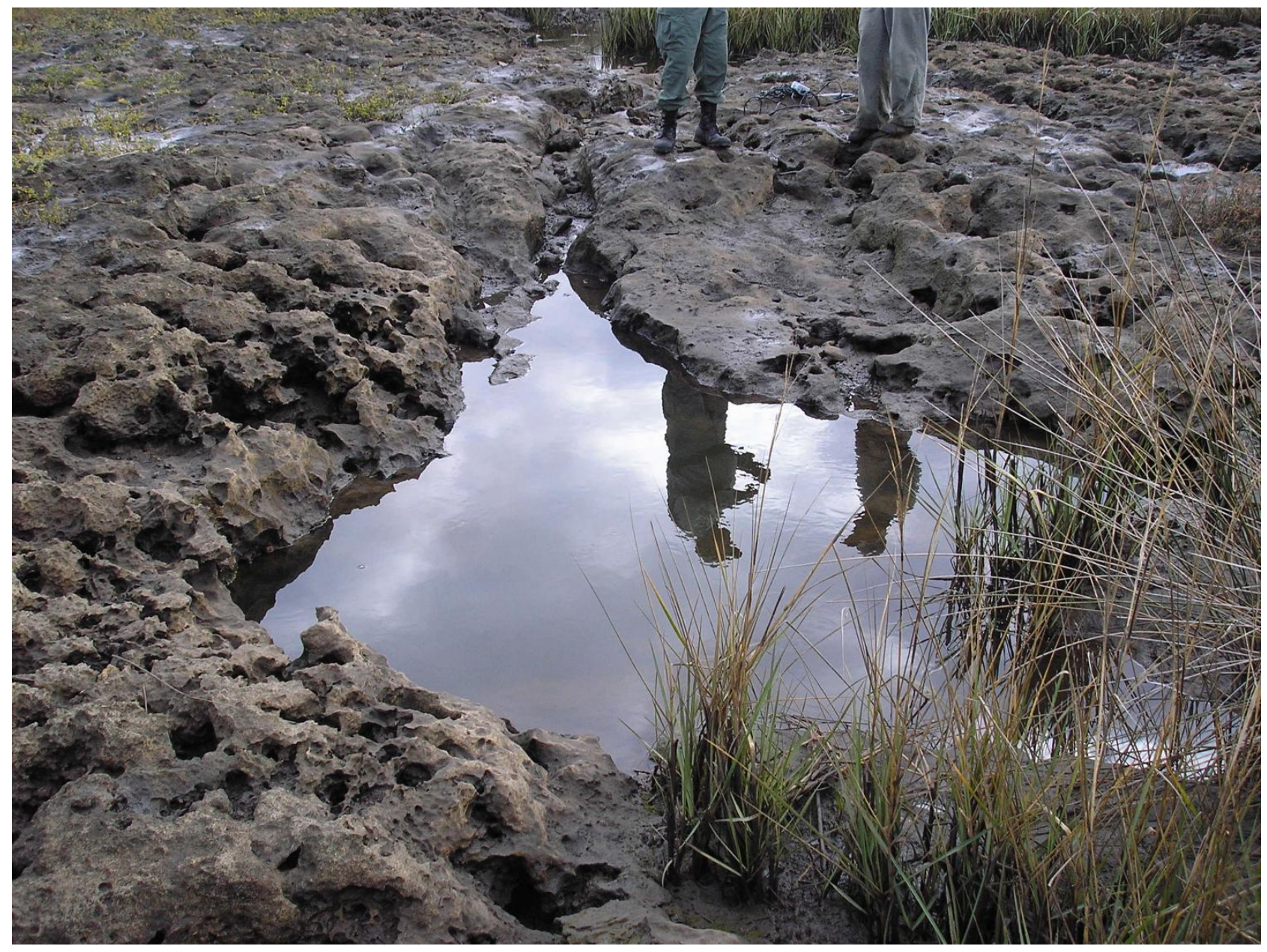

Figure 3. Limestone fractures and surface dissolution in WBPSP near Kelly Creek. 


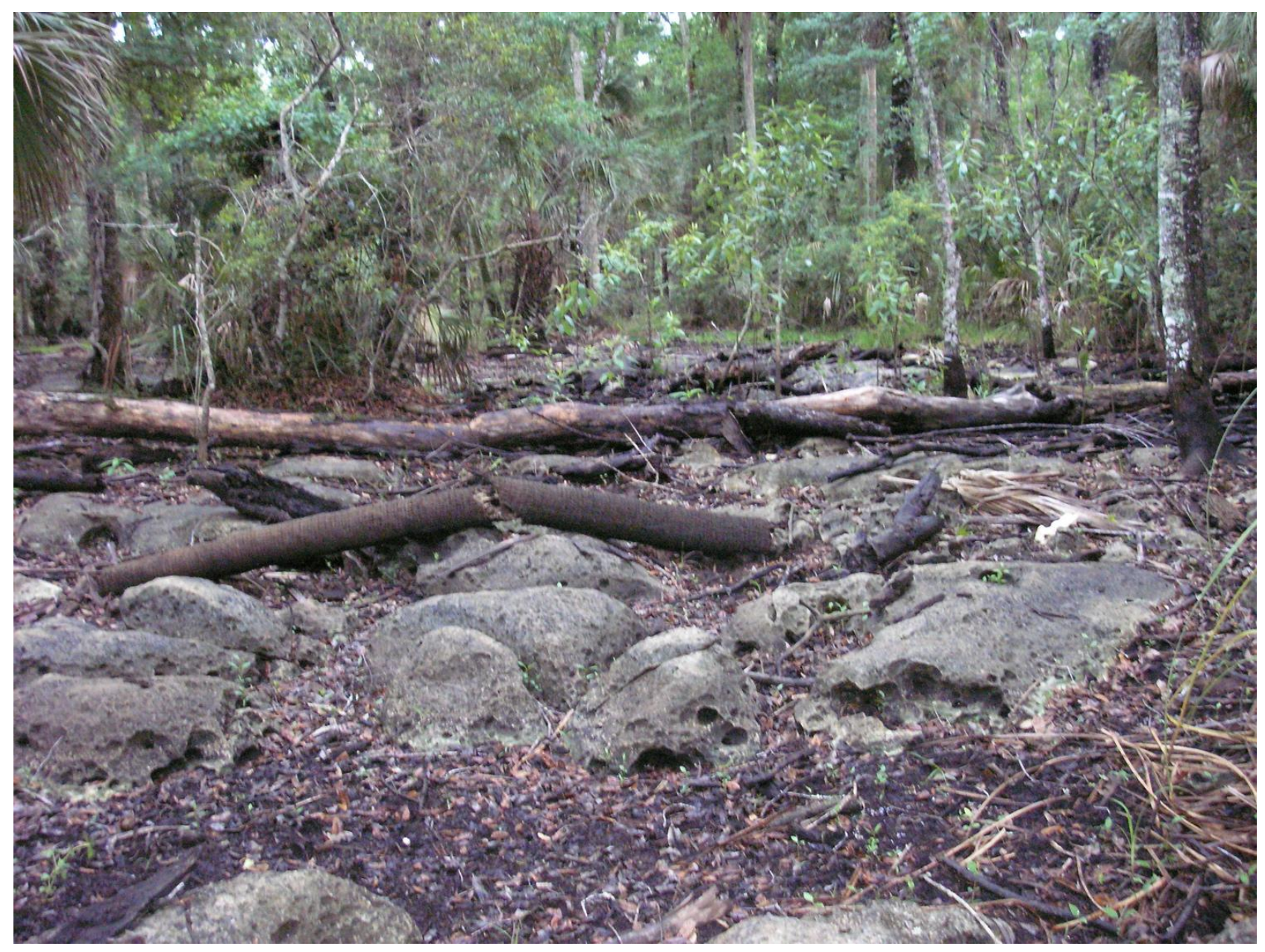

Figure 4. Rolling limestone plain and log debris in eastern region of WBPSP.

The FAS is under sufficient pressure, as it flows through the Ocala Limestone, to emerge or discharge through terrestrial springs such as Manatee, Big and Little, and Wekiva Springs (fig. 1). Primary porosity varies from high to low transmissivity within the sedimentary layers (facies) of the Ocala Limestone, each of which may conduct or occlude the flow of water (Loizeaux, 1995). Diagenesis, primarily in the form of dolomitic limestone, can reduce porosity in some areas, and porosity may be enhanced by secondary features such as fractures, fault lines, discontinuities, sinkholes, and dissolution conduits (Loizeaux, 1995; Tihansky, 2004). Groundwater and seawater move horizontally and vertically along preferential flow paths where change to the hydraulic gradient can produce mixing near the coast (Lewelling and others, 1998; Kindinger and others, 2000; Tihansky, 2004). Kohout (1977) hypothesized upwelling of recirculated and geothermally heated seawater along the central axis of the Floridan Plateau. More recent research supports the hypothesis of cyclic flow of seawater beneath the shelf and discharge through FAS exit points near the coast (Hughes and others, 2007).

The aquifer discharges to the surface through springs, submarine vents, and lesser-known fractures and seeps. Submarine vents have been identified on both the Atlantic and Gulf Coasts of Florida (Kohout and others, 1979; Lane, 2000; McClean, 2002; DeWitt, 2003; Scott and others, 2004). Lesser known features have been identified on the coast near the Suwannee River (Raabe and Bialkowska-Jelinska, 2007). Although discharge amount remains unknown, groundwater discharge to 
the coasts and estuaries is estimated to be substantial and plays an important role in estuarine health and productivity (Cable and others, 1996; Portnoy and others, 1998; Krest and others, 2000; Taniguchi and others, 2002; Burnett and others, 2003; Breier, 2006; Mulligan and Charette, 2008). Fluid exchange between fresh groundwater, submarine estuarine water, and meteoric waters involves complex biogeochemical loops and feedback systems (Moore, 1999).

Discharge volume is driven by the hydraulic-head gradient between the aquifer and the Gulf of Mexico and a water-density differential (Spechler, 1994; Spechler, 2001; Fleury and others, 2007). Flow near the coast is thus a function of sea level, tides, and groundwater levels in the aquifer (Coultas and Hsieh, 1997; Cable and others, 1997). Seawater flows inland through existing dissolution channels during periods of low groundwater levels in a process called reverse flow (Tihansky, 2004; Fleury and others, 2007). Groundwater was lowered up to $15 \mathrm{ft}$ in a $15-\mathrm{mi}^{2}$ region around the Florida Barge Canal in 1969, with a concomitant rise in the location of the freshwater/saltwater interface where groundwater levels had been lowered (Faulkner, 1973). Similar saltwater intrusion, with saltwater moving along preferential flow paths, was found in Pinellas County in association with groundwater levels lowered by drawdown from water-supply fields (Tihansky, 2004). Shaban and others (2005) describe reverse flows (from the sea to inland areas) where karst conduits became routes for seawater intrusion, notably in the vicinity of overexploitation of a coastal aquifer.

The saltwater/freshwater mixing zone is typically a zone of enhanced dissolution and increased karstification (Vernon, 1951; Denizman and Randazzo, 2000). As sea-level rise brings increased tidal flow across the Coastal Lowlands, the advancing seawater augments the dissolution process near the freshwater boundary (Romanov and Dreybrodt, 2006). The in situ mineralization of the substrate is enhanced where freshwater and seawater mix, thus enlarging and extending existing karst features and flow routes along this mobile boundary (Singurindy and others, 2004; Romanov and Dreybrodt, 2006). Due to the non-stationary distribution of the saltwater/freshwater interface, the region of high dissolution can be extensive. Complex biogeochemical processes take place at the boundary, where chemical constituents and suitable microorganisms produce a series of feedback loops until equilibrium is reached (Moore, 1999). Limestone resources in Florida have historically been extracted for roads and construction purposes (Lane, 1994). Currently, a proposal for an extraction mine is being reviewed by the State of Florida (Federal Register, 2008). The proposed area is to the east of the WBPSP in southern Levy County (fig. 2).

\section{Application of Thermal Infrared Imagery in Landscape Analysis}

TIR imagery from satellite, airborne, and ground platform sensors has been directed toward a variety of scientific applications. Researchers have used TIR to identify thermal refugia for fish in streambeds (Torgersen and others, 1995), to monitor stream temperature (Faux and others, 2001), to identify hot spots and assist fire management (Beck, 2004), to identify animals and conduct survey counts (Havens and Sharp, 1998; Focardi and others, 2001), and to "fingerprint" cave entrances (Thompson and Marvin, 2006). The location, size, and source of polluted-water bodies have been identified with TIR (Portnoy and others, 1998; Mustard and others, 1999; Stockton, 2004). Heat islands in urban areas have been detected by contrasting day and night TIR (Lo and others, 1997). TIR imagery can be applied to a variety of ecological processes (Quattrochi and Luvall, 1999). A broad and successful application of TIR has been the detection of groundwater discharge into surface waters.

The use of heat as a groundwater tracer can be traced to mid-20th century researchers (Anderson, 2005). The premise behind comparative temperature analysis is to exploit existing temperature differences between surface water and groundwater at certain times of year. As early as 1975, researchers used airborne thermal sensors to detect groundwater seeps unidentifiable with color- 
infrared imagery (Dalsted and others, 1979). Researchers used satellite thermal bands to document submarine groundwater discharge off the coast of Florida (Kohout and others, 1979). Since the 1970s, both satellite and airborne TIR have been used to detect groundwater discharge, either warmer or cooler than the surrounding surface water, by successfully detecting the contrast in water temperature from different sources (Spechler, 1996; Nuttle and Portnoy, 1992; Portnoy and others, 1998; McClean, 2002; Taniguchi and others, 2002; Watershed Sciences, 2002, 2004; Tcherepanov and others, 2005; Davis, 2007; Raabe and Bialkowska-Jelinska, 2007). TIR has been used to map, detect, and model groundwater in estuaries and coastal systems worldwide (Land and Paull, 2001; Bayari and Kurttas, 2002; Astaras and Oikonomidis, 2006; Danielescu and others, 2009). TIR imagery of the Lower Suwannee River was acquired and analyzed in March 2005 (Raabe and Bialkowska-Jelinska, 2007). The 2005 airborne TIR imagery captured temperature contrasts of $4-10^{\circ} \mathrm{F}$ between ambient nighttime surface-water temperature and aquifer discharge from numerous small and previously unknown seeps in the region.

Quantification and modeling of groundwater discharge to the coast are fraught with difficulties, not the least of which is insufficient data. The importance of groundwater to coastal ecosystems may be substantial and was not recognized until recently (Cable and others, 1996; Mulligan and Charette, 2008). Urban development and water demands have peaked interest in the capture and use of water discharging through submarine spring vents off the coast of Florida (DeWitt, 2003). The effect of lowered coastal groundwater on water quality and supply has been documented in Florida (Faulkner, 1973; Turner and others, 1997; Rudloe, 1998; Burnett and others, 2000; Tihansky, 2004). Coastal groundwater discharge is increasingly important as concerns for fisheries and estuarine health compete with increased water demands by urban and industrial developments, decreased freshwater flow to the coast, altered water quality, and sea-level rise.

\section{Diurnal Energy Fluctuation}

To understand the application of TIR in the detection seeps, a fundamental knowledge of thermal infrared radiation and the differences between materials typically found in the landscape is needed. Energy exchange between the Earth's surface and the atmosphere follows a diurnal cycle, depending on the reflection, emission (radiant flux), and thermal-inertia properties of each material (fig. 5; Drury, 2001). Generally, materials exposed to sunlight absorb heat during the day and release energy at nightfall. The apparent thermal inertia of water translates to slow heating during the day and slow release of energy during nighttime hours. Vegetation follows a similar pattern due to the high moisture content in some plants. Absorption of heat and subsequent energy emission is subdued in wet or saturated soils compared to water (fig. 5; Sabins, 1987; Drury, 2001). Wet soils may be $9{ }^{\circ} \mathrm{F}$ lower than dry soils during the day (VeriMap, 2009a), which can translate to substantially lower temperatures at night.

Unlike reflected energy, thermal infrared sensors measure the energy emitted from objects in the thermal infrared region of the spectrum, with wavelengths that fall between those of visible light and microwave. Use of a TIR sensor during the day presents a complex set of issues associated with sunlight, including air temperature, solar gain (increased energy from objects absorbing solar energy), and temperature differences associated with aspect and shadow (Lillesand and others, 1994). Daytime TIR missions failed to detect groundwater discharge to the Peace River (Lewelling and others, 1998), and application of daytime satellite thermal bands generated confusion between aquifer discharge and solar gain of exposed sandbars (McClean, 2002).

The optimal time for groundwater TIR application is at night, preferably in predawn hours, when the temperatures of surface features are lowest (Chudnovsky and others, 2004). During this time, landscape features will display greater contrast with surface water and unique thermal features such as 
seeps. The acquisition of thermal infrared imagery during the predawn hours ensures that most materials, including water, have released stored energy and have reached a state of equilibrium with the surrounding air temperature. Additionally, image acquisition during cold weather ensures that less heating occurred during the day and surface features quickly reach equilibrium with colder air temperatures at night.

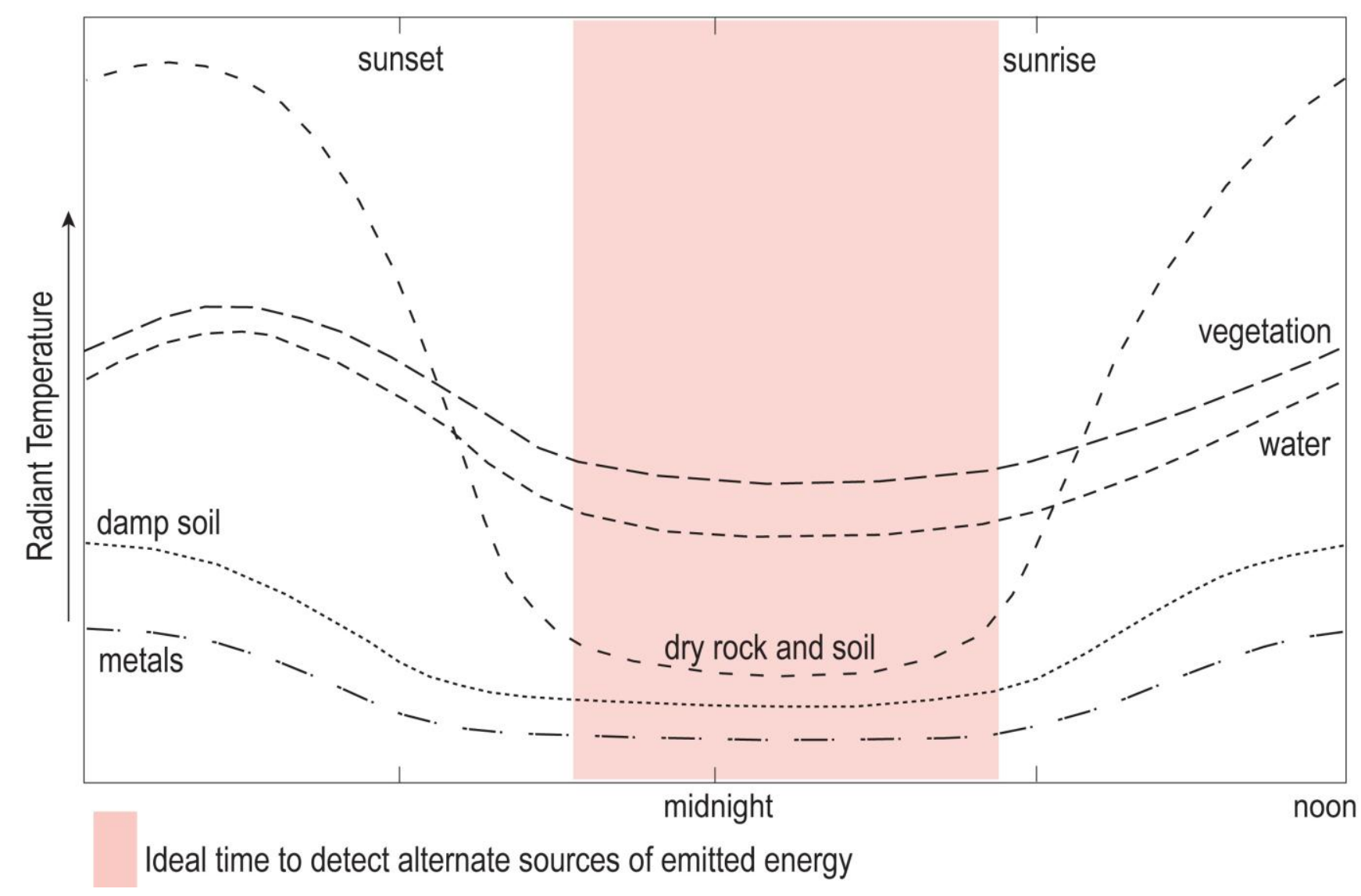

Figure 5. Diurnal cycle of heating and cooling (adapted from Drury, 2001, used with permission).

A sufficient number of studies has been conducted comparing day and night thermal infrared imagery to understand the emissive and thermal-inertia properties of most materials found on the Earth's surface (Short, 2009). The complex relation between soil composition and moisture content has been explored (Mira and others, 2007), and the role of vegetation in moderating diurnal heating and cooling processes was exemplified by tree canopies reducing the urban heat-island effect (Lo and others, 1997). Wind, rain, and cloud cover also influence the diurnal process and the contrast obtained in thermal imagery (Lillesand and others, 1994). Thermal infrared radiation is a combination of emitted energy, atmospheric absorption, and atmospheric reemission. Water is a particularly strong emitter of TIR. It is generally accepted, due to error sources and variations, that differences of $0.8{ }^{\circ} \mathrm{F}$ or less are associated with noise level (from sensors and reflection), unless the difference is associated with a particular thermal process, such as diffusion from a point source, or the location of a mixing zone between two surface-water bodies. The goal is to achieve a temperature difference of several degrees Fahrenheit between ambient surface water and groundwater discharge temperature for detection confidence. In the application of TIR to groundwater research, image acquisition is a balancing act to 
obtain (1) the best contrast between surface and groundwater, (2) sufficient contrast between surface water and surrounding landscape features, and (3) correct timing for tides and regional water levels.

\section{Data Acquisition}

Approximately 300,000 acres of TIR imagery were collected in east/west flight lines, $2.9 \mathrm{mi}$ wide with an image resolution of $5 \mathrm{ft}$. Flights coincided with low to rising tides from 2:20 a.m. to 4:05 a.m. on March 30, 2009, within the predawn window for optimal temperature contrast. A Thermal StepStare array was employed with the Mitsubishi SW thermal sensor on a Cessna 310 twin-engine aircraft with a flight speed of $184 \mathrm{mi} / \mathrm{h}$ and an altitude of $12,500 \mathrm{ft}$. The $640 \times 480$ focal plane array with Sterling cycle cooler has a thermal response of $1.2 \mu \mathrm{m}$ to $5.9 \mu \mathrm{m}$, a focal length of $50 \mathrm{~mm}$, and a 51 degree Field of View (5-image sweep). The Inertial Reference Gyro System was coupled to a real-time differential GPS satellite positioning system that provided 1.6-ft x, y, z positioning to the aircraft, eliminating the need for GPS ground stations for final Imagery Geometry Solution (VeriMap, 2009b).

Imagery was mosaicked to a common planar-projected coordinate system and georectified (VeriMap, 2009b). Temperature calibration was conducted for actual temperatures using data from realtime data sondes near Cedar Key (Florida Dept. Agriculture and Consumer Serv., 2009; fig. 1). Image data (UTM NAD 83 Zone 17) at 6.5-ft resolution were delivered to the USGS for further processing. A temperature conversion table was used to evaluate temperature from image values with a range of 11255. Useable imagery covered approximately 220,000 acres in Levy County, and sporadic image coverage in the area of flight turns captured the area around Big and Little Springs.

\section{Weather and Climatic Conditions during Data Acquisition}

The WBPSP lies between Yankeetown to the south, Gulf Hammock to the east and north, and Cedar Key to the west in Levy County, Florida (fig. 1). Weather records in the area were obtained from the Southeast Regional Climate Center (SERCC, 2009) and a weather gage at the WBPSP office (fig. 1). Data sondes operated by Florida Department of Agriculture and Consumer Services (2009) provided real-time temperature and salinity readings in surface water east and west of Cedar Key (fig. 1; Florida Dept. Agriculture and Consumer Services, 2009).

Temperature, Precipitation, and Wind

The imagery was acquired during predawn hours on March 30, 2009, to obtain the desired temperature contrast. Temperatures in the region had been warming in weeks prior to data acquisition, accompanied by increased water temperatures in the Gulf. However, regional temperatures dropped during the days prior to the flight and continued to decrease between 10:00 p.m. March 29 and the early hours of March 30 by as much as $16^{\circ} \mathrm{F}$ (table 1). Low night air temperature ranged from low to high 40s. Winds were calm or below $2 \mathrm{mi} / \mathrm{h}$ with occasional gusts to $12 \mathrm{mi} / \mathrm{h}$ out of the NW. WBPSP station reported 0.62 in. of rain on March 29 and no precipitation on March 30. Air and water temperatures for stations at and near WBPSP are shown in table 1. 
Table 1. Nearby temperature and salinity records for March 29-30, 2009. [--, no data; ppt, part per thousand, WBPSP, Waccasassa Bay Preserve State Park]

\begin{tabular}{|c|c|c|c|}
\hline \multirow{2}{*}{ Station } & March 2910 p.m. & March 306 a.m. & \multirow{2}{*}{ March 30} \\
\hline & air temperature $\left({ }^{\circ} \mathrm{F}\right)$ & air temperature $\left({ }^{\circ} \mathrm{F}\right)$ & \\
\hline Cross City $^{1}$ & 57 & 41 & -- \\
\hline Yankeetown ${ }^{I}$ & 60 & 45 & -- \\
\hline WBPSP Station $^{2}$ & $\sim 54^{*}$ & 47 & -- \\
\hline Station & water temperature ( $\left.{ }^{\circ} \mathrm{F}\right)$ & water temperature $\left({ }^{\circ} \mathrm{F}\right)$ & Salinity \\
\hline Dog Island $^{3}$ & 71 & 66 & $28-29 \mathrm{ppt}$ \\
\hline Gulf Jackson $^{3}$ & 71 & 68 & $25-28 \mathrm{ppt}$ \\
\hline
\end{tabular}

${ }^{1}$ Data retrieved from the Southeast Regional Climate Center website.

${ }^{2}$ Data retrieved from the WBPSP Station.

${ }^{3}$ Data retrieved from the Florida DACS data sondes.

\section{Regional Hydrologic Conditions}

The study area straddles the boundary between two State Water Management Districts (WMDs): Suwannee River Water Management District (SRWMD) and the Southwest Florida Water Management District (SWFWMD, fig. 1). Data on hydrologic conditions in Levy County was assembled from reports by each WMD and from Federal resources, such as the National Oceanic and Atmospheric Administration (NOAA) and USGS. The SRWMD (2009a) reported declining groundwater levels, lake levels, springflow, streamflow, and rainfall in February. The central portion of Levy County, concentrated in the Waccasassa River watershed, showed extremely low (less than 10th percentile) groundwater levels in February (SRWMD, 2009a). Drought conditions continued into March with below-normal rainfall and streamflow below the 10th percentile (SRWMD, 2009b; fig. 6).

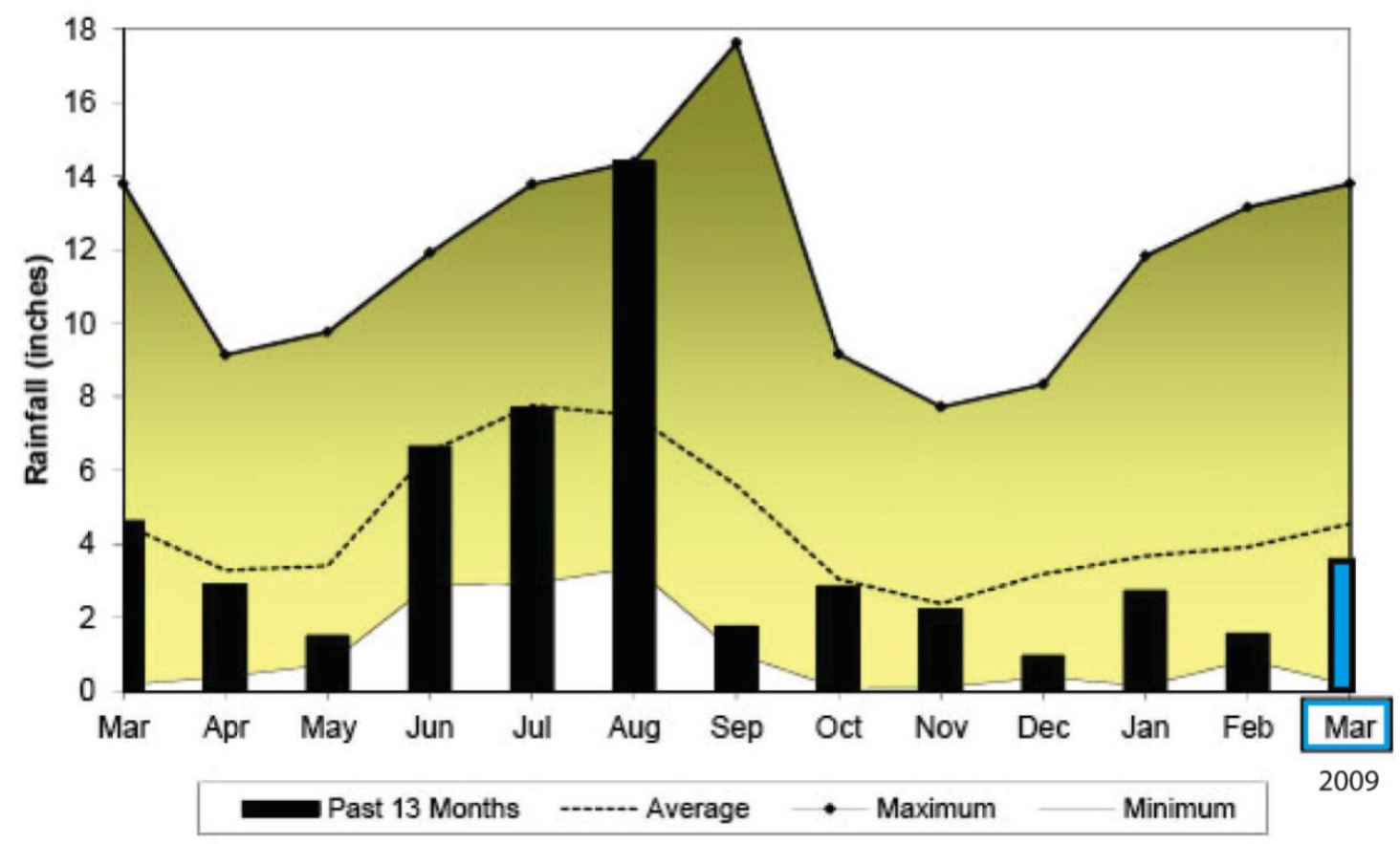

Figure 6. SRWMD rainfall record, March 2008-March 2009, showing March 2009 highlighted in blue. 
Figure 6 shows six months of below-average rainfall prior to data acquisition in March 2009 (adapted from SRWMD, 2009b). Groundwater levels were down by 69 percent from February, and were considered to be extremely low, with 12 record monthly lows observed (SRWMD, 2009b). Low streamflow and groundwater levels can result in diminished discharge at springs and seeps along the coast. Data acquisition occurred during the dry season and during a prolonged drought.

Groundwater levels, springflow, streamflow, and rainfall were all below normal for Levy County in March 2009 (SWFWMD, 2009). This region experienced a drier than normal March, with less than 50 percent of normal rainfall and severe-drought conditions. SWFWMD (2009) reported lake levels $5.5 \mathrm{ft}$ below base of the annual normal range in Levy County. Streamflow in Levy County was below the normal range, regionally in the lower 5th percentile and substantially lower than March 2008 by $217 \mathrm{ft}^{3} / \mathrm{s}$. Springflow in the region was lower by $155 \mathrm{ft}^{3} / \mathrm{s}$ and below the 10th percentile for period of record and represented a decrease from February of $74 \mathrm{ft}^{3} / \mathrm{s}$. Regional groundwater had decreased by March, and levels were at the 16th percentile, $2.04 \mathrm{ft}$ below the normal range. The weekly Aquifer Resource Index (ARI) level was $-0.77 \mathrm{ft}$ relative to the bottom of the normal range at the time of data acquisition in Levy County (SWFWMD, 2009).

Conditions in Levy County were notably different during the years prior to data collection in March 2009 than the years prior to data collection in March 2005 (Raabe and Bialkowska-Jelinska, 2007). Figure 7 illustrates annual rainfall totals at Usher Tower in Levy County and indicates conditions preceding 2005 and 2009 data acquisition (National Climate Data Center, 2009).

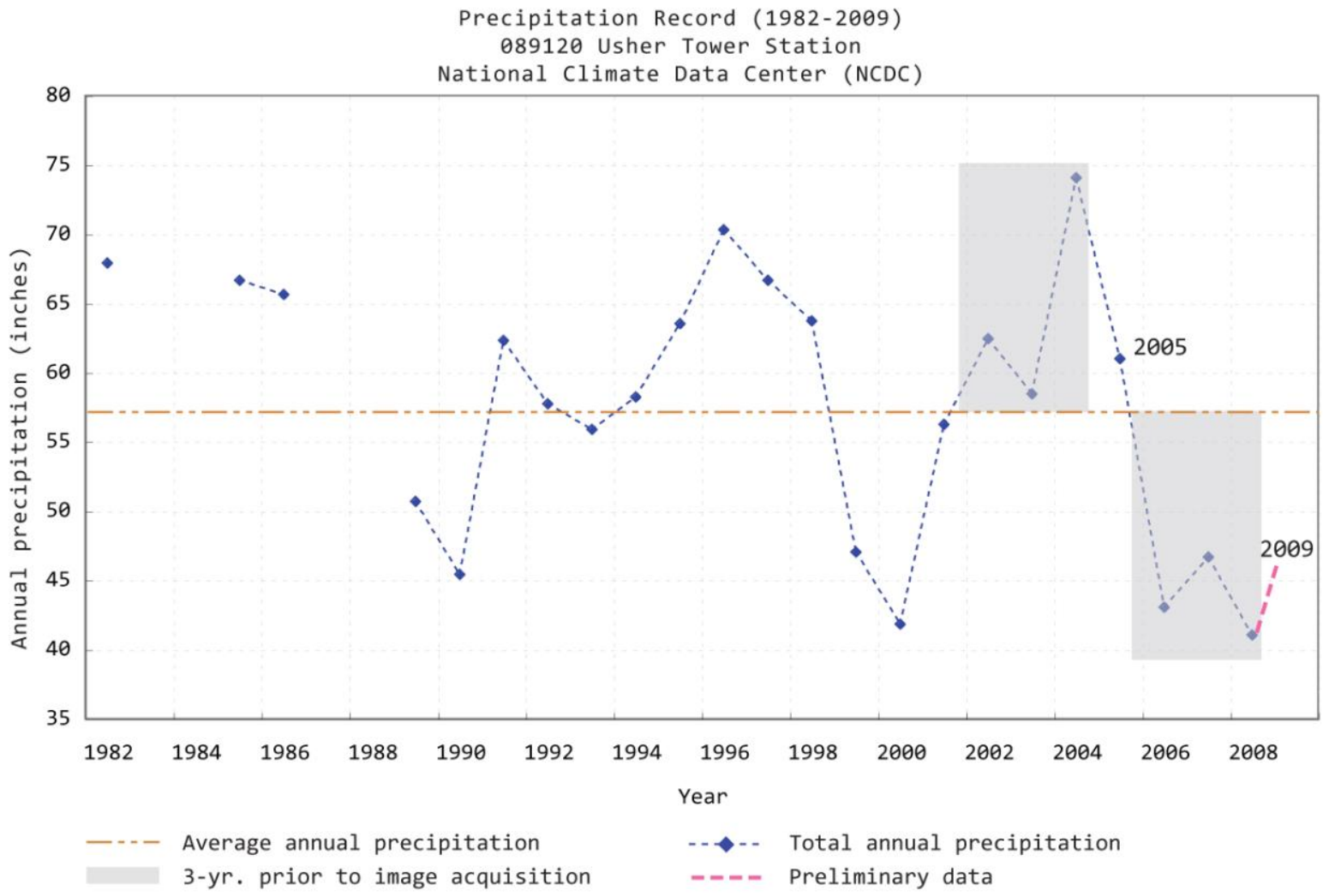

Figure 7. Usher Tower rainfall record 1982-2008. 
Annual rainfall totals in the 3 years preceding 2005 were at or above average. Annual rainfall totals were markedly below average in the 3 years preceding 2009 data acquisition. The Palmer Drought Severity Index ranged from normal to moist conditions in Levy County in the year prior to March 2005 (NOAA, 2009). The same index ranged from moderate to severe-drought conditions in Levy County prior to data acquisition in March 2009 (NOAA, 2009).

River discharge and groundwater conditions around Levy County were below average in the seasons leading up to the 2009 data collection. River discharge records for three Levy County locations are shown in figure 8a,b, and c (National Water Information System, 2009). Figure 8 illustrates the relatively low river discharge(s) observed in Levy County prior to and during data collection in 2009 as compared to 2005. Suwannee at Wilcox discharge had been below the mean daily statistic for 2 years or more (fig. 8a). Discharge for Waccasassa at Gulf Hammock remained below mean daily discharge for the prior 4 years, except for occasional pulses (fig. 8b). Discharge for Withlacoochee River near Holder was markedly below the mean daily statistic since 2006 (fig. 8c).

Groundwater levels for Levy County at Rosewood Tower and Tidewater Number I are shown in figure 9a, b (National Water Information System, 2009). Marks indicate groundwater level recordings coincident to data collection efforts in 2005 and 2009. Groundwater level in 2009 was the lowest ever recorded at Rosewood and in the lower range of values for Tidewater I. Groundwater levels were substantially lower in 2009 than in 2005 at each well.

a.

\section{₹USGS}

USGS 02323500 SUWANNEE RIVER NEAR WILCOX, FLA.

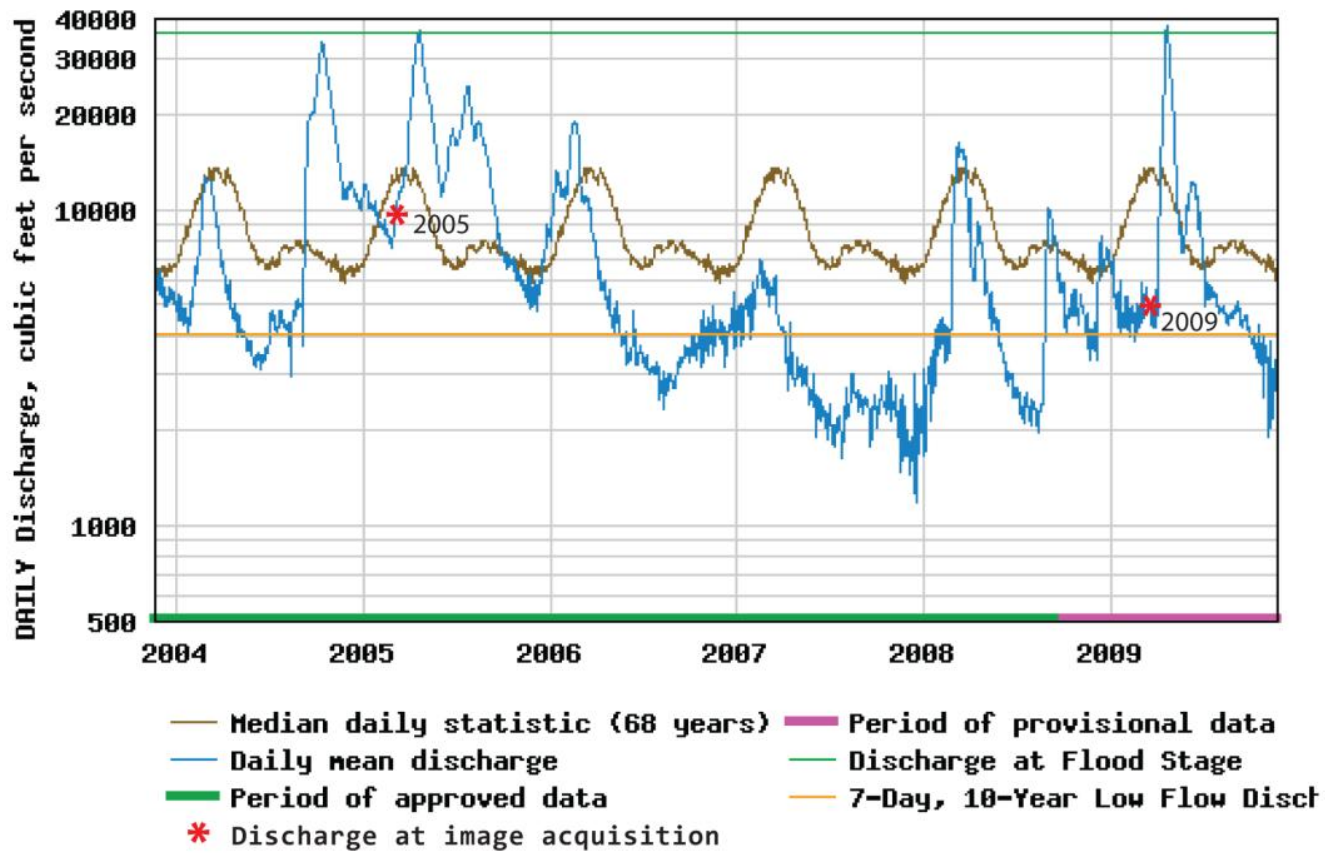

Figure 8. River discharge: a. Suwannee River near Wilcox. 
b.

USGS 02313700 WACCASASSA RIVER NR GULF HAMMOCK, FLA.

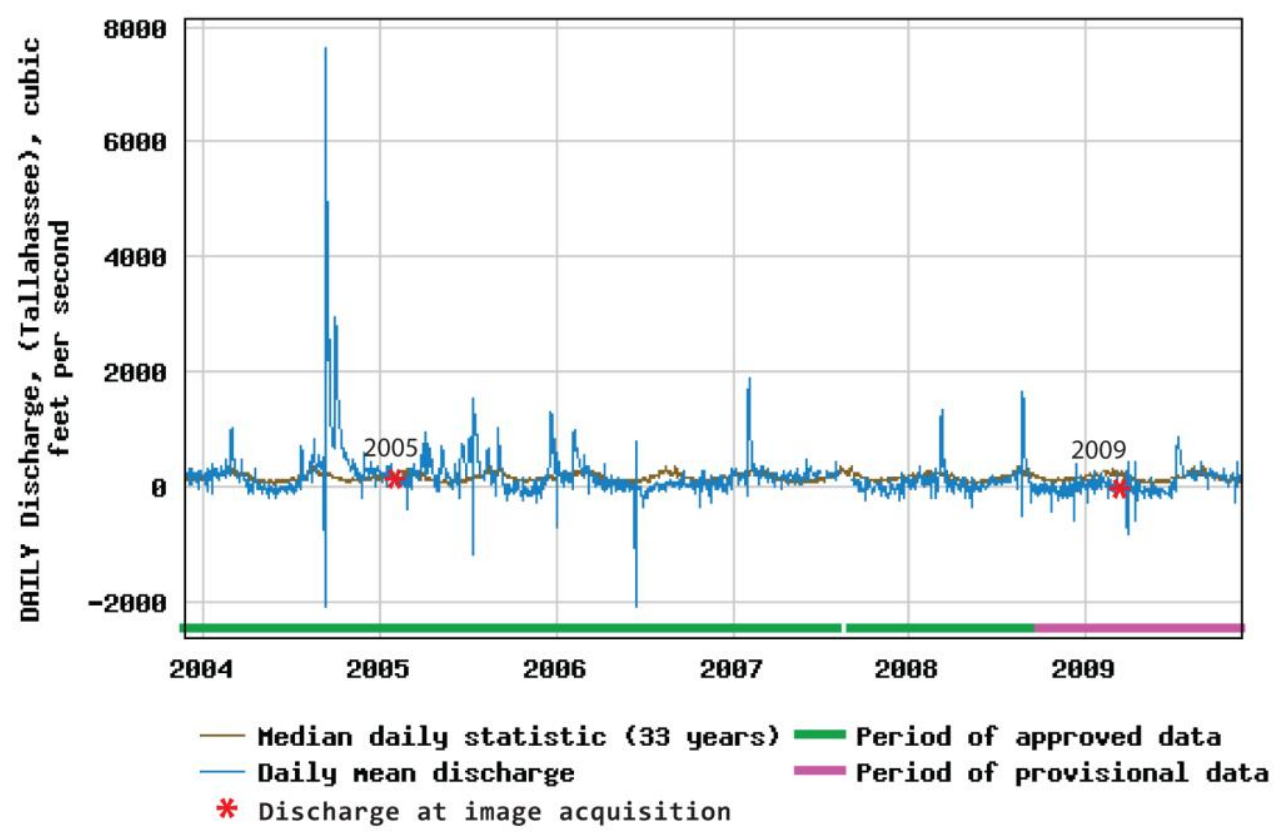

c.

\section{\#USGS}

USGS 02313000 WITHLACOOCHEE RIVER NEAR HOLDER, FL

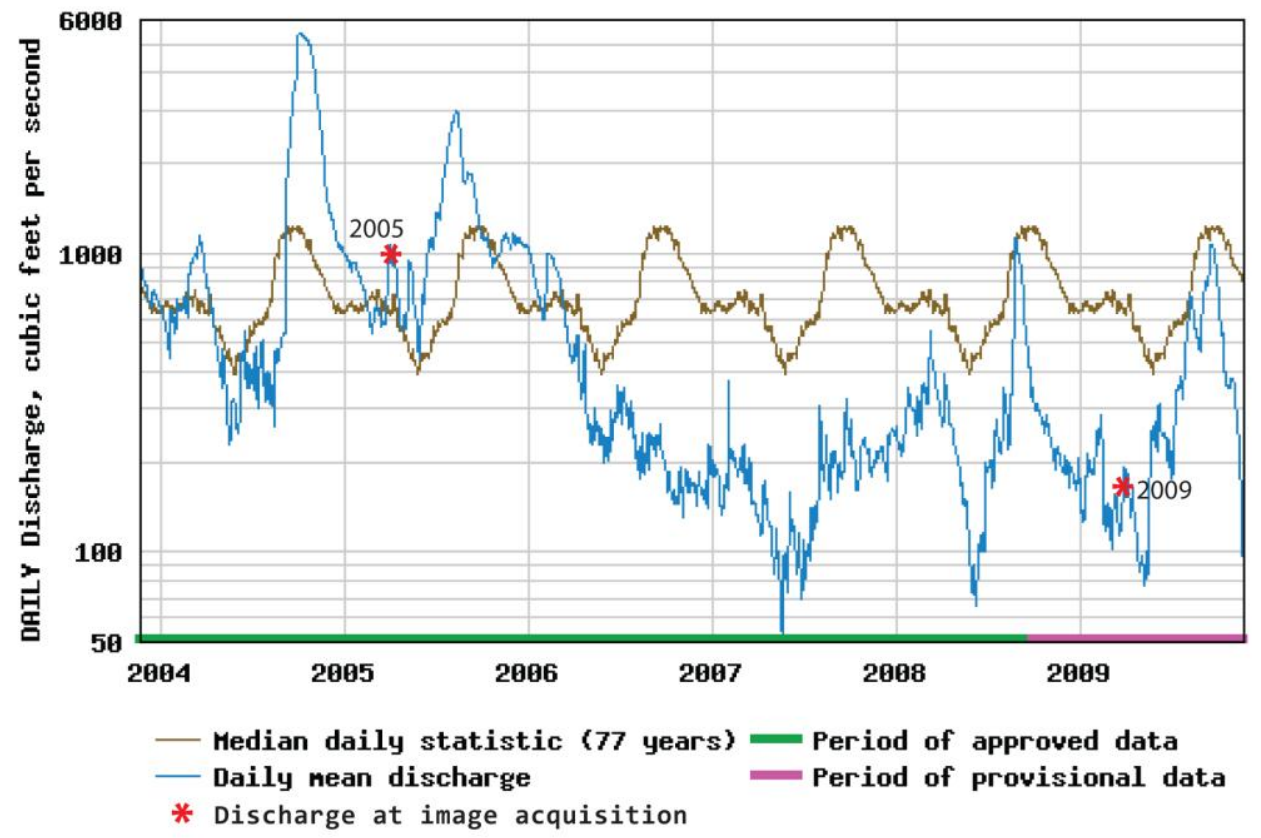

Figure 8. River discharge: b. Waccasassa River near Gulf Hammock, c Withlacoochee River near Holder. 
a). Rosewood Tower Well

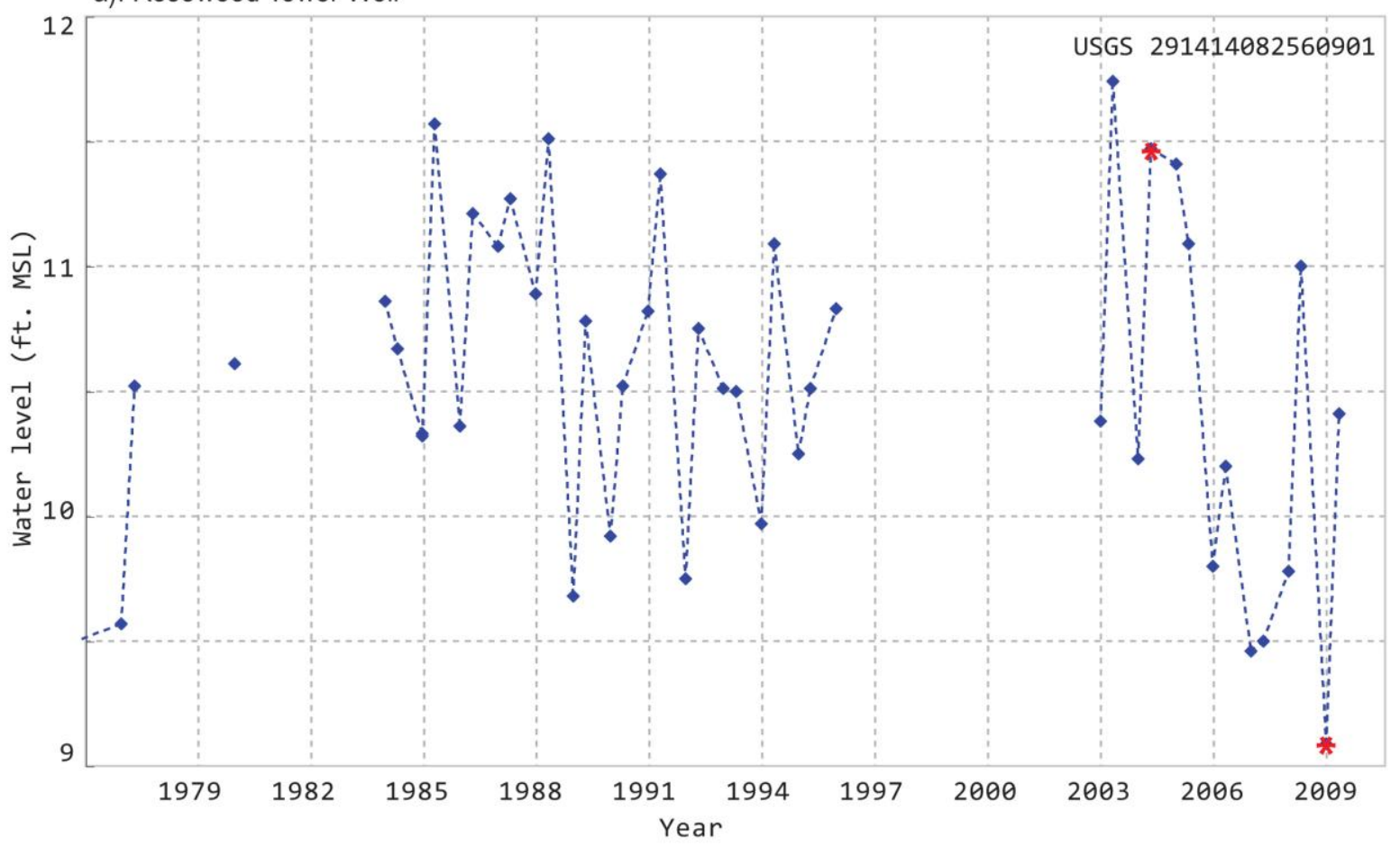

b). Tidewater Well Number 1

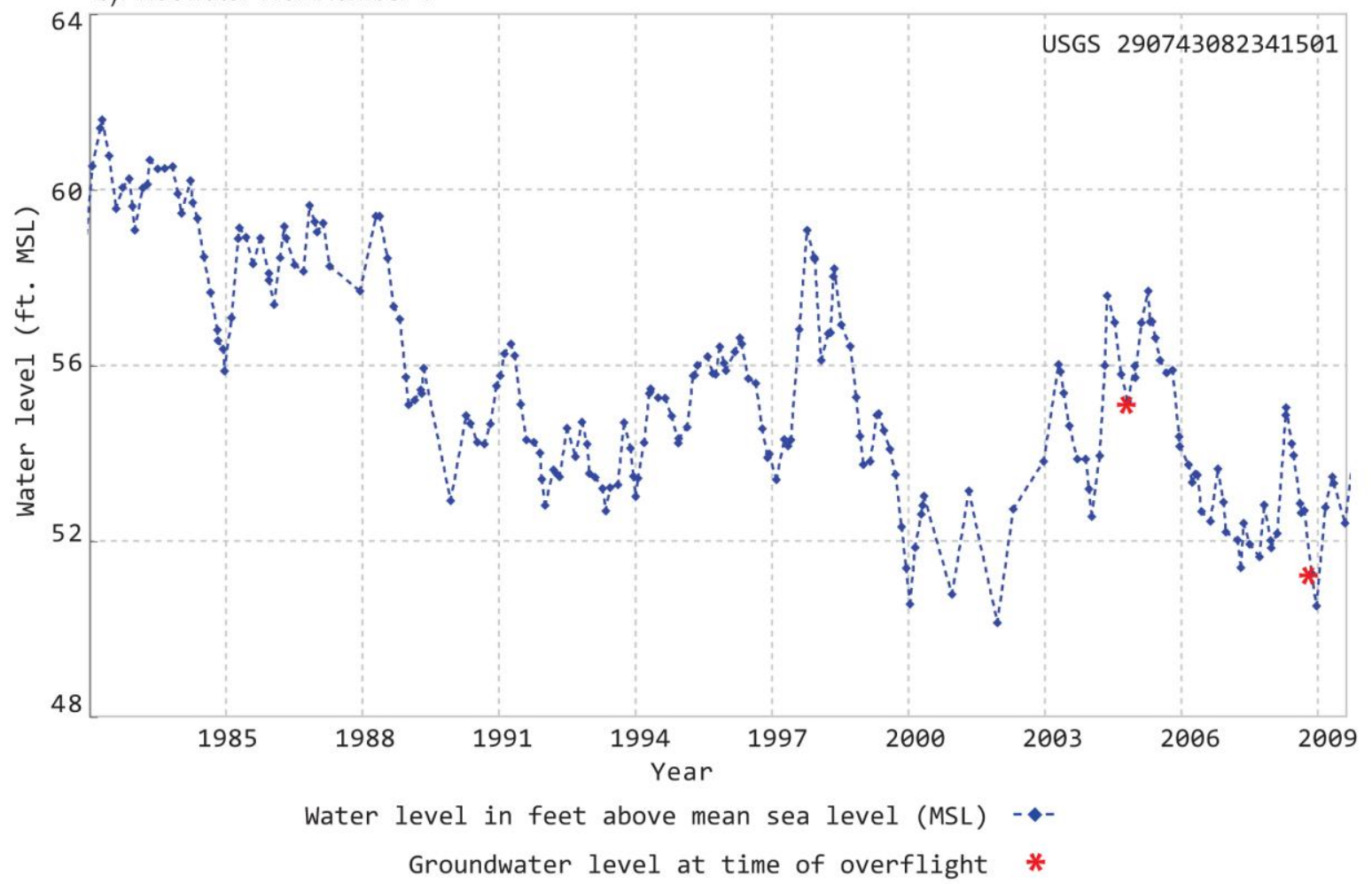

Figure 9. Groundwater levels in USGS observation wells: a. Rosewood Tower, b. Tidewater Well Number I. 
Tides play a role in the behavior of seeps in coastal regions. A low tide, below mean sea level (MSL), equivalent to $-0.23 \mathrm{ft}$. NAVD88, is ideal for identification of smaller features, especially those submerged along the coast because shallow surface water allows the feature to be observed directly, and there is less chance of reverse flow with incoming tide. The imagery was acquired predawn, when both air and water temperatures were expected to be at their lowest for the night. This time period coincided with the beginning of a rising tide. It was determined that the increased temperature contrast predawn took priority in the identification of thermal anomalies due to the early spring weather. It was recognized that the rising tide could mask some features in open water; however, tides in this region are generally wind-driven, showing time lags and variations from predicted water levels during wind events. A time lag for tides in the tidal creeks has been documented on the order of up to 2 hours for both incoming and outgoing tides (Raabe and others, 2007). Although there was some risk that incoming tides could overwhelm features in open water, it was expected that tidal effects, such as reverse flow, would be marginal on features in creeks due to timing lag of tides moving up creek. Predicted tides showed data acquisition starting at a low tide, well-below MSL, and ending with an incoming tide. Actual tide levels were slightly later and less pronounced than predicted (National Ocean Service, 2009; fig. 10). Data acquisition began at a low tide and rose $1.53 \mathrm{ft}$. to $0.1 \mathrm{ft}$. (NAVD88) by end of data acquisition.

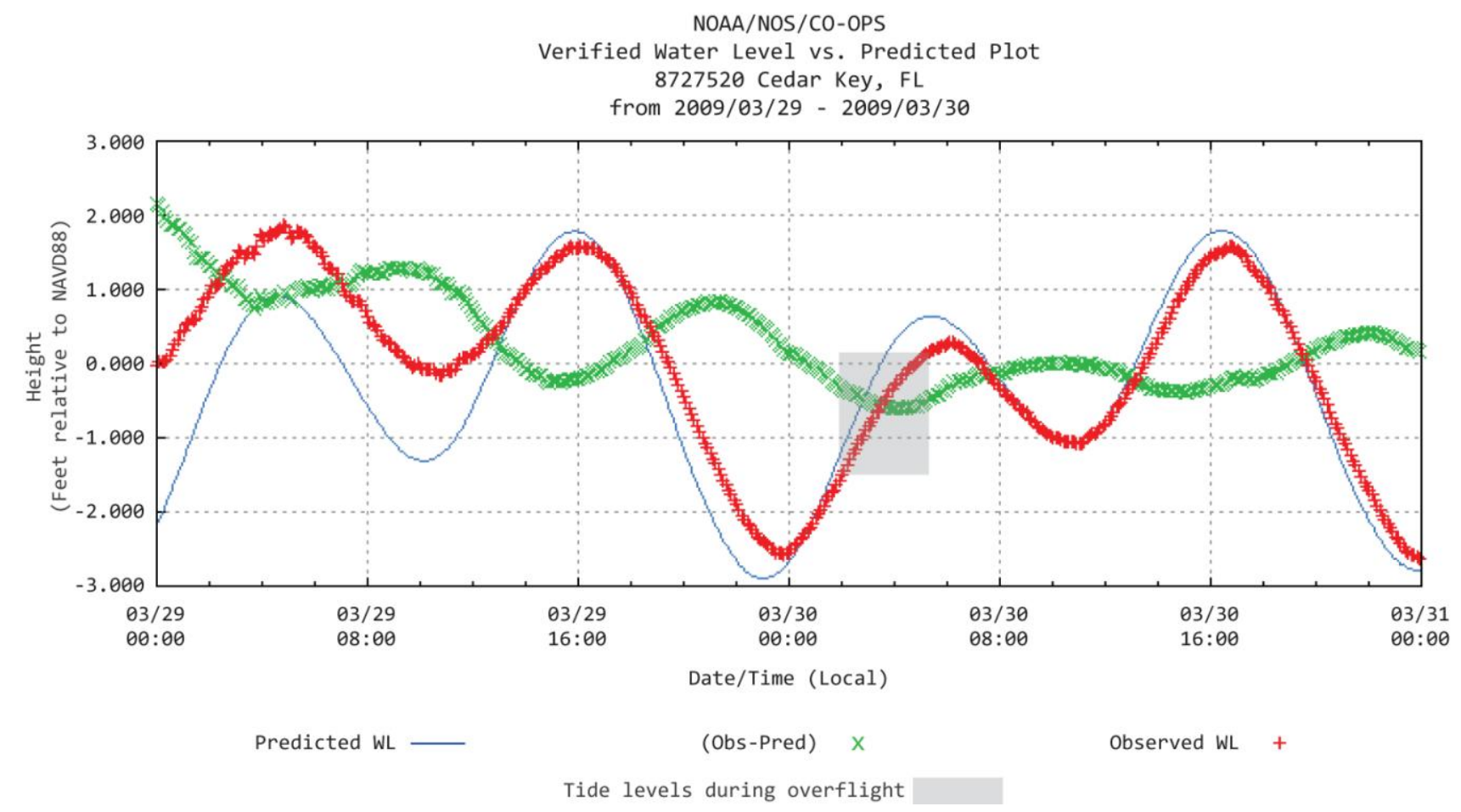

Figure 10. Predicted and observed tide levels (WLs) at Cedar Key for March 29-30, 2009. 


\section{Methods}

Pre-processing of the 2009 TIR imagery included positioning, temperature calibration, and construction of an image mosaic performed by the service provider (VeriMap, 2009b). Data processing, evaluation, and analysis of TIR imagery can include preparing a color-ramp display to visually identify temperature differences (Lillesand and others, 1994; Beck, 2004), or comparing day and night imagery for evaluation of thermal inertia and urban-heat islands (Lo and others, 1997), or using standard statistical and spatial analyses to identify temperature anomalies and their distribution (Davis, 2007). A robust methodology, employing several image-processing steps, was developed for this study by the USGS to evaluate surface-water temperatures across various physical environments and to detect anomalies with a measure of assurance.

Field reconnaissance was conducted in February, March, May, and September 2009. Discharge from Lancaster Spring was measured in February and March. Sites across the region were selected on the basis of accessibility by water, road, and hiking distance, as well as the difference in temperature between anomalies and control sites in nearby ponds and creeks. Water-quality measurements were taken at an accessible edge for each surface-water body. Water temperature, salinity, and $\mathrm{pH}$ were measured using water quality sensors and daily three-point calibration. Site description, photographs, and coordinates were also recorded for each site.

\section{Data Processing}

TIR imagery was processed (using ESRI and ERDAS software) to identify those aquatic features with significantly higher temperature than the surrounding surface water. Original (delivered) radiance values provided detailed temperature differences of about $0.12^{\circ} \mathrm{F}$, and this range of image values (11255) was used in the data analysis to make full use of the precision in the original data. English units are used throughout this report to facilitate ease of use by WBPSP personnel. A $6.5 \times 6.5$-ft pixel can be a single surface feature or a mixture of several landscape components such as marsh canopy, mud bank, and creek. A threshold at image value 50 (approximately $47^{\circ} \mathrm{F}$ ) was established to separate non-aquatic elements from evaluation of water pixels. The lower temperatures included pixels dominated by vegetation, soil, and hard surfaces. Image values above $50\left(48^{\circ} \mathrm{F}\right.$ and above) represented water and mixed-water pixels. Evaluation and analyses were conducted on water pixels only. Final images were prepared in degrees Fahrenheit, and temperature values were reported in degrees Fahrenheit for ease of use and a greater range than Celsius. An overall preliminary view of the imagery converted to degrees Fahrenheit is shown in figure 11. Image artifacts are seen as grid patterns in areas of uniform temperature range (i.e., large bodies of surface water or large tracts of forest). This is a remnant of an image pre-processing step required in the merge and mosaic of flight lines (VeriMap, 2009b). Although the grid pattern itself should be ignored, the underlying patterns of warm temperatures offshore should be examined.

Figure 11 shows the general distribution of large temperature anomalies in the region and represents the color-ramp method of evaluating TIR imagery. Large features may be observed near the mouth of the Waccasassa River, near Corrigan Reef, and in the Gulf of Mexico west of Cedar Key. Cool waters surround the Cedar Keys and emanate from the coast, especially south of Waccasassa River. Many small discharge points are located along the forest/marsh boundary, in solution holes and other karst depressions, and along some tidal creeks. These small features are visible only at larger map scale. Due to the variety of conditions and number of anomalies, a series of steps was employed to identify, map, and evaluate those features of greatest importance to WBPSP. 


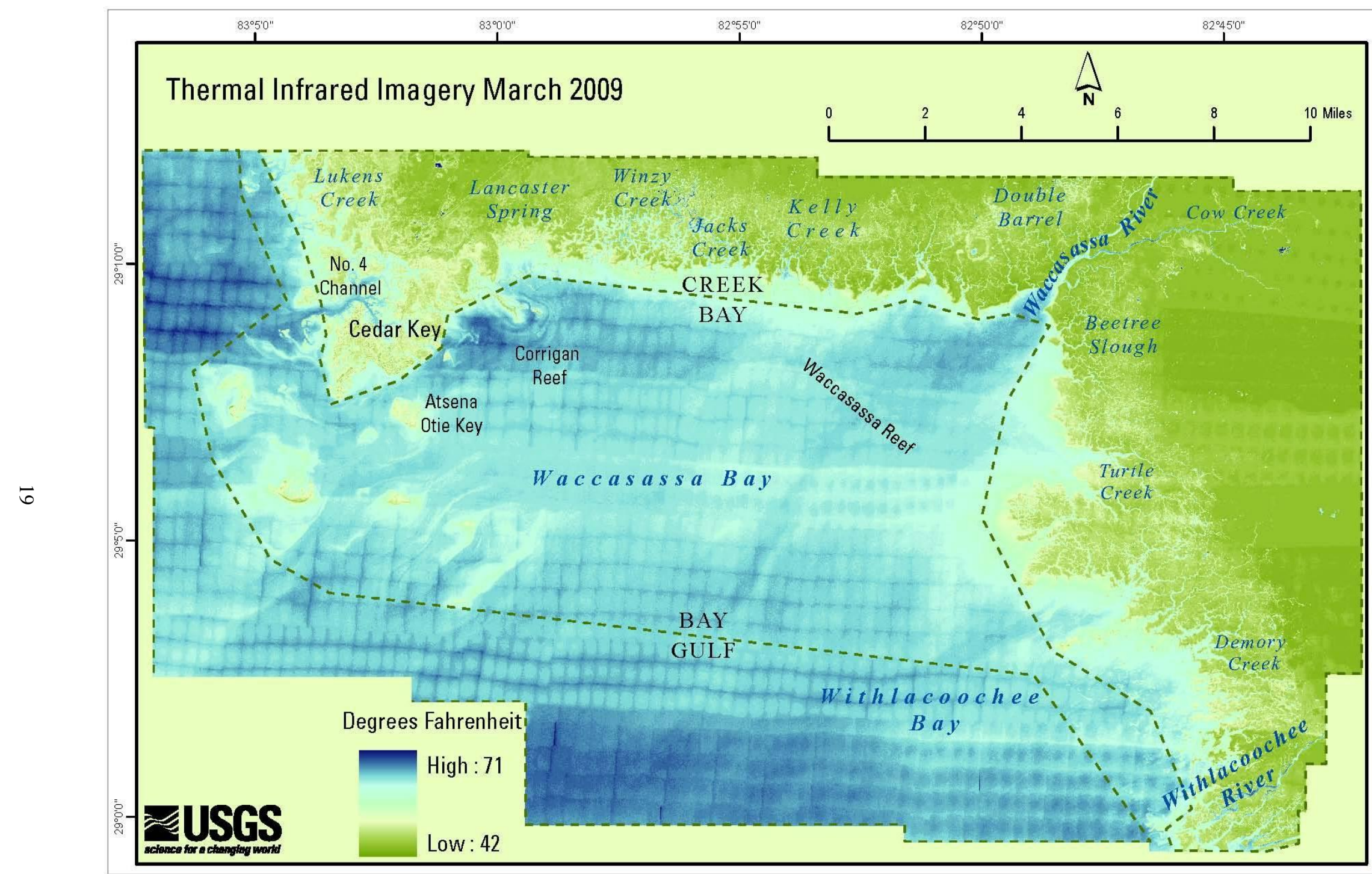

Figure 11. March 2009 TIR imagery, color-mapped for temperature, showing Creek, Bay, and Gulf zones. 


\section{Method Testing}

Several image-processing techniques were attempted in this effort, including simple color mapping and Getis Ord Hot Spot analysis, which identifies concentrations of high temperature values. Although used by others (Davis, 2007), the large image area encompassed by this TIR imagery and the influence from copious "hot spots" proved to grossly limit the application of this method. The Getis Ord analysis delineated areas with large temperature anomalies, all of which were visually obvious (fig. 11), but proved ineffective in distinguishing small or stand-alone features. The Getis Ord analysis resulted in prolific concentration of points in areas such as Corrigan Reef with diminished or no value assigned to small temperature anomalies. To achieve a balanced and robust analysis, an alternative series of image analyses was selected to derive temperature anomalies and their associated traces in a large and varied environment.

\section{Zones}

To manage the range of background temperatures in the varied surface-water bodies, zones were created to confine data processing to separate image sections with similar environmental conditions. The Creek, Bay, and Gulf zones were delineated, generally following the coastline and separating cooler surface-water temperatures in the bay and near shore from warmer temperatures and large artifacts in the Gulf of Mexico (fig. 11). Each zone can be considered a "population" with different attributes, statistics, and thresholds for anomalous characteristics. A similar landscape approach was employed in the processing of laser-altimetry data by dividing the area into units of common character for analysis (Raabe and others, 2008). The three zones for TIR analysis were: (1) Creek (river, tidal creek, and terrestrial aquatic features); (2) Bay (Waccasassa and Withlacoochee Bays and nearshore waters); and (3) Gulf (Gulf of Mexico).

\section{Levels $1-4$}

Summary statistics were calculated for water pixels in each zone. A background temperature range and standard deviation (SD) were established for each zone. Image values near the ambient surface-water temperature range correspond to normal variations due to differences in water depth, substrate, and vegetation cover and do not represent temperature anomalies. An image value with a low probability (occurring in the tail of the distribution) is more likely to represent possible groundwater influence, not random chance or minor variation. These low-probability, high-temperature features were assigned to one of four levels. For each zone, an image value exceeding:

- $1.65 \mathrm{SD}$ is in the 90 percent confidence interval (C.I.) with a probability of 0.1 (Level 1),

- $1.96 \mathrm{SD}$ is in the 95 percent C.I. with a probability of 0.05 (Level 2),

- $2.37 \mathrm{SD}$ is in the 98 percent C.I. with a probability of 0.02 (Level 3),

- $2.58 \mathrm{SD}$ is in the 99 percent C.I. with a probability of 0.01 (Level 4).

Temperature features rated Level 4 represent the highest probability of groundwater discharge. Lower levels represent increased distance from a discharge point or mixing with surface water, and can be considered the trace or plume from groundwater discharge. Level 3 features may also be small or obscured seeps or deeper seeps with a mixed-temperature signal at the surface. Level 2 and Level 1 features in most cases occurred adjacent to Level 3 and Level 4 sites, and represent groundwater discharge mixing with surface water. Levels 1-2 were retained and mapped to help visually identify location, direction of flow, and size or influence of the discharge in the Creek and Bay zones. Numerous Level 1-2 polygons occurred in the grid-like pattern of image artifacts in open Gulf water. Due to the 
large temperature anomalies in the Gulf and numerous image artifacts, only Levels 3 and 4 were retained for the Gulf zone. Area and portion of image covered by each zone and each level were calculated in acres.

\section{Temperature-Anomaly Locations and Trend}

Individual or spot locations are required for some mapping and statistical analyses, and by WBPSP personnel for field reconnaissance, but Level 4 features are polygons, some of them many image pixels across. Each pixel represents a $6.5 \times 6.5-\mathrm{ft}$ surface area. Individual locations for Level 4 temperature anomalies were extracted as the center of each Level 4 polygon from each zone, and recombined as a set of thermal anomaly point locations for the region. Although each polygon "center" may not be the exact location of the actual seep, it is assumed to be sufficiently near to reasonably represent the site and serve to relocate the seep by boat or on foot. Many thermal features in the terrestrial landscape were associated with anthropogenic structures including swimming pools in Cedar Key, excavation sites, road-building borrow pits, and the Florida Barge Canal. Clarity in the thermal imagery and researcher familiarity with the region were employed to identify the shape and configuration of known or obvious anthropogenic sites or image artifacts. Where present, Level 4 points associated with obvious human construction were selected and separated in a GIS. This data set corresponds to thermal anomalies in excavation pits with an associated aquifer discharge, Cedar Key swimming pools, or image mosaic artifacts. The remaining points in the GIS layer are assumed to represent natural seep features unless more local information is obtained.

The variable nature of the subsurface geology highlights the need to understand how surface features, like aquifer-discharge sites, relate to the subsurface geology of the region. Spatial analysis of "directional distribution" was conducted using the naturally occurring thermal point data to determine if the locations were aligned in a particular direction. The analysis produces an ellipse representing the trend, if any. If the points are evenly distributed, the ellipse will be circular; if an underlying geographic trend exists, the ellipse will depict that trend.

\section{Site Density and Dispersal}

A spatial analysis was conducted to identify seeps that are clustered and seeps that are isolated from others. Highly clustered sites indicate increased level of dependence, among identified features, perhaps related to greater permeability or prevailing flow paths. Highly dispersed sites indicate greater independence, perhaps arising from isolated groundwater conduits separated by impermeable layers. Geographic association and heterogeneity can be examined by employing distance and shared attributes such as shared borders or assigned significance level. Cluster and outlier analysis, using both a local and global index (ESRI Anselin's Local Moran tool), was employed to identify areas where temperature anomalies were concentrated and where they occurred in isolation. Using a fixed distance of $0.3 \mathrm{mi}$., the analysis produced Z-scores (standard deviation), p-values (probability), Moran-I-score (degree of concentration or isolation), and a descriptive field. The descriptive field provided a two-letter acronym describing the type of feature: HH (high value surrounded by high values), LL (low surrounded by low values), HL (high value surrounded by low values), and LH (low values surrounded by low values).

The thresholds for feature concentration in the Creek zone were set at Z-score greater than 15, pvalue less than 0.01, Level 4, Moran-I greater than 400, and HH descriptor, producing 100 cluster locations. The volume of clustering produced a prolific number of polygons at significant levels. Threshold for clustering was set high to select those areas with greatest concentration of temperature anomalies. To identify outliers, thresholds were set to Z-score less than -5 , p-value of less than 0.01 , Level 4, and HL descriptor, producing a subset of 32 isolated locations. A similar procedure was 
conducted in the Bay on Level 1-4 polygon features with Z-scores greater than 18 to identify cluster locations and a Z-score less than -2 for outliers. The analysis was not conducted on the Gulf zone due to the large number of artifacts.

\section{Comparison of 2009 and 2005 TIR Imagery}

TIR data collected in March 2009 were compared with an area of overlap with previous TIR imagery collected in March 2005 to aid the interpretation of groundwater discharge sites (VeriMap, 2009b; Raabe and Bialkowska-Jelinska, 2007; fig. 12). The region of overlap covers an area of isolated ponds and creeks east of Cedar Key where flight turns in 2005 captured portions of the landscape covered in 2009. Thirty-nine randomly selected temperature anomalies mapped in 2005 were compared to 2009 imagery. If a site was rated Level 1-4 in 2009, it was considered a positive re-identification in 2009. If a selected site was rated below Level 1 (90 percent C.I.), it was determined to be insignificant in 2009. A positive identification was made if the feature was identified within a 3-pixel radius (20 ft) of the 2005 site to accommodate slight offsets in the imagery and potential differences in flow direction. Although imagery was also examined for the reverse case-temperature anomalies identified in 2009 that were not identified in 2005-occurrences of this type could not be found.

\section{Results}

\section{Zones and Feature Levels}

Temperature range and thresholds were evaluated for each zone (fig. 11). Table 2 shows summary statistics, the ambient temperature range and standard deviation (SD) for Creek, Bay, and Gulf zones. Thresholds for Levels 1, 2, 3, and 4 are given in degrees Fahrenheit.

Table 2. Summary statistics and temperature range in three zones for ambient surface water and Levels 1-4.

[C.I., confidence interval]

\begin{tabular}{|c|c|c|c|}
\hline Value range/zone & Creeks $\left({ }^{\circ} \mathrm{F}\right)$ & Bay $\left({ }^{\circ} \mathrm{F}\right)$ & Gulf $\left({ }^{\circ} \mathrm{F}\right)$ \\
\hline Min/max/mean & $52 / 71 / 59$ & $56 / 70 / 63$ & $58 / 71 / 65$ \\
\hline Standard deviation & 4 & 2 & 2 \\
\hline Number of pixels & $21,292,854$ & $7,310,277$ & $51,171,276$ \\
\hline Ambient temperature range & $52-57$ & $56-61$ & $58-63$ \\
\hline Level 1 (90\% C.I.) & $63.5-64.5$ & $65-65.5$ & $67-67.5$ \\
\hline Level 2 (95\% C.I.) & $64.5-65.5$ & $65.5-66$ & $67.5-68$ \\
\hline Level 3 (98\% C.I.) & $65.6-66.5$ & $66-66.5$ & $68-68.5$ \\
\hline Level 4 (99\% C.I.) & $66.5-71$ & $66.5-69$ & $68.5-71$ \\
\hline
\end{tabular}

Level 4 represents the best prospect of a discharge feature, and lower levels represent progressively lower importance or increased likelihood of mixing and distance from a seep. The temperature difference between the maximum ambient surface-water temperatures and the Level 4 features was greater than $9.5^{\circ} \mathrm{F}$ in the Creek zone, and $5.5^{\circ} \mathrm{F}$ in the Bay and Gulf zones. A greater range of temperature in the Creek zone, as evidenced by the higher standard deviation, is due to varying topography and vegetation and the contribution of sediments and hard surfaces (to mixed pixels) that cool at a faster rate than water. 


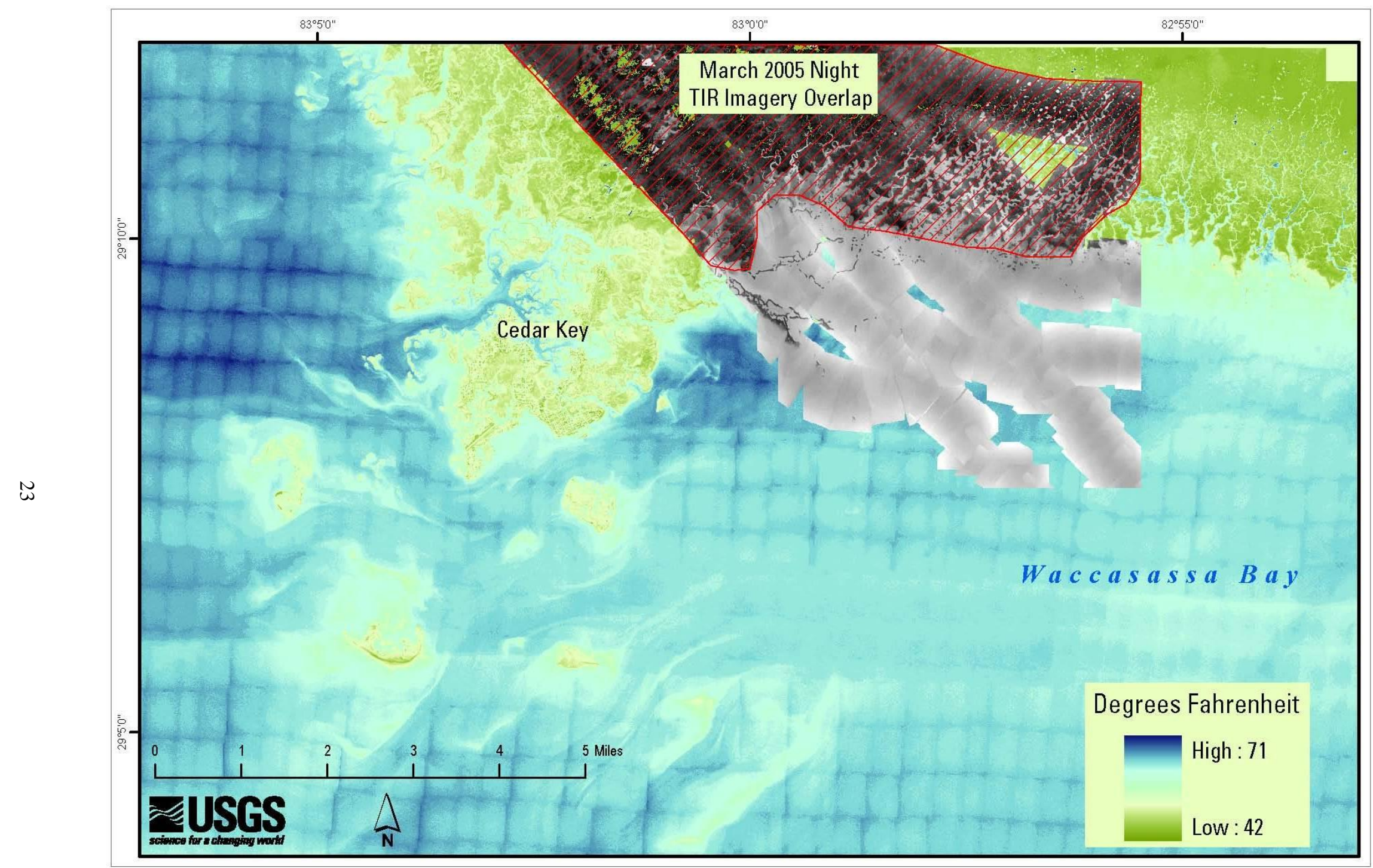

Figure 12. Image overlap and area of comparison between March 2005 and March 2009 night TIR. 
Table 3 provides a conversion from degrees Fahrenheit to degrees Celsius and shows the ambient water temperature and temperature-anomaly range for each zone in shades of gray. The area between the land/water threshold and ambient surface-water temperature represents a buffer range for mixed pixels that may include contributions from water, land, and vegetation. Table 3 highlights the large differences between Creek and Gulf temperatures. Temperatures in the Bay are similar to the temperature range in the Creeks, but have a substantially smaller standard deviation and do not exceed $69^{\circ} \mathrm{F}$. The gray cells demarcate ambient and Level 4 surface-water temperatures, illustrating the differences between each zone and the rationale for conducting separate statistical analyses by zone. There is virtually no overlap in ambient surface-water temperature of the Creek and Gulf zones, and respective thresholds for each Level differ by at least $3{ }^{\circ} \mathrm{F}$ between zones (table 3 ).

Figure 13 shows regional anomalies using color enhancement of Levels 1-4. This is similar to a color ramp that represents relative temperatures, but Levels 1-4 represent statistically significant temperatures for each zone. Temperature anomalies were visible at full image scale along Winzy Creek and Cow Creek, Corrigan Reef, Number 4 Channel, Withlacoochee River, and a submarine feature extending from the mouth of the Waccasassa River toward the middle of Waccasassa Bay.

Table 3. Temperature conversion, image values, ambient surface-water temperature, and feature range.

\begin{tabular}{|c|c|c|c|c|c|}
\hline \multicolumn{2}{|c|}{ Temperature } & \multirow{2}{*}{$\begin{array}{l}\text { Image } \\
\text { value }\end{array}$} & \multirow{2}{*}{$\begin{array}{l}\text { Creek ambient } \\
\text { water and feature } \\
\text { range }\end{array}$} & \multirow{2}{*}{$\begin{array}{l}\text { Bay ambient } \\
\text { water and } \\
\text { feature range }\end{array}$} & \multirow{2}{*}{$\begin{array}{c}\text { Gulf ambient } \\
\text { water and } \\
\text { feature range }\end{array}$} \\
\hline $\begin{array}{c}\text { Degrees } \\
\text { Fahrenheit }\end{array}$ & Degrees Celsius & & & & \\
\hline 71 & 21.6 & $248-255$ & & & \\
\hline 70 & 21.1 & $239-247$ & & & \\
\hline 69 & 20.5 & $231-238$ & & & 4 \\
\hline 68 & 20 & $223-230$ & & & 3 \\
\hline 67 & 19.4 & $214-222$ & & 4 & \\
\hline 66 & 18.8 & $206-213$ & 4 & 3 & \\
\hline 65 & 18.3 & $198-205$ & 3 & $1 \& 2$ & \\
\hline 64 & 17.7 & 189-197 & 2 & & \\
\hline 63 & 17.2 & 181-188 & 1 & & \\
\hline 62 & 16.6 & 173-180 & & & \\
\hline 61 & 16.1 & 164-172 & & \multirow{6}{*}{$\begin{array}{l}\text { Ambient } \\
\text { water } \\
\text { temperature }\end{array}$} & Ambient \\
\hline 60 & 15.5 & $156-163$ & & & $\begin{array}{l}\text { water } \\
\text { temnerature }\end{array}$ \\
\hline 59 & 15 & $147-155$ & & & \\
\hline 58 & 14.4 & $139-147$ & & & \\
\hline 57 & 13.8 & $131-138$ & \multirow{6}{*}{$\begin{array}{l}\text { Ambient } \\
\text { water } \\
\text { temperature }\end{array}$} & & \\
\hline 56 & 13.3 & $123-130$ & & & \\
\hline 55 & 12.7 & $114-122$ & & & \\
\hline 54 & 12.2 & $106-113$ & & & \\
\hline 53 & 11.6 & $98-105$ & & & \\
\hline 52 & 11.1 & $89-97$ & & & \\
\hline 51 & 10.5 & $81-88$ & & & \\
\hline 50 & 10 & $73-80$ & & & \\
\hline 49 & 9.4 & $64-72$ & & & \\
\hline 48 & 8.8 & $56-63$ & & & \\
\hline 47 & 8.3 & $48-55$ & \multicolumn{3}{|c|}{ Surface-water threshold } \\
\hline 46 & 7.7 & $39-47$ & & & \\
\hline 45 & 7.2 & $31-38$ & & & \\
\hline 44 & 6.6 & $23-30$ & & & \\
\hline 43 & 6.1 & $14-22$ & & & \\
\hline 42 & 5.5 & $11-13$ & & & \\
\hline
\end{tabular}




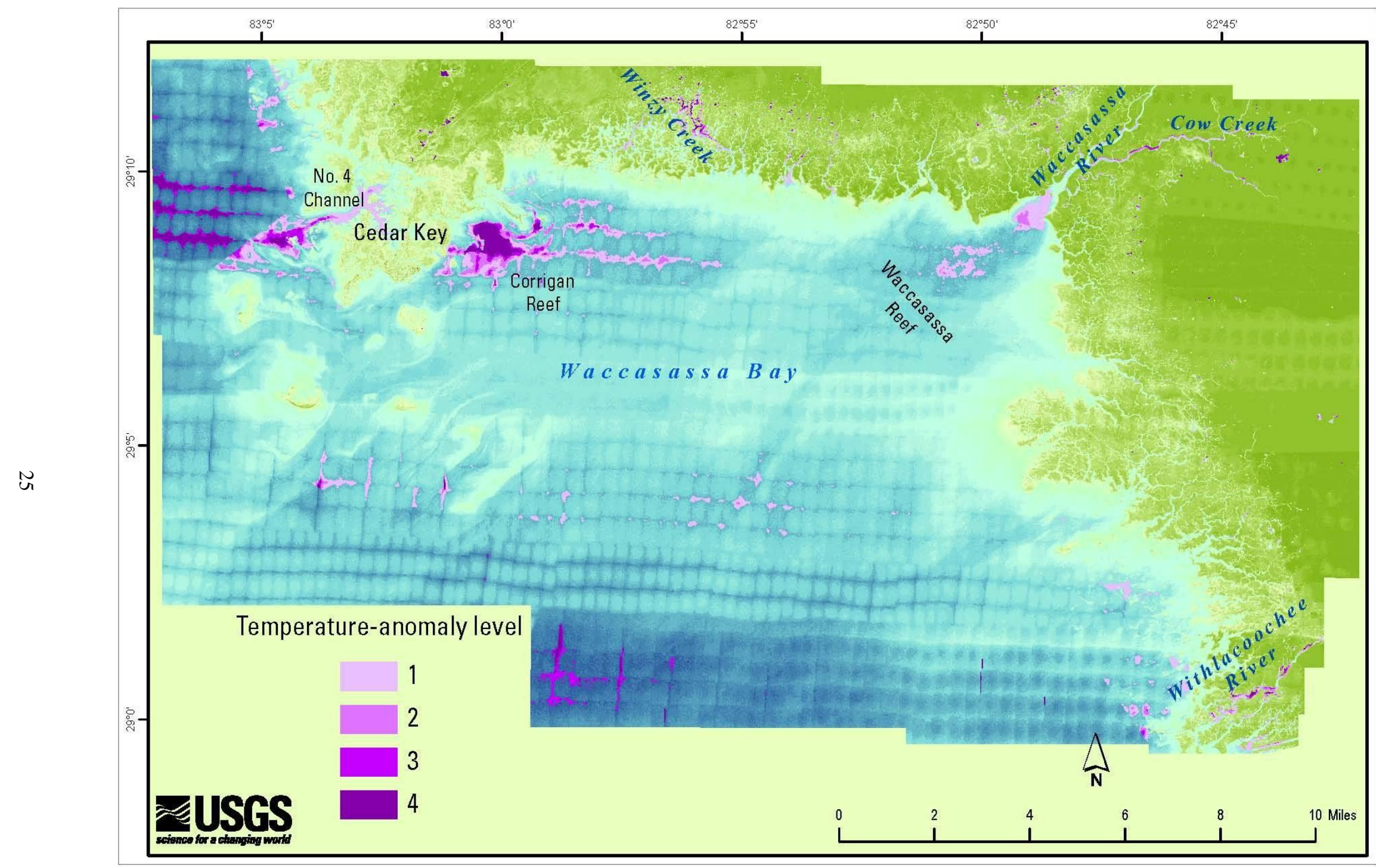

Figure 13. Waccasassa Bay region temperature-anomaly Levels 1-4 showing submarine seep sites. 
The variance in levels (image pixel color) can be attributed to size of feature, the amount of mixing between surface waters and seep, and depth or distance from the feature. Figures 14 and 15 provide a detailed look at two areas, Winzy Creek and Waccasassa River, respectively, using colorcoded Levels 1-4. Features in Winzy Creek display parallel and jointed fracture patterns and a line of depression features with a thermal signal, approximately 1.5 to $2 \mathrm{mi}$ from the coast (fig. 14). Features near the Waccasassa River were concentrated along Cow Creek, emanating from Lone Cedar Island in the river mouth, and show a similar distribution of thermally significant depression features 1.5 to $2 \mathrm{mi}$ from the coast (fig. 15).

The acreage of each significant temperature Level in each zone was determined (table 4). Levels 1-4 combined represent about 1.5 percent of the total image area. Level 4 polygons, the seep locations, represent 0.2 percent of the total image area.

Table 4. Acreage of Creek, Bay, and Gulf zones and significant temperature, Levels 1-4, in each zone.

\begin{tabular}{|c|r|r|r|r|}
\hline \multirow{2}{*}{ Level } & \multicolumn{4}{|c|}{ Acreage } \\
\cline { 2 - 5 } & \multicolumn{1}{|c|}{ Creek } & \multicolumn{1}{|c|}{ Bay } & \multicolumn{1}{c|}{ Gulf } & \multicolumn{1}{c|}{ Total } \\
\hline $\mathbf{1}$ & 370 & 1042 & NA & 1,412 \\
\hline $\mathbf{2}$ & 145 & 442 & NA & 587 \\
\hline $\mathbf{3}$ & 45 & 270 & 286 & 601 \\
\hline $\mathbf{4}$ & 49 & 196 & 164 & 409 \\
\hline Levels 1-4 & 609 & 1,950 & 450 & 3,009 \\
\hline Total area & 21,045 & 146,050 & 50,577 & 217,672 \\
\hline
\end{tabular}

\section{Temperature-Anomaly Location and Directional Trend}

Individual locations for Level 4 temperature anomalies were plotted at the center of each Level 4 polygon from each zone, and recombined for a total of 488 locations throughout the region. Eighty points were positively identified as artifacts of anthropogenic origin. The remaining 408 points represent natural seep features. Figure 16 depicts the locations of 488 identified temperature anomalies, colorcoded as natural or artificial features.

A geographic analysis determined the directional distribution of 408 identified natural seeps. The analysis produced an ellipse with a northwest and southeast trend. Figure 17 shows the natural seep-feature ellipse superimposed over the northwest fault strikes (Prowell, 1983) and joint and fracture patterns (Vernon, 1951). The distribution of seep locations produced a broad ellipse trending in the same direction as the fault lines.

\section{Site Density and Dispersal}

Cluster and outlier analyses were used to identify highly clustered temperature anomalies and yielded 100 cluster locations in Creek and Bay zones. A set of 45 isolated locations was identified in the Creek and Bay zones. High feature density was mapped at Winzy Creek and Cow Creek, and at excavation sites near Cedar Key and in the eastern region between Cow Creek and Yankeetown. Outliers, or isolated features, occurred at greatest distances from other "hot spots," and had the lowest Z-scores. These features are located throughout the region, near the Waccasassa and Withlacoochee Rivers, near Cedar Key and in the eastern section of WBPSP. Figure 18 shows the distribution of Creek and Bay sites with color-coded symbols highlighting concentrations of temperature anomalies and the location of isolated, or dispersed, features. 


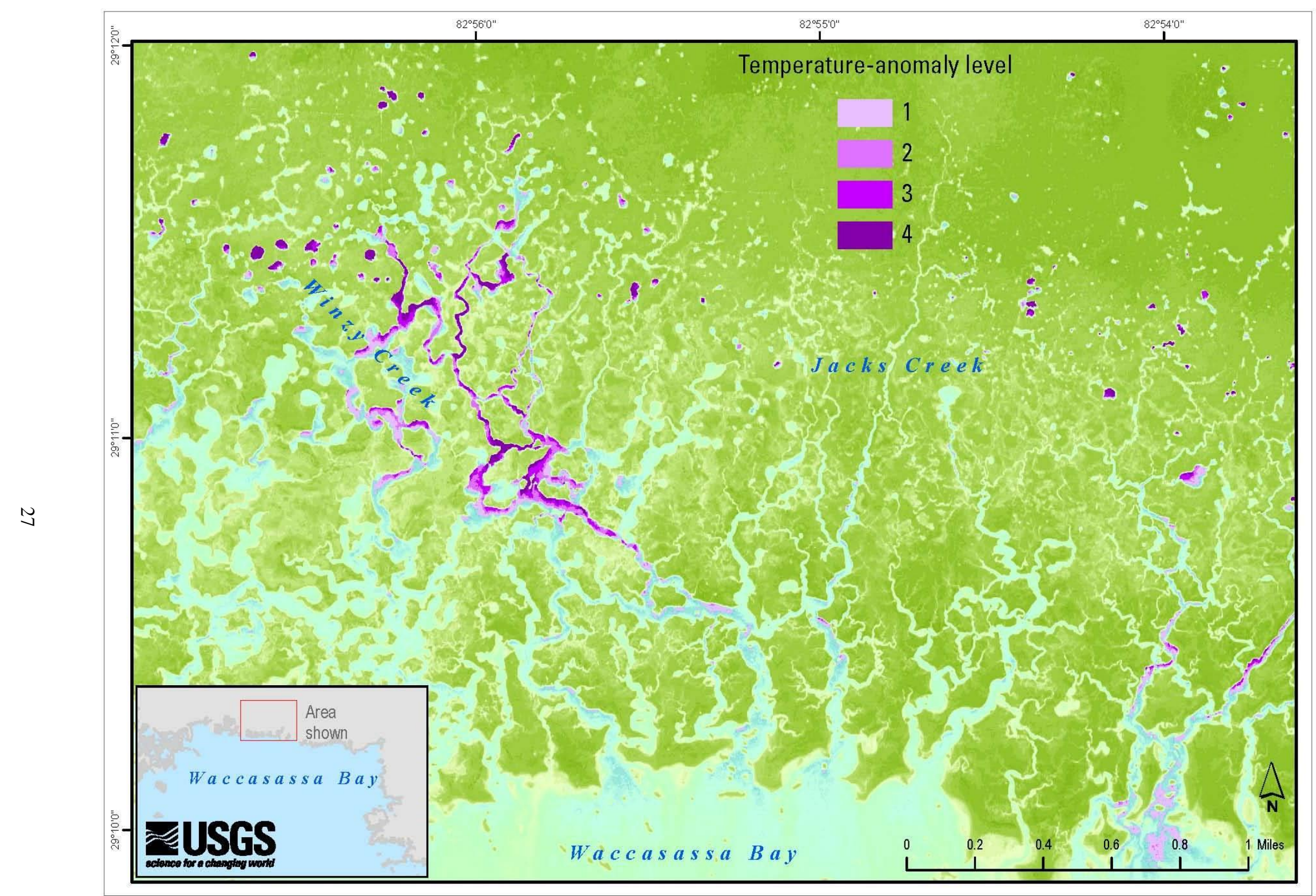

Figure 14. Winzy Creek TIR imagery showing Levels 1-4 along tidal creek. 


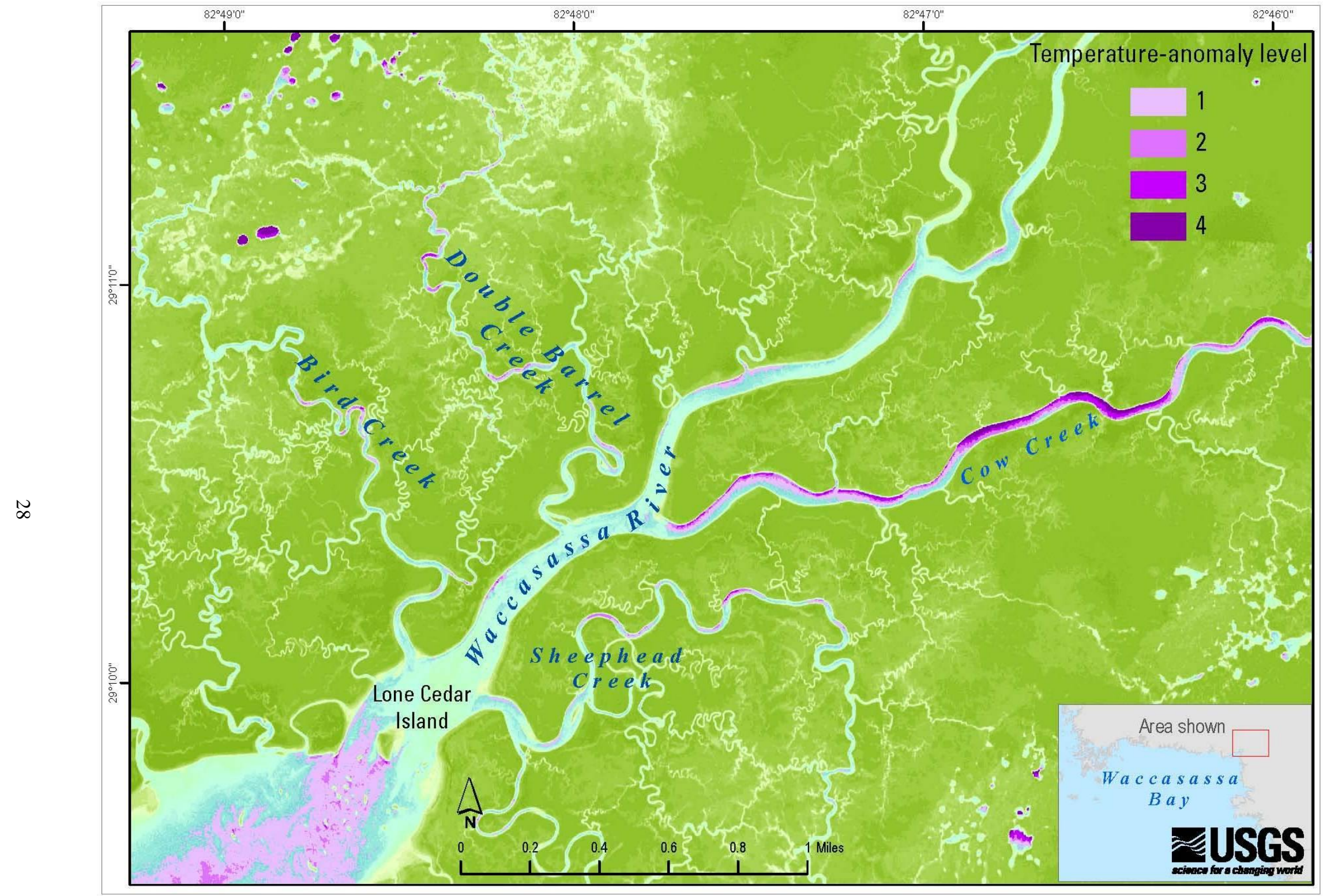

Figure 15. Waccasassa River TIR imagery showing Levels 1-4. 


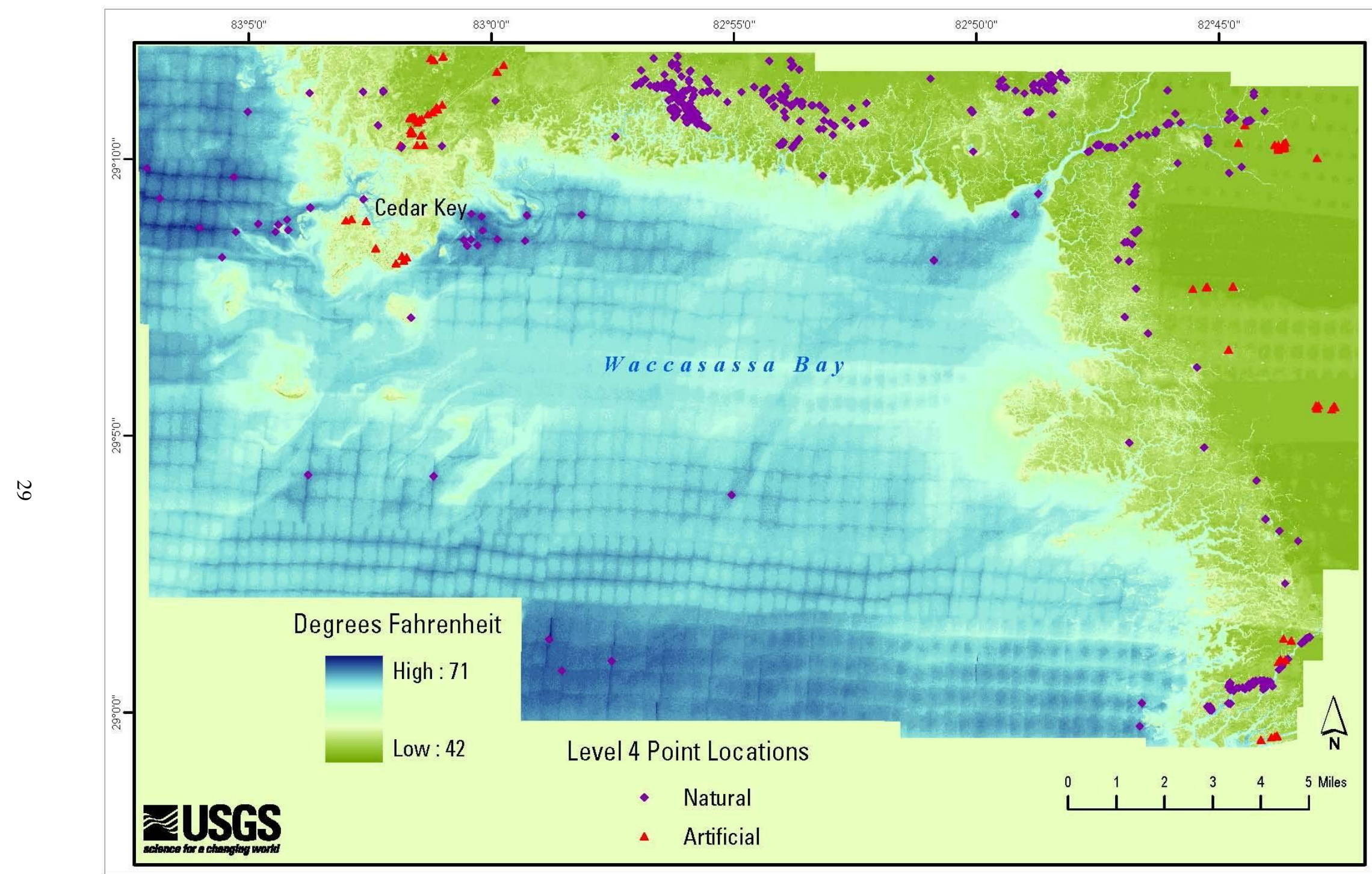

Figure 16. Level 4 temperature-anomaly point locations color-coded as natural or artificial features. 


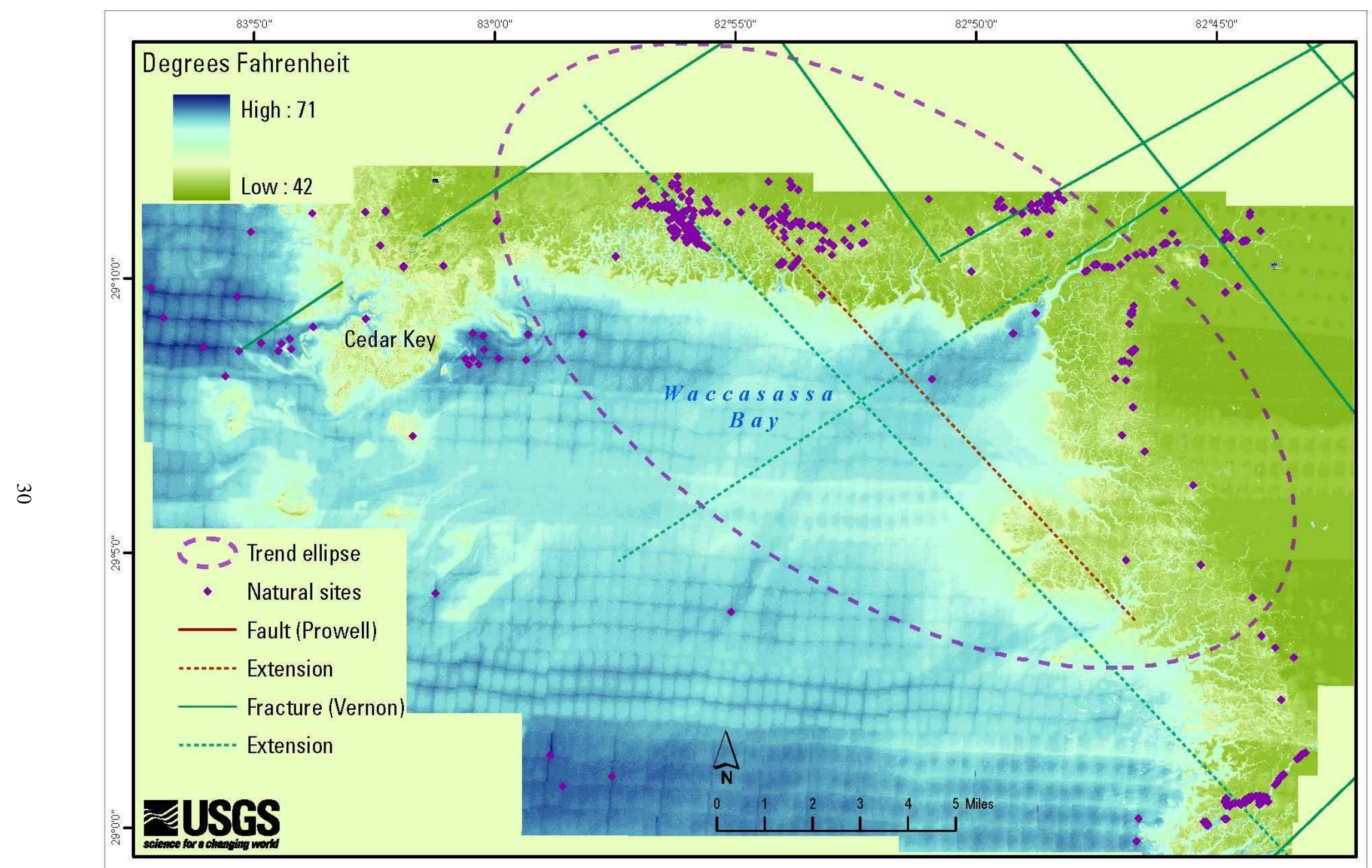

Figure 17. Trend ellipse of natural temperature anomalies aligned in a northwest direction with fault strikes. 


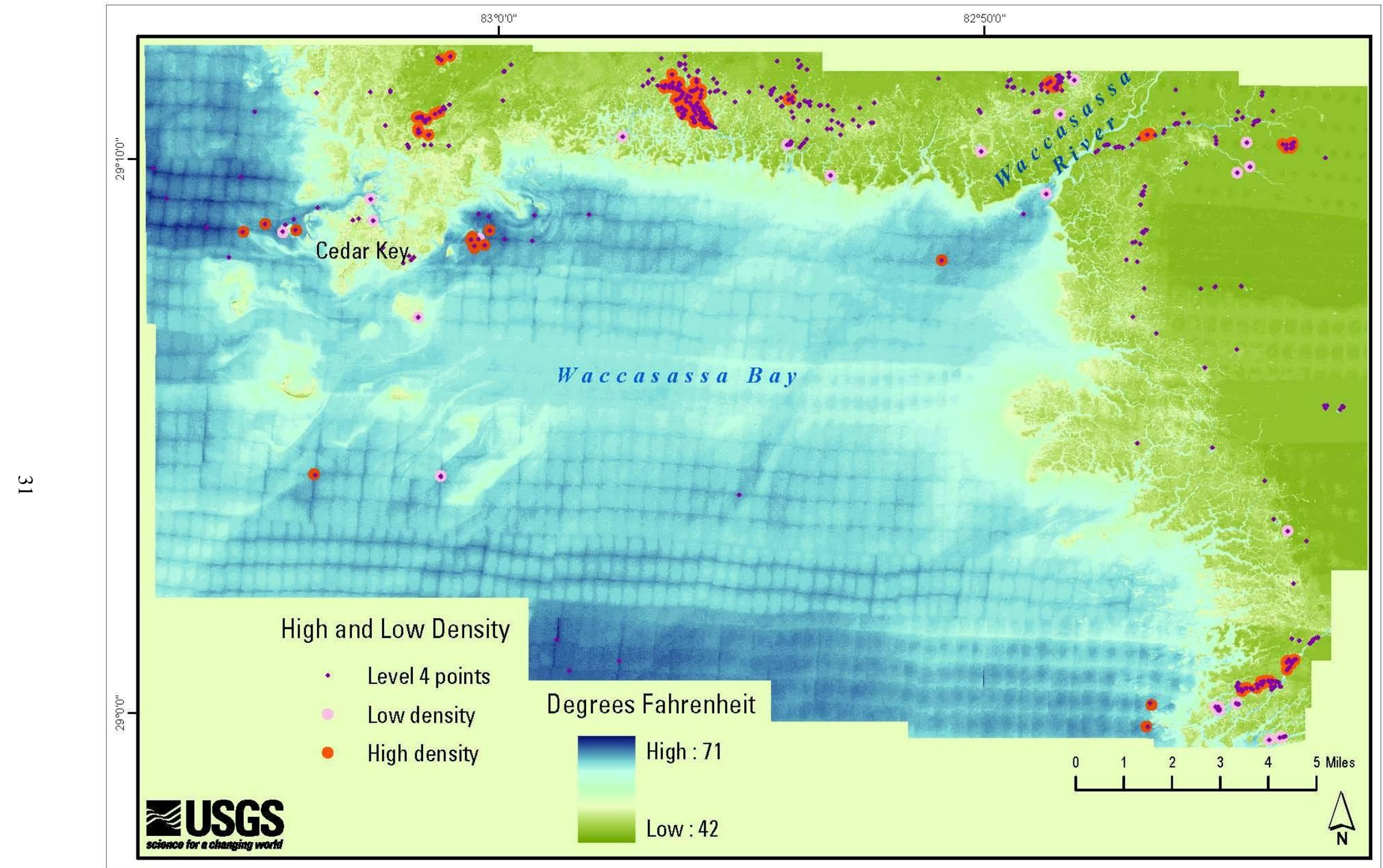

Figure 18. Density of Level 4 temperature anomalies showing clustering and isolation of features. 


\section{Comparison with March 2005 Imagery}

Temperature anomalies identified in March 2005 TIR imagery (Raabe and Bialkowska-Jelinska, 2007) were compared to those identified in March 2009 imagery. Twenty-six of 39 sites were positively re-identified in 2009, and of these, 14 sites were significant at Level 4 (99 percent C.I). One-third of the sites identified in 2005 imagery could not be positively identified by temperature contrast in 2009 imagery. These sites had temperature values below Level 1 (90 percent C.I.) and were determined to be insignificant in 2009. However, all features significant at Levels 1-4 in 2009 (within image overlap; fig. 12) had been positively identified as temperature anomalies in 2005.

An example of the comparison between 2005 and 2009 TIR imagery can be seen at Lancaster Spring, a well-established coastal spring (Scott and others, 2004; figs. 19 and 20). The spring itself is located approximately $1 \mathrm{mi}$ from the coast. Spring Creek, the spring-fed tidal creek, meanders southward to Waccasassa Bay east of Cedar Key. Lancaster Spring consists of a 6.5 -ft deep pool with several boils surrounded by a narrow coastal hammock bordered on the west by sawgrass, to the south and east by salt marsh, and to the north by an elevated dirt road. Lancaster Spring and Spring Creek were among those sites with reduced thermal signature in the 2009 imagery (fig. 20a). Although this site was identified in both 2005 and 2009, the spring was rated Level 3 in 2009, and no thermal trace was indicated in the tidal creek. In 2005, Lancaster Spring showed a large thermal anomaly at the spring and thermal traces within the tidal creek (fig. 20b).

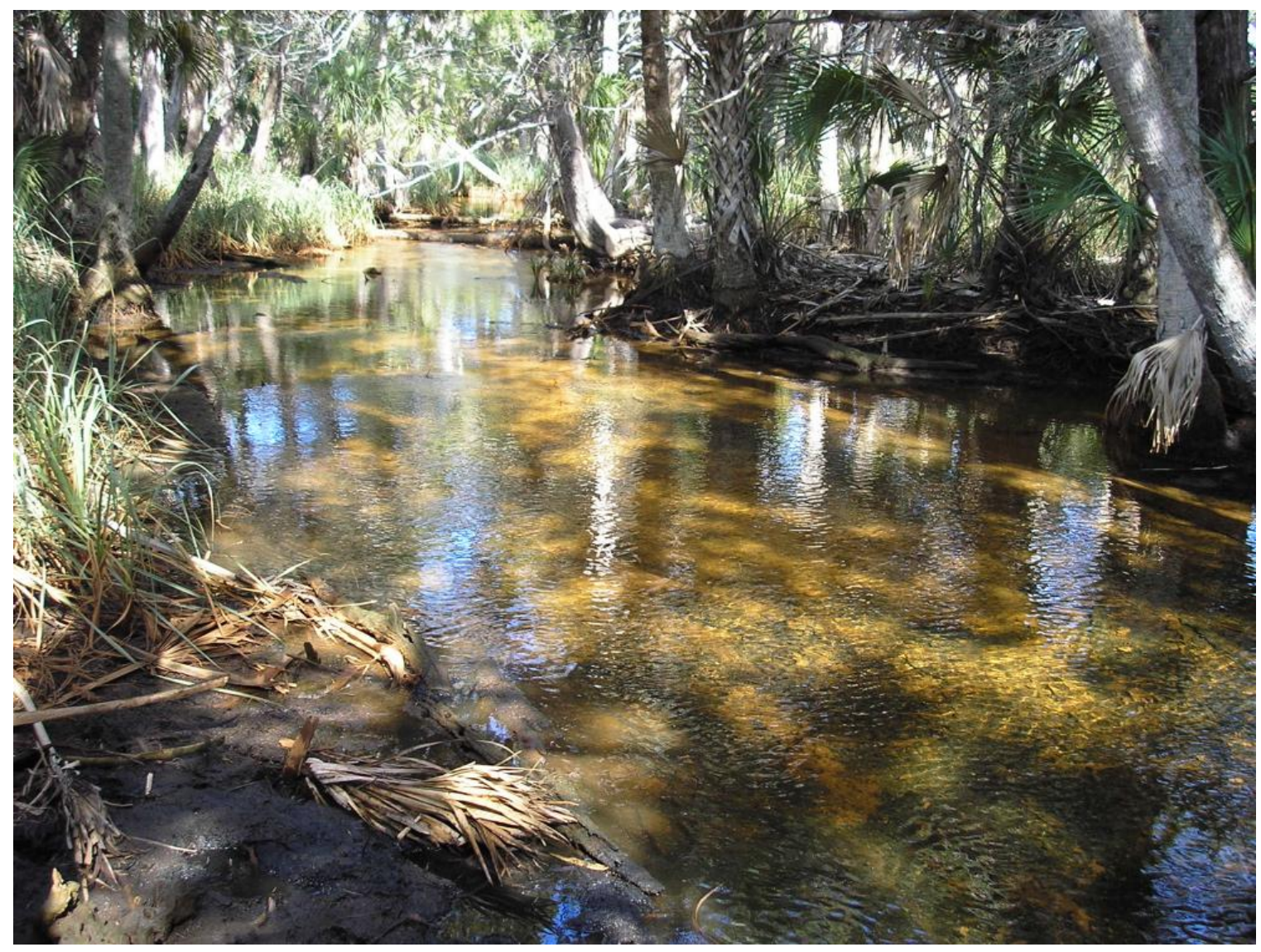

Figure 19. Lancaster Spring looking north along the spring run, February 2009. 


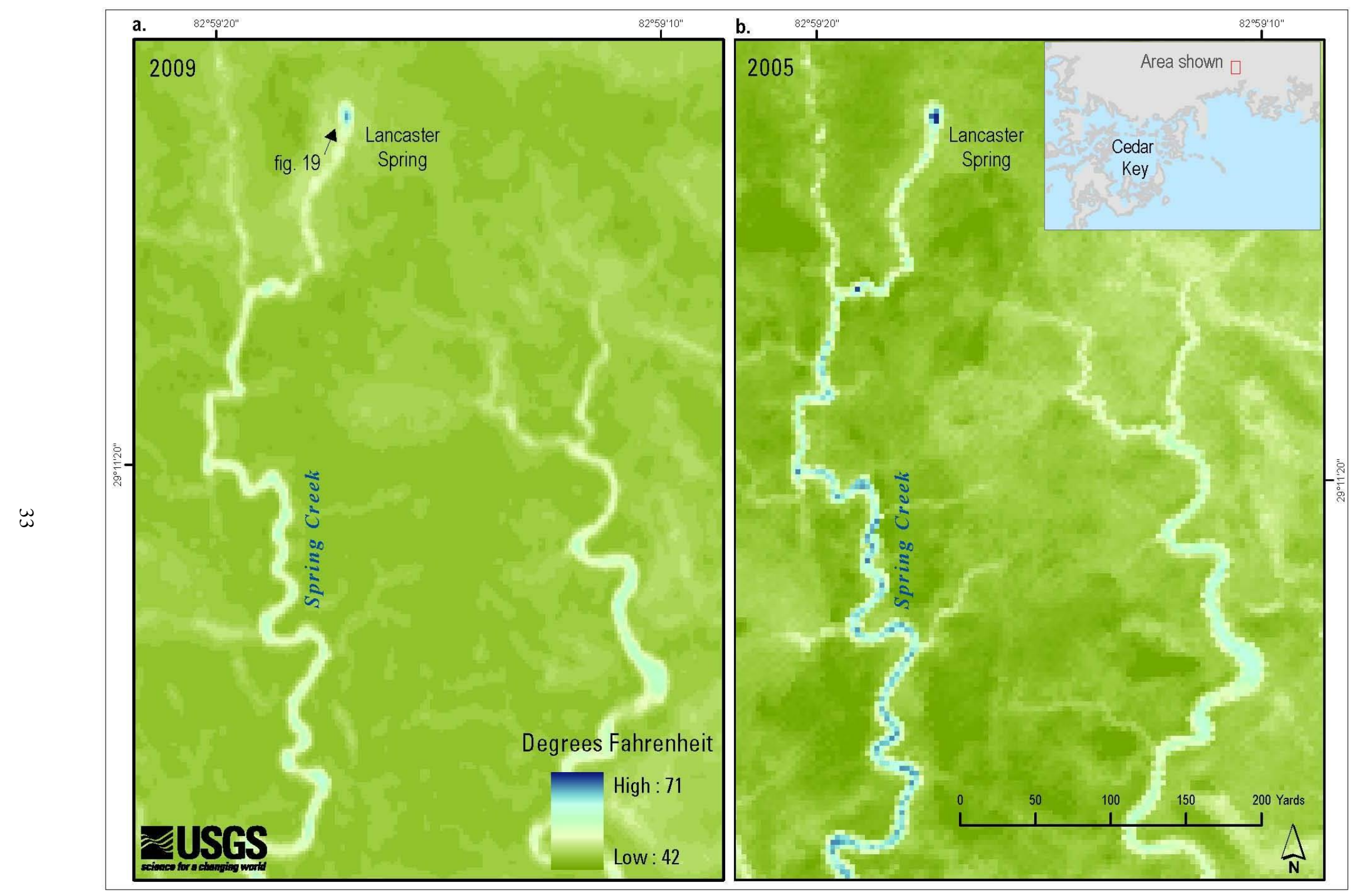

Figure 20. Thermal signature at Lancaster Spring was low in $2009 \mathrm{TIR}$ (a) compared to $2005 \mathrm{TIR}$ (b). 


\section{Field Reconnaissance}

Field reconnaissance (fig. 21) was conducted prior to and following image acquisition in 2009. Discharge measurements were taken at Lancaster Spring, a known and accessible site near the WBPSP office. Discharge at this site was visually estimated at $5 \mathrm{ft}^{3} / \mathrm{s}$ by Florida Geological Survey (FGS) in 1999 (Scott and others, 2004). The discharge at this site was 3.5 and $2.8 \mathrm{ft}^{3} / \mathrm{s}$ in February and March 2009, respectively (USGS, 2009). Salinity at Lancaster Spring was 2 and 10 parts per thousand (ppt), respectively. Although both measurements were taken at low tide, variability at this site was due in part to declining groundwater levels between measurements and in part to the large tide cycle. February reconnaissance also included sites in the Kelly Creek and Ballpark area where salinities were brackish, and a few of these sites exhibited thermal signatures. Access to sites reached by boat or on foot was difficult. Field conditions, site inaccessibility, deep water, mud, and wildlife all hampered the identification and sampling of vents, or access to seeps located in ponds during all seasons.

Measurements were taken at an accessible edge of a water feature. Both identified thermal anomalies and control sites were visited in May at the end of the dry season. May water temperatures ranged from 64-91 ${ }^{\circ} \mathrm{F}$, overlapping aquifer temperature range and compromising the ability to make field identifications with a temperature signal. Salinities ranged from 0.1 to 31 parts per thousand (ppt), and $\mathrm{pH}$ ranged from 5.9 to 8.9. A strong marine influence, in the form of estuarine salinities, was noted 1.5 mi inland and freshwater influence as close as $0.2 \mathrm{mi}$ from the coast. Lowest salinities occurred at borrow pits or at sites greater than $2 \mathrm{mi}$ inland. The estuarine salinity breakpoint appeared to be located between 1.5 and $1.7 \mathrm{mi}$ inland from the coast. Exceptions were noted northeast of Cedar Key and at a deep, but small dissolution feature in the Beckwell area.

The September field survey revealed a similar pattern despite the "wet" season designation. Surface-water temperatures were expected to be higher than the FAS temperature, and ranged from 75 to $102{ }^{\circ} \mathrm{F}$. Salinity ranged from 0.4 to $26 \mathrm{ppt}$, and $\mathrm{pH}$ ranged from 7.0 to 8.9. Many ponds were less saline than in May, but estuarine salinities were noted up to $1.9 \mathrm{mi}$ inland (in the Squarewell area). In some locations, the freshest, most thermally unique of a series of ponds was the one closest to the coast (as in Beetree Slough area). Unique signal (low summer temperature and low salinity) was identified at depth at a small karst dissolution feature in Winzy Creek, where water depth exceeded the 25-ft sensor cable length. Field surveys show strong saltwater influence up to $2 \mathrm{mi}$ from the coast, with implications of a low water table and possible seawater intrusion. Historically, the SRWMD documented up to $5 \mathrm{ft}$ of fluctuation in the potentiometric surface in the region.

Physical characteristics, such as sediment deposits and exposed limestone, were present throughout the region. Surface-water clarity and color ranged from clear tannin, to murky rust, to muddy. Although no single characteristic was reliably associated with identified thermal anomalies, identified sites may exhibit biota and/or biogeochemical processes. This is a degraded landscape, revealing the combined influence of storm surge and sea-level rise, road building, and other effects. Old roadbeds, berms and fence lines, buggy trails, and the effects of historic and modern logging are pervasive. Wildlife activity, feral hogs, alligators, and wading-bird rookeries were notable. Sea-level rise and storm surge have left an indelible mark - affected areas (circa 1993) have been converted to tidal marsh instead of recovering as coastal forest. Salt marsh meadows and tidal creeks have surrounded and overtaken downed trees and salt-stressed coastal hammocks. 


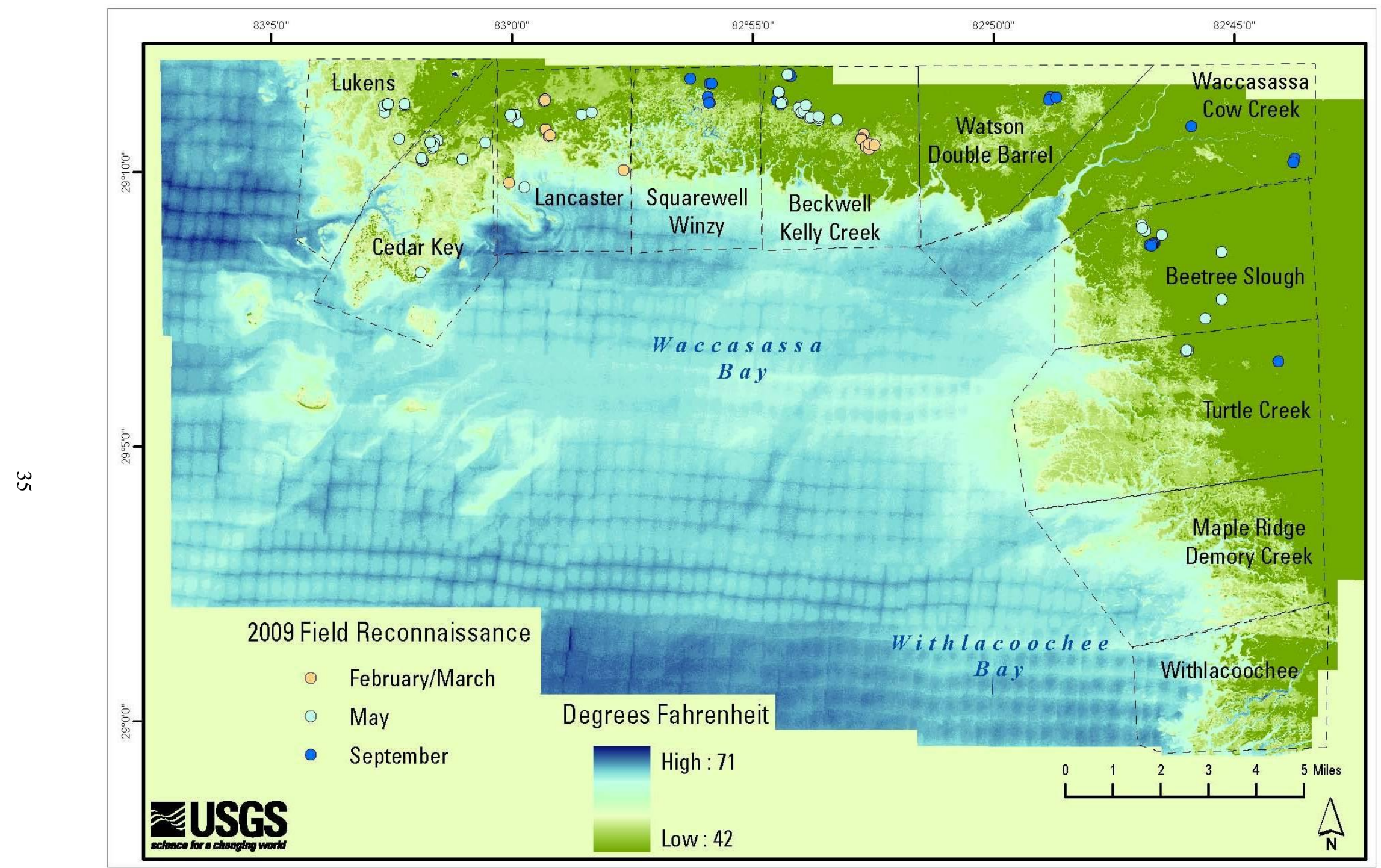

Figure 21. Field reconnaissance locations and area names. 


\section{Discussion}

The large geographic area of the 2009 TIR over Levy County presented a wide range of ambient temperatures in regional surface-water bodies. Gulf waters were considerably warmer than terrestrial creeks and ponds. The large size of a submarine feature near Corrigan Reef and high density of image artifacts in open water dwarfed smaller, isolated terrestrial features. Derivation of temperature anomalies was accomplished by (1) dividing the image into zones of similar environmental content, (2) determining the ambient surface-water temperature in each zone, and (3) extracting temperature anomalies from Level 1 to Level 4 in each zone, where Level 4 represented the greatest likelihood of groundwater discharge to the surface. The division into zones preserved the lower background surfacewater temperature within the terrestrial landscape. Several topics call for expanded discussion: feature omission, a revisit of the diurnal cycle, TIR imagery as compared to field reconnaissance, and the influence of underlying geology on groundwater-flow paths.

\section{Feature Omission}

Three factors contributed to the risk of feature omission: a low water table, warming temperatures, and image artifacts. Regional climate conditions were notably different during and prior to image acquisition in March 2005 and March 2009, as presented in the Regional Hydrologic Conditions section (figs. 6-9). The sites unidentified in 2009 in the image overlap represent a 33-percent risk of feature omission in the 2009 imagery. Diminished discharge may render a site indistinguishable from temperature variations in the surrounding landscape during a drought, but the same site may flow and be identified by temperature contrast in TIR imagery during wet years. Comparison of two TIR images indicated that replication is feasible, but errors of omission may occur, especially between periods with different groundwater and flow conditions. It is unlikely that reverse flow was observed in the TIR imagery, considering the low-tide level during image acquisition (fig. 10).

Air temperature dropped $20^{\circ} \mathrm{F}$ or more below the normal temperature $\left(71-72{ }^{\circ} \mathrm{F}\right)$ of the FAS, and ambient surface-water temperature in the Gulf of Mexico dipped several degrees below typical FAS temperature during the time of data acquisition (tables 1 and 3). The coincidences of a cold snap with image acquisition reduced background temperatures to a sufficient degree so that some discharge features were distinguishable in open water. Identified open-water sites include large features at Corrigan Reef and Number 4 Channel, a single feature on Atsena Otie Key, and a southwest-trending line of features extending from the mouth of Waccasassa River, across the Waccasassa Reefs, and into Waccasassa Bay. Discharge features entering directly into the Gulf or Bay may not be detected if the discharge source is deep or small, or if the ambient surface-water temperature does not provide sufficient contrast. Image artifacts in open water further contributed to the poor detection of submarine vents. The combination of image artifacts, drought conditions, and warming Gulf waters indicate that submarine vents may be larger and/or more numerous than depicted by the 2009 TIR imagery.

\section{Diurnal Cycle Revisited}

Apparent confusion exists over the origin of temperature anomalies in nighttime TIR imagery. It has been inferred that thermal anomalies detected in nighttime TIR imagery may be related to the retention and release of solar energy from sediments (Kincaid, 2009). This may be a misunderstanding of the properties of water compared to sediments and the process of diurnal heating and cooling. The solar gain of wet substrate is small compared to water and other surfaces, and most stored infrared radiation is released shortly after sunset (fig. 5). As the cooling process continues through the night, cold air drainage produces a concentration of cold temperatures in low areas such as valleys and 
depression features. A combination of temperature contrast, pattern recognition, and an understanding of thermal inertia may aid the interpretation of TIR images. Maps and photos at Lukens Creek and Cedar Key provide guidance on viewing and understanding infrared radiance from different surface materials.

\section{Lukens Creek}

A double pond with a strong thermal signal rated Level 4 is situated between two hammocks surrounded by tidal marsh near the head of Lukens Creek (fig. 22). Figure 23 shows the upper portion of Lukens Creek with a color-infrared (CIR) image on the left (fig. 23a) and TIR night image on the right (fig. 23b). Natural features in this area of the Cedar Key Scrub Reserve include coastal hammock, oak scrub, marsh, creek, sand bars, and varying degrees of exposed, wetted, and vegetated soils. Most of the natural surface features range from 44 to $55^{\circ} \mathrm{F}$. Notable features include the sand bars to the west, the partially vegetated wet marsh, and areas with tree canopy. No natural material in this image compares thermally with Lukens Creek or the temperature anomaly in the ponds despite the presence of a sand hill, sand bars, and surface-water flow paths traversing the area. Field observations of high marsh grasses, sawgrass meadows to the north and east, and a decaying alligator nest situated along the "warmest" pond edge, indicate freshwater flow may be present here.

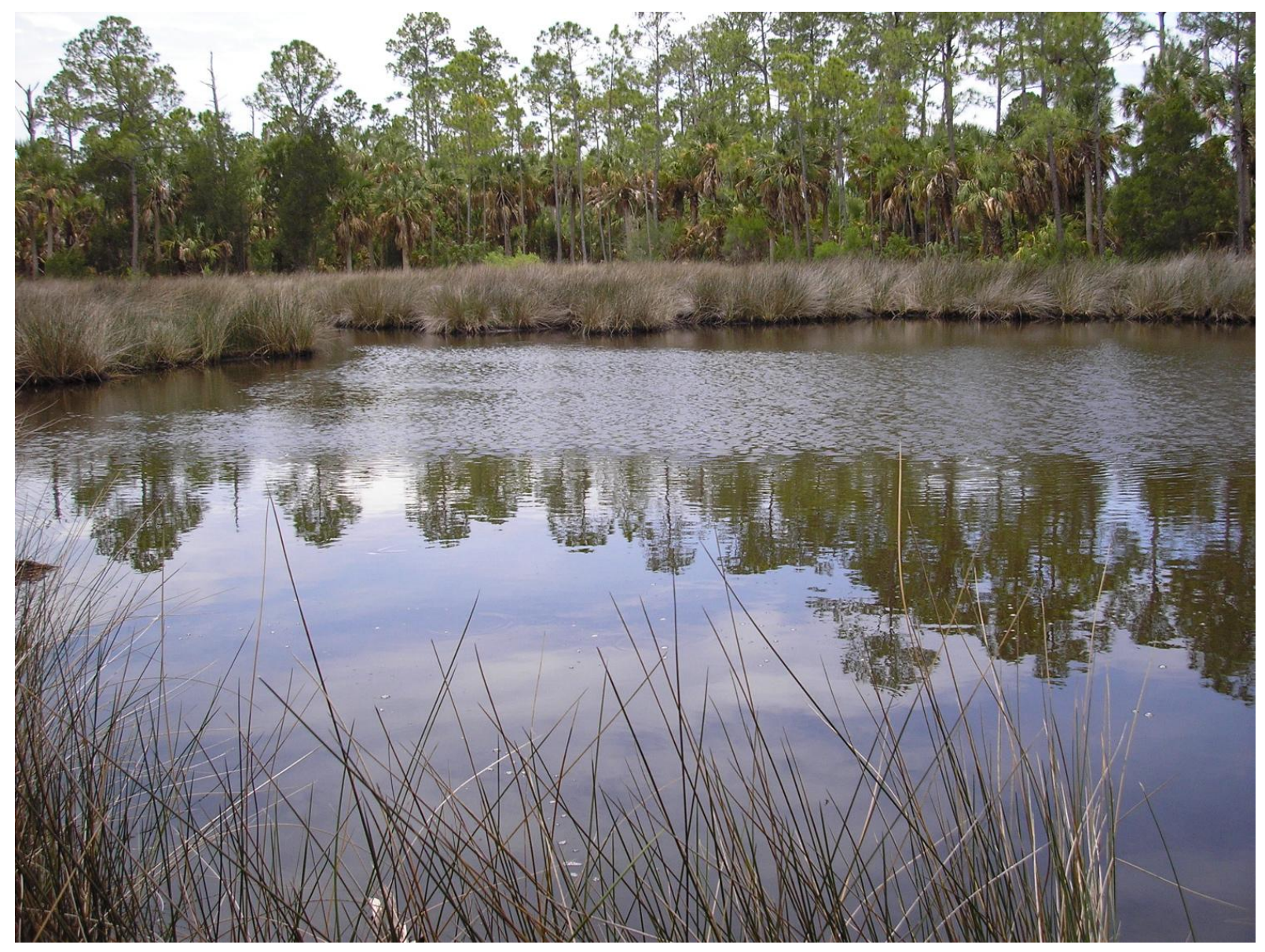

Figure 22. Level 4 pond at Lukens Creek surrounded by high marsh and pine hammocks. 


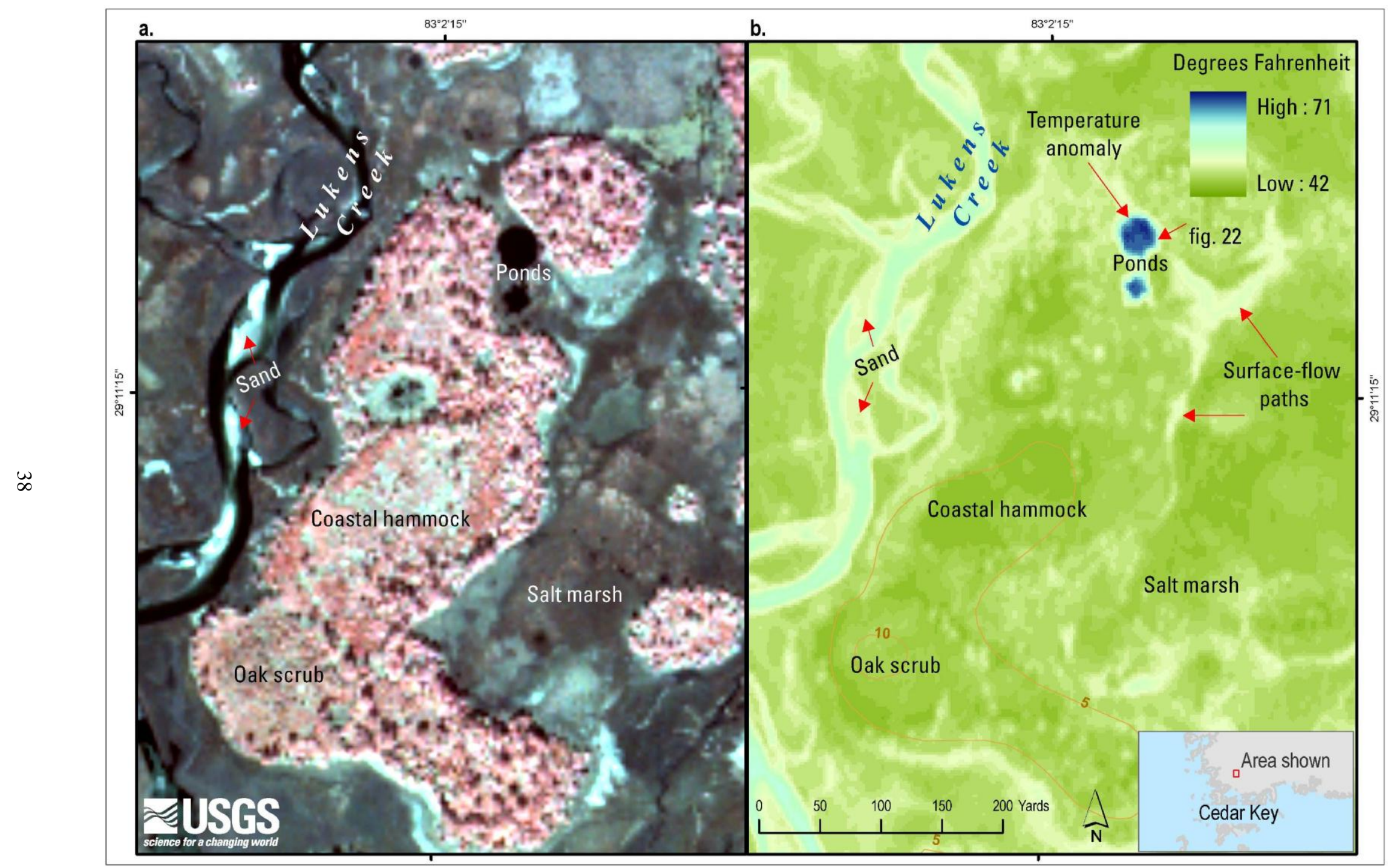

Figure 23. Lukens Creek Level 4 ponds contrast with cooler landscape: a. color infrared, b. thermal infrared. 


\section{Cedar Key}

A mudflat exposed at low tide near Cedar Key is shown in figure 24. The temperature of this feature in 2009 TIR image, 48 to $49^{\circ} \mathrm{F}$, was considerably lower than the ambient temperature of Creek or Bay water, as would be expected from exposed muddy substrate. A small boat embayment nestled between hotels and condominiums is illustrated in figure 25. This shallow, mud-bottomed water feature, at 55 to $56^{\circ} \mathrm{F}$, was in the ambient surface water temperature range for the Creek zone. Both features can be seen in figure 26, showing the east end of Cedar Key with CIR (fig. 26a) and TIR night imagery (fig. 26b). Swimming pools stand out as the warmest features, considerably warmer than either mudflat or boat bay. Notable features in Cedar Key include cool rooftops, warm swimming pools, asphalt roads in the mid-range similar to the creek, and the moderating effect of vegetation over wet ground. Mud and sand features, exposed during low tide in the 2009 night TIR image, reliably exhibited low temperatures within or below the ambient water temperature for Creek and Bay zones.

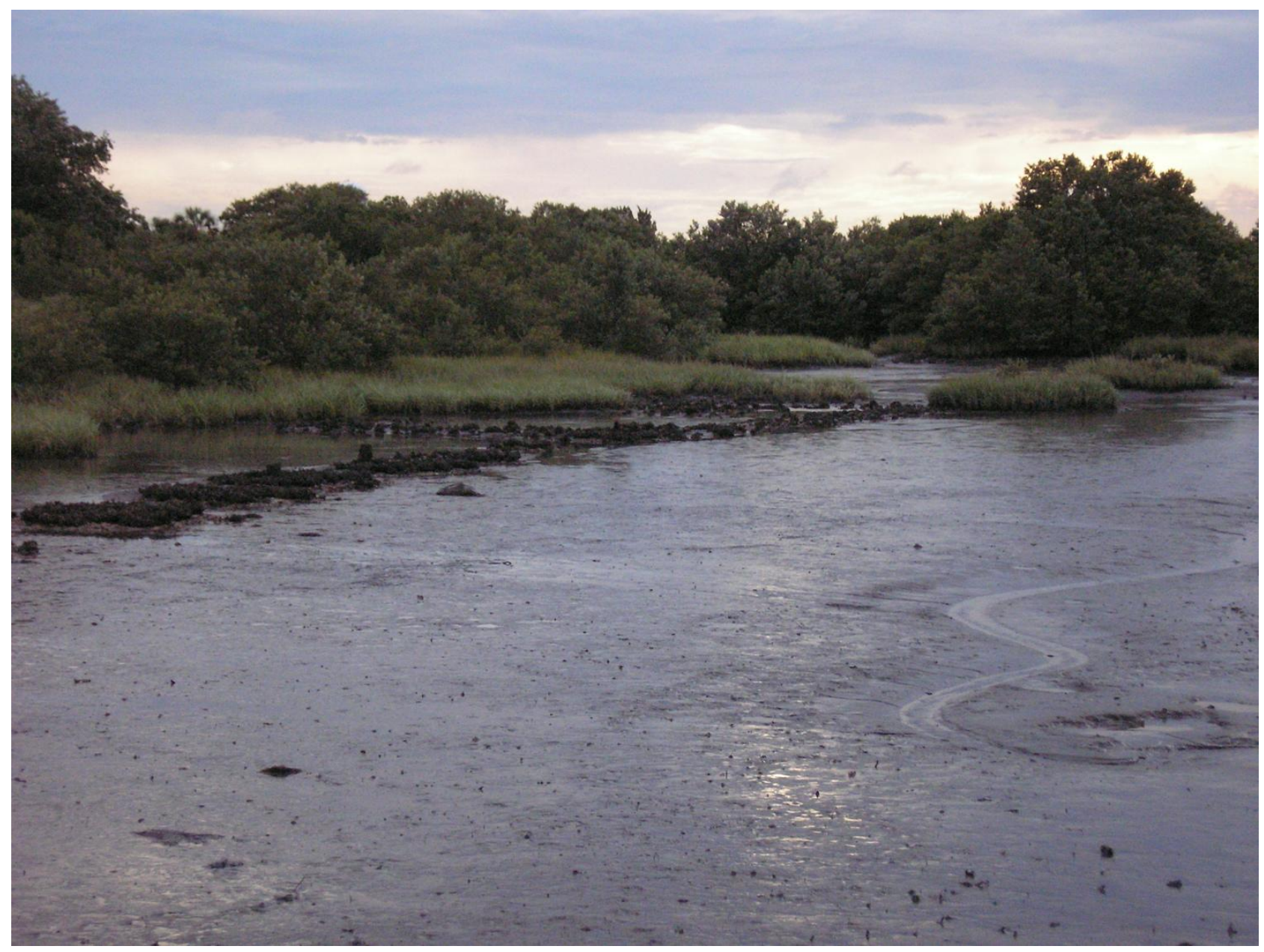

Figure 24. Mudflat near Cedar Key exposed at low tide, looking west. 


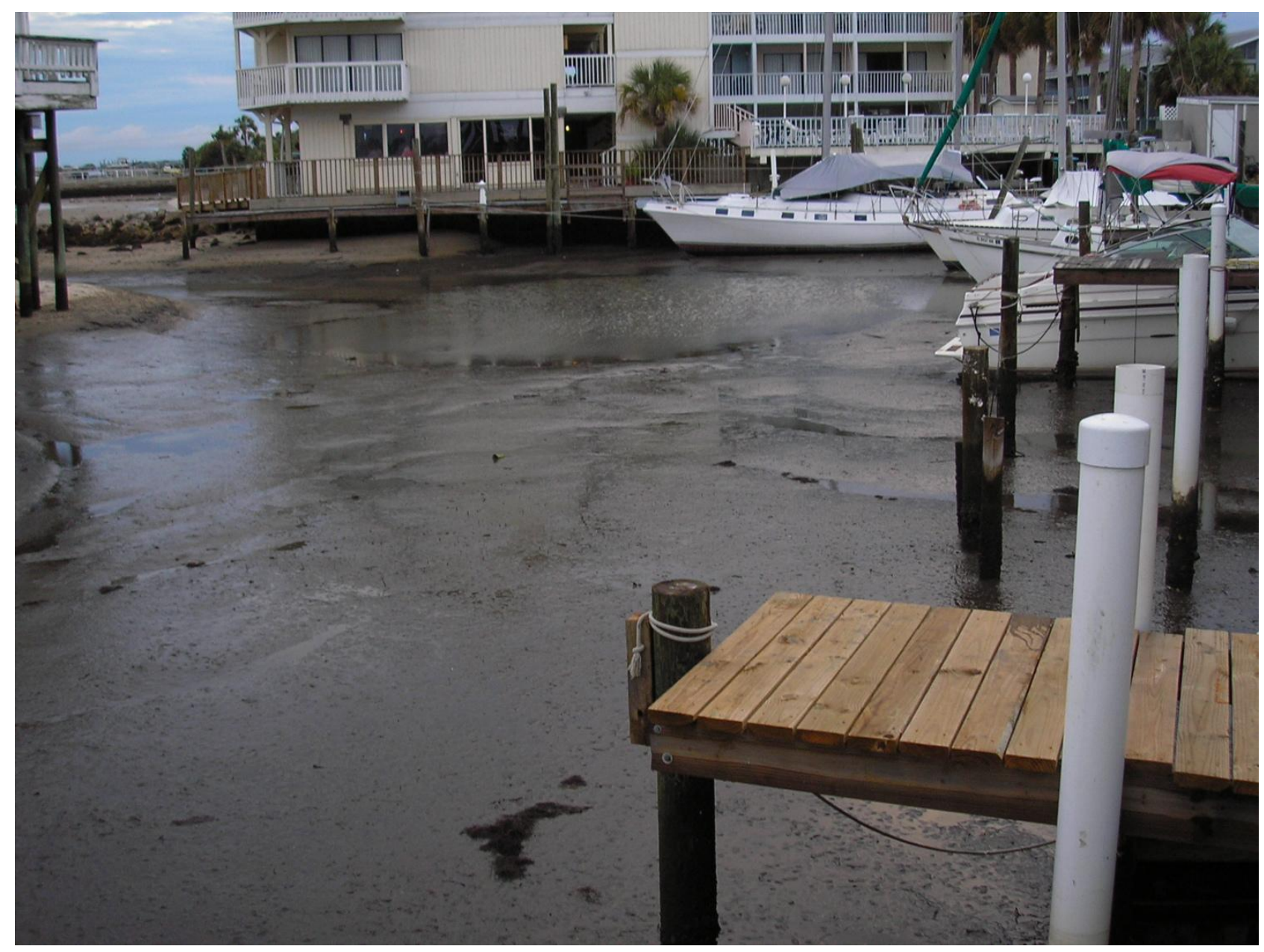

Figure 25. Shallow boat bay between hotels and condominiums in Cedar Key.

Figures 14 and 15, which show Winzy Creek and Waccasassa River, respectively, also depict many depressions, solution holes, and tidal creek drainages, yet only select features display statistically significant temperature anomalies. Warm temperatures surround and exit from high-temperature features. The configuration of warm to cool pixels corroborates the presence of flowing water with emissive power exceeding that of surrounding features. If it were true that warmer temperatures in night imagery indicated release of stored energy from accumulated muddy sediments in depression features, then most depression features in the imagery would emit a contrasting thermal signal, because mudbottomed depressions are ubiquitous to this region. 


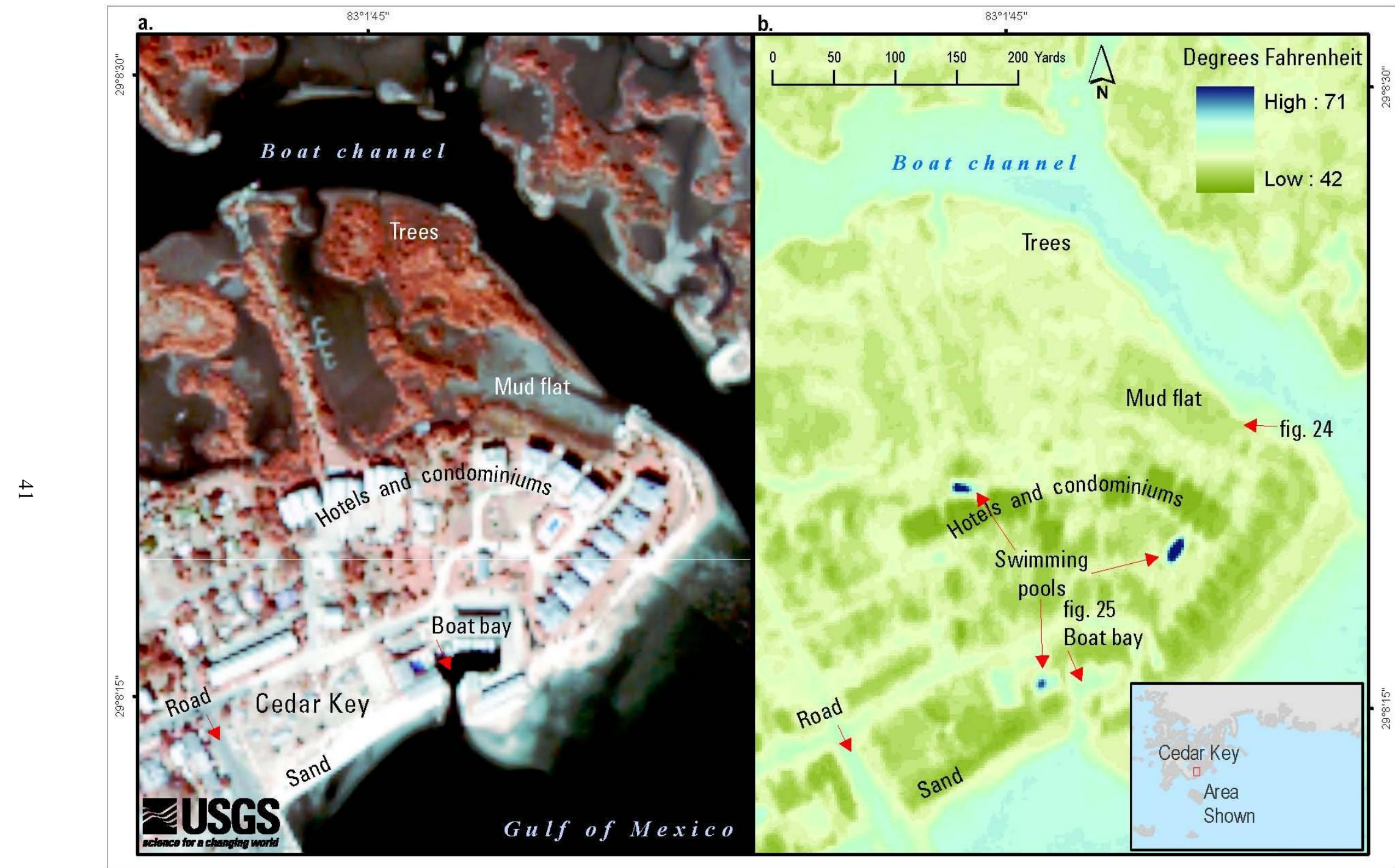

Figure 26. Cedar Key swimming pools are Level 4 sites: a. CIR, b. TIR. 


\section{Thermal Infrared Versus Field Reconnaissance}

Three areas were selected to illustrate the variety of Level 4 temperature anomalies in the TIR imagery: Jacks Creek, excavation pits near Waccasassa River, and Beetree Slough area.

\section{Jacks Creek}

An area near Jacks Creek demonstrates the difficulty comparing what is visible to the eye and what can be detected with TIR imagery (figs. 27-33). Figure 28 illustrates Jacks Creek area with CIR (fig. 28a) and TIR night imagery (fig. 28b). Vague traces of dirt roads can be seen in the imagery and only minor temperature differences can be detected between marsh and forest. Ten Level 4 temperature anomalies were mapped among many pond and depression features, most not thermally different from Creek-zone background temperature. Arrows on figure 28b indicate photos taken at Level 4 sites (fig 27 and 29), a Level 1 site (fig. 30) and ponds with no temperature signal (figs. 31-32). Jacks Creek area is primarily coastal forest with creeks, exposed rock, depression features, and tidal marsh toward the coast. Photographs illustrate the difficulty in making visual distinctions in the field based on water clarity and the variety of pond depths, exposed limestone, and persistent mud deposits observed at depressions in the region (figs. 27, 29-33).

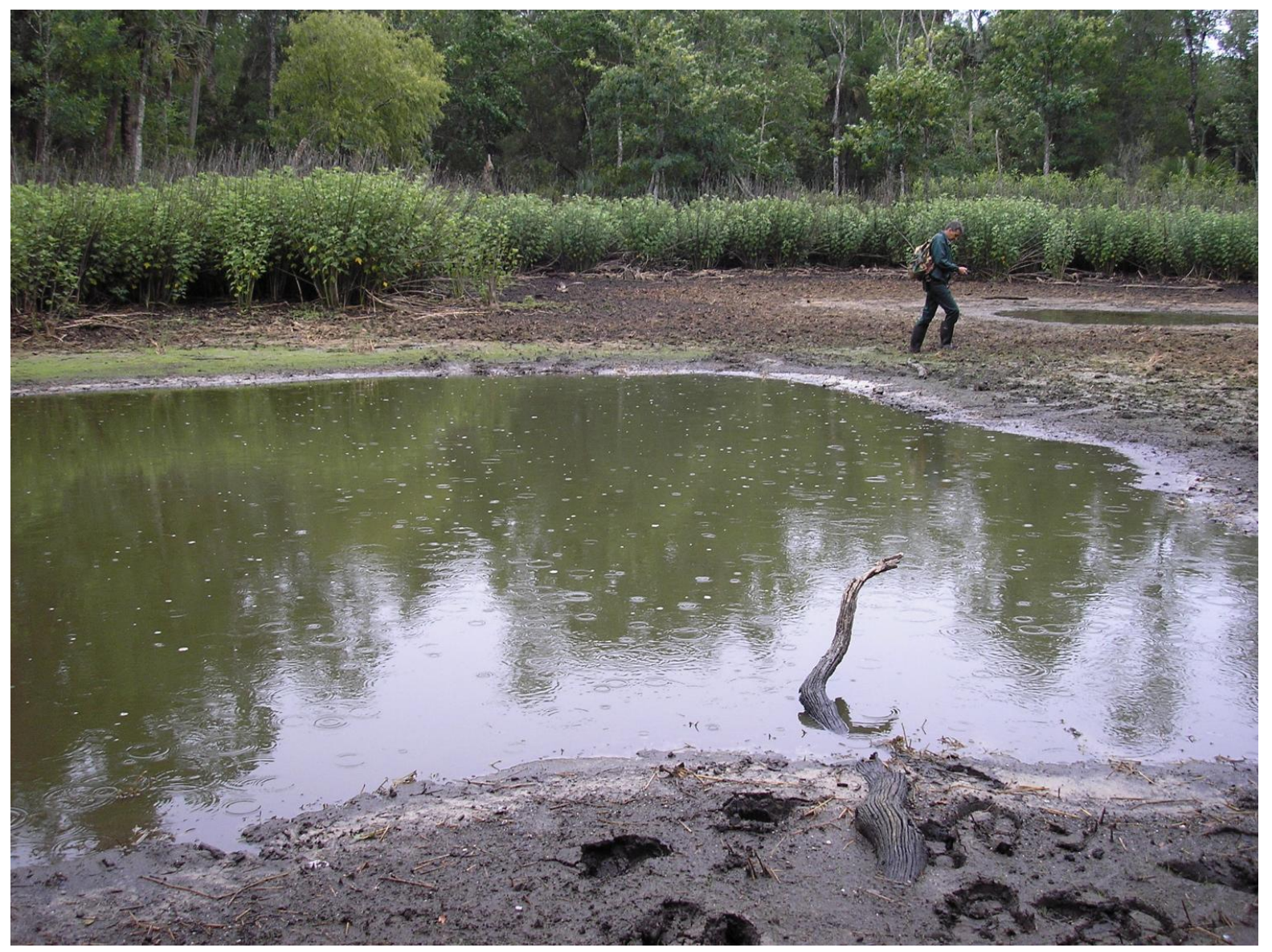

Figure 27. Jacks Creek Level 4 twin ponds in dry season with corkwood at perimeter of two mud holes in May 2009. Photo looking south. 


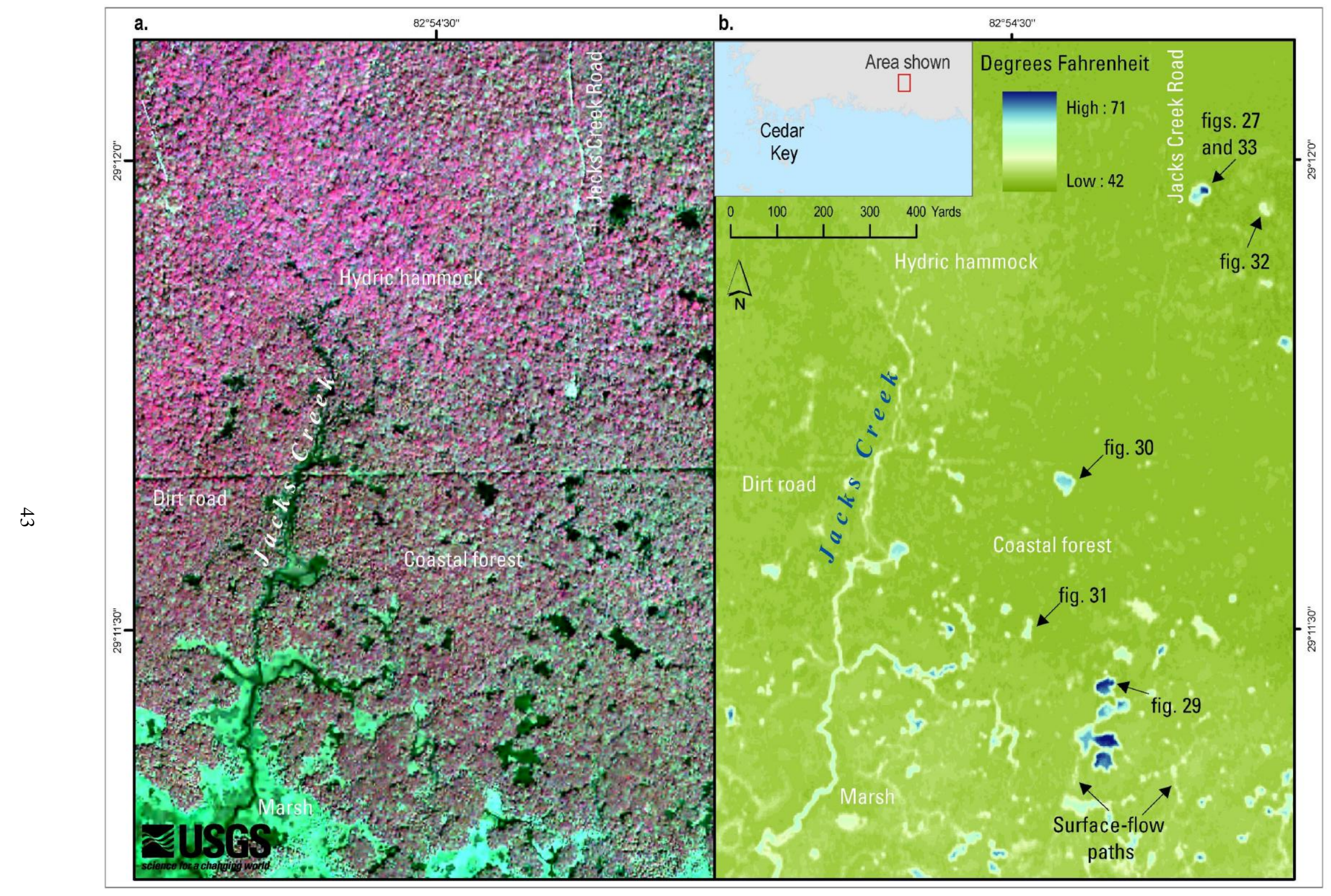

Figure 28. Jacks Creek a. CIR image, b. TIR image shows Level 4 ponds in contrast with ambient temperature in ordinary depressions. 


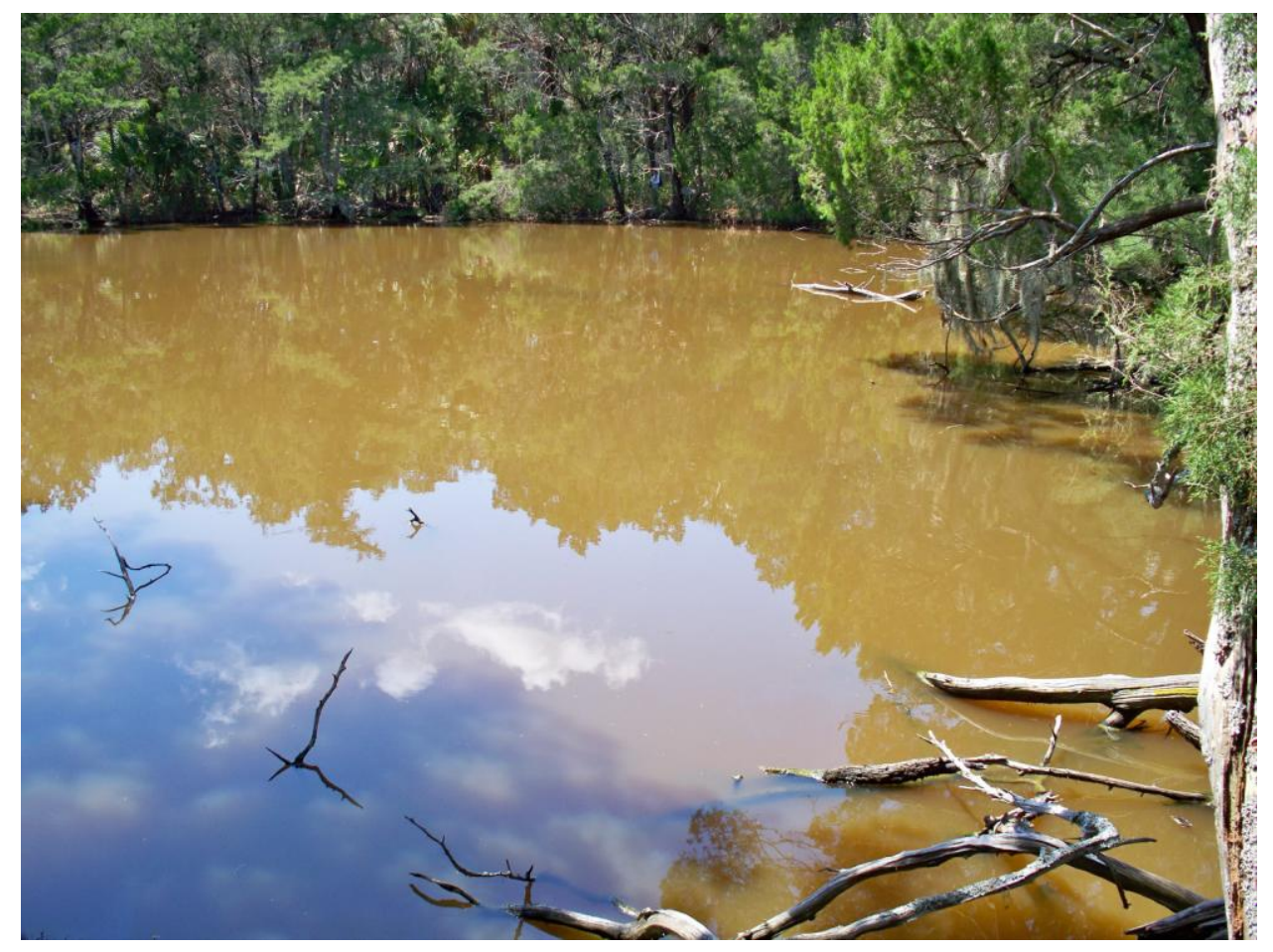

Figure 29. Level 4 site near Jacks Creek with murky rust-colored water and bird rookery.

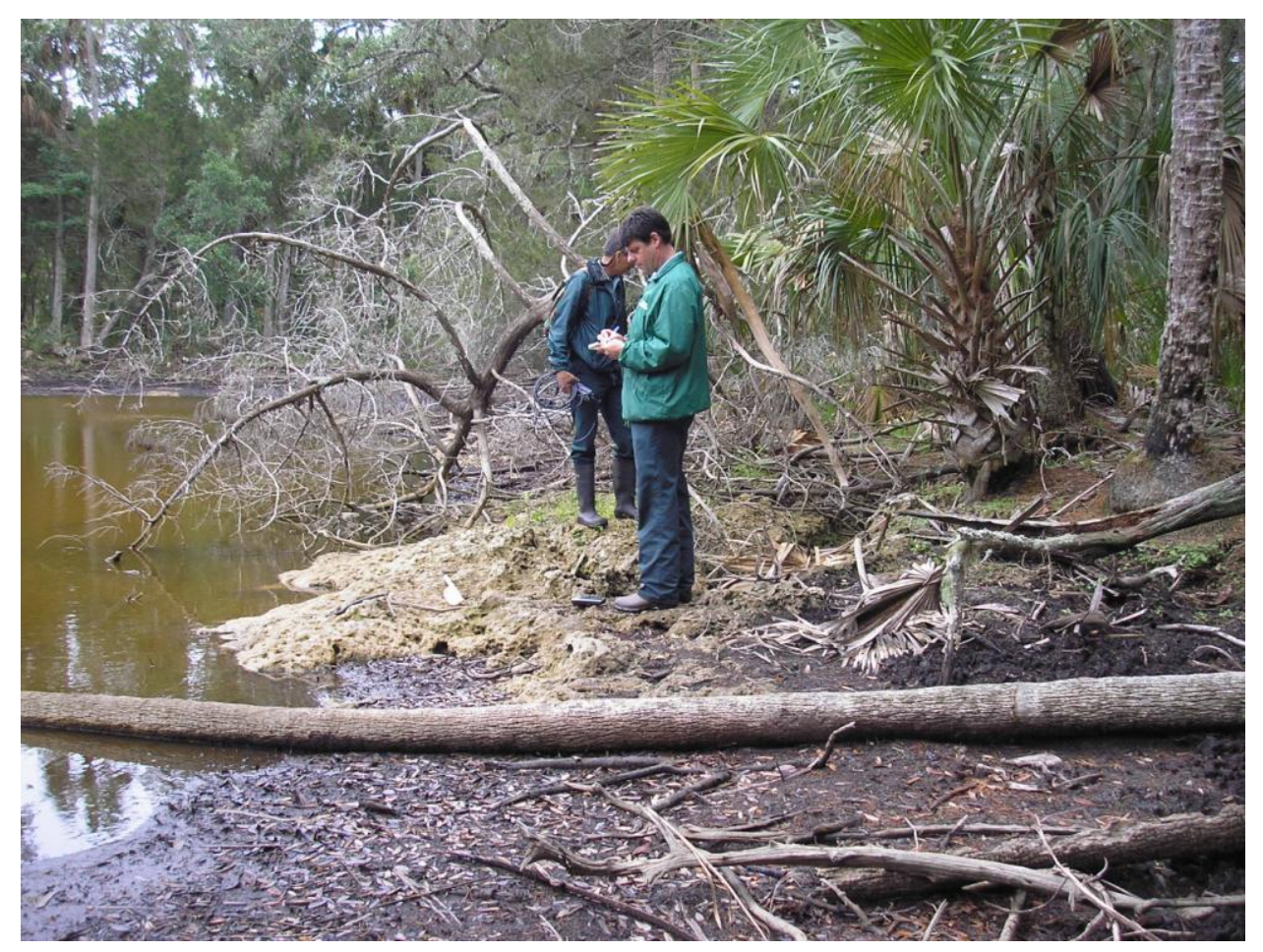

Figure 30. Large Level 1 limestone-rimmed pond near Jacks Creek with alligators in rock caverns. State employees making observations and water-quality measurements. 


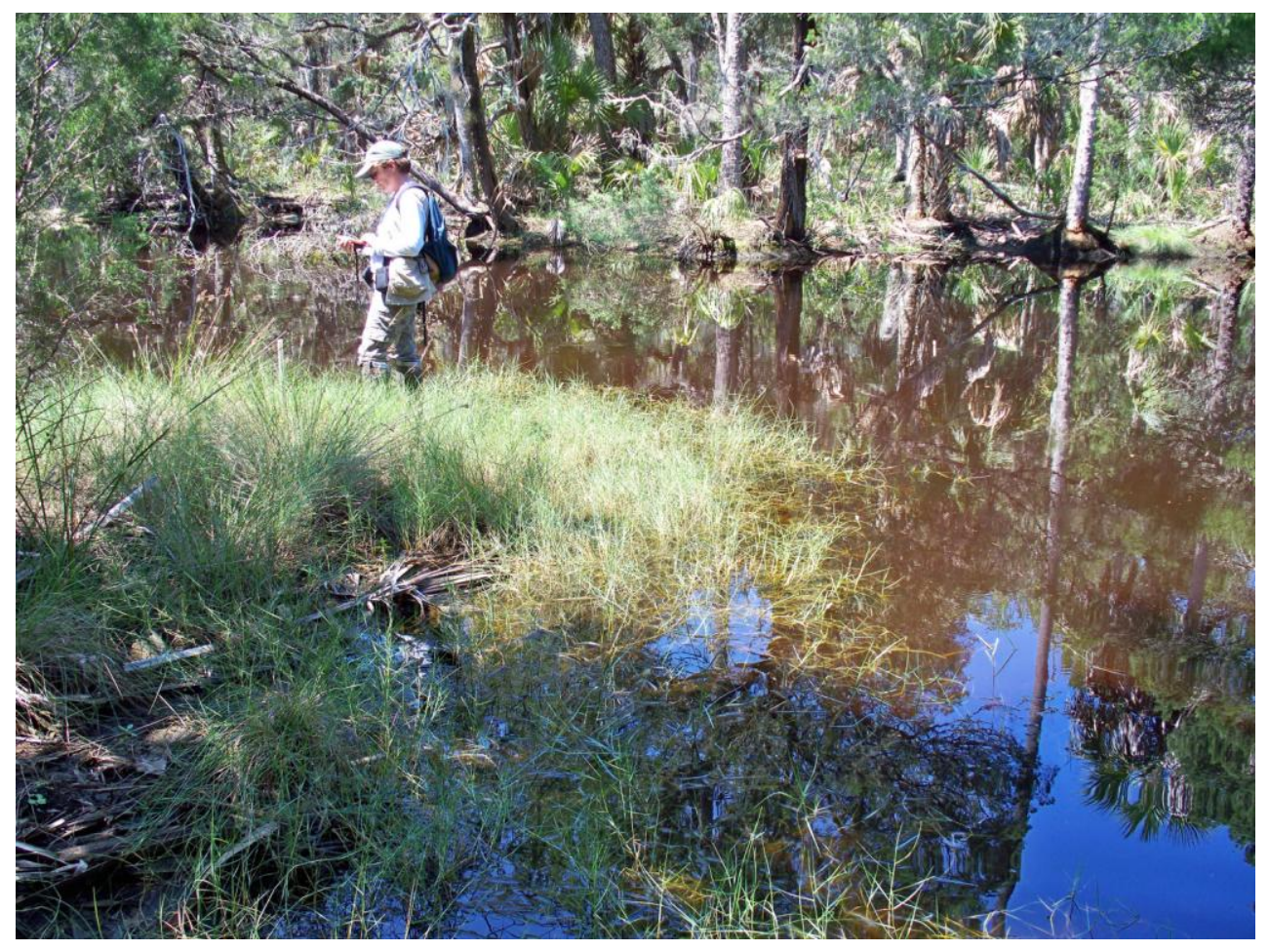

Figure 31. Control site near Jacks Creek with murky water, mud bar, marsh and coastal forest. USGS scientist confirming GPS position.

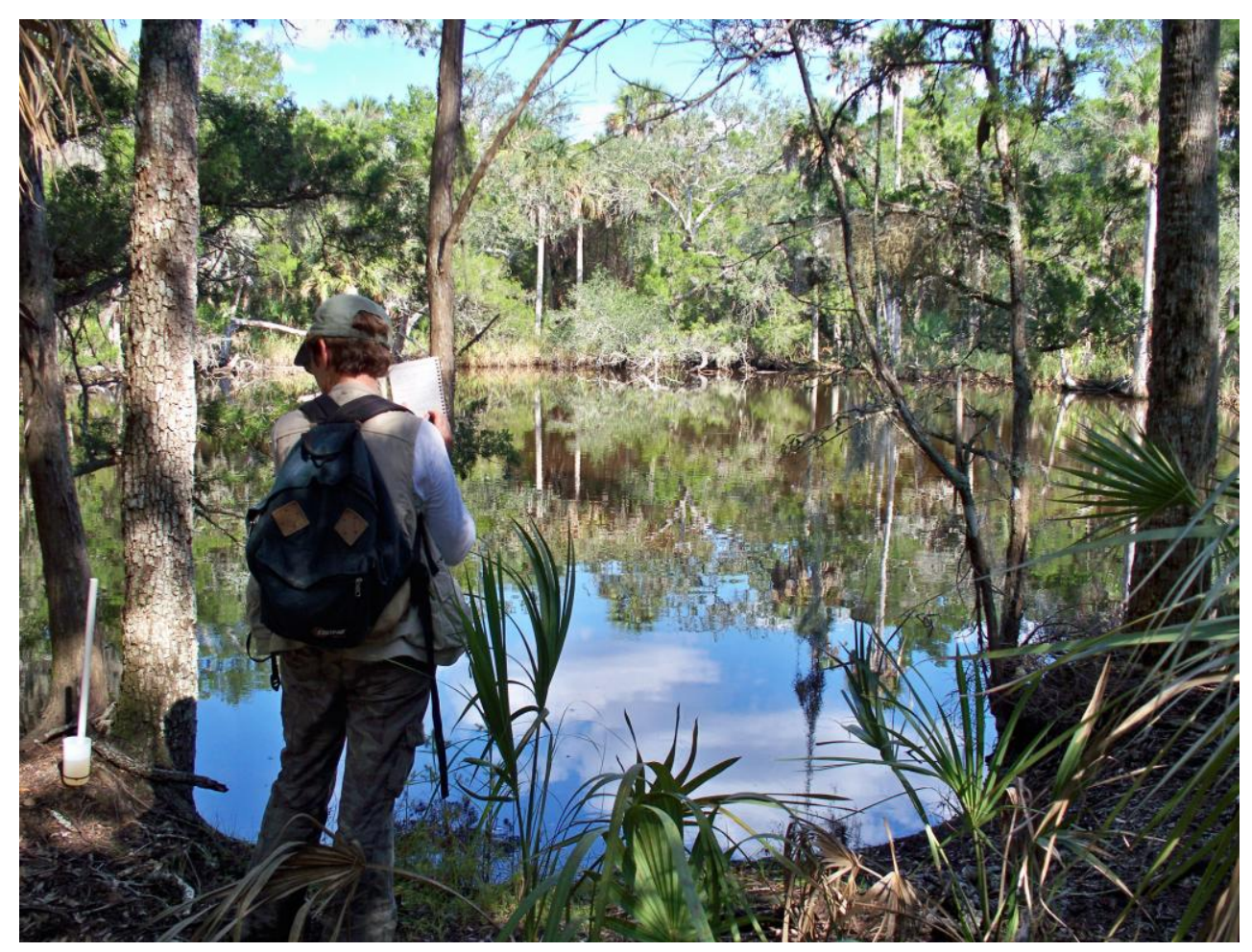

Figure 32. USGS scientist at control site 100 yds east of Jacks Creek twin ponds (fig. 27), 
Although time of year and groundwater conditions can have a significant impact on field assessments, TIR imagery can be used to pinpoint an otherwise unidentifiable site. Figure 27, a Level 4 site, consisted of two pools of muddy water in a large muddy depression with animal tracks, carcasses, and droppings in May 2009. The area was clearly frequented by a variety of wildlife, including large alligators and feral hogs, but otherwise did not appear to be a seep despite the TIR temperature anomaly. A band of corkwood and marsh mallow stood on high ground around the perimeter of the feature. Figure 33 shows the pond in the wet season during September 2009. The fully flooded ponds appeared healthy, and shallow water spread to the corkwood perimeter. Two distinct clearings appeared on the water surface in the same location as the two muddy pools photographed in May (fig. 27).

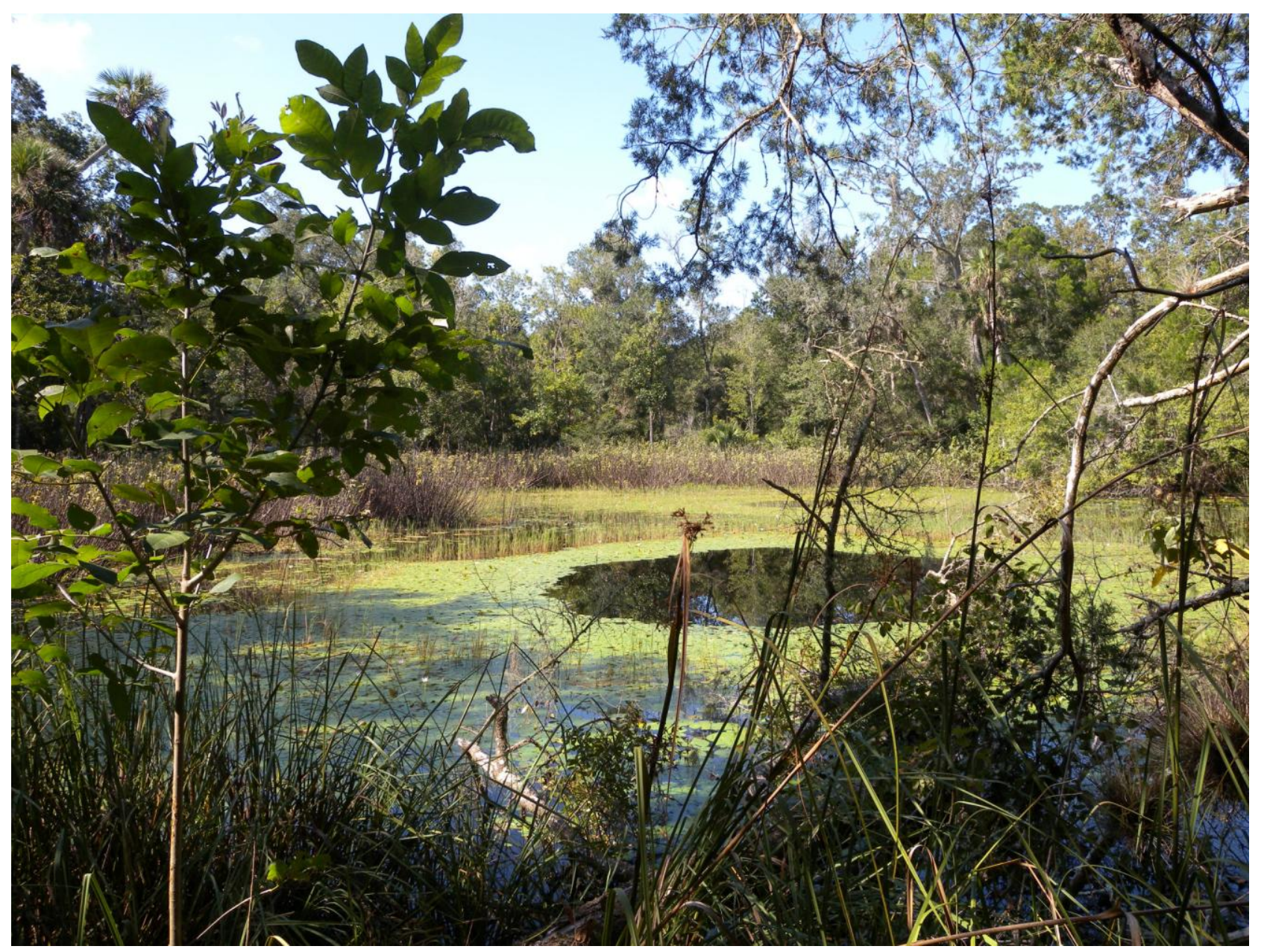

Figure 33. Jacks Creek twin ponds September 2009 flooded to corkwood perimeter with two water-surface clearings at location of May mud holes. Photo looking south. Compare to fig. 27.

The benefits of field observations include opportunities to observe a feature during different tidal cycles, seasons, and groundwater levels. However, field reconnaissance is limited to observations of single features, one at a time, and discharge vents may be inaccessible for direct measurement. If a vent is not at the edge of a feature, the actual measurement location may represent a mixing of groundwater flow with surface water, revealing water quality or temperature that does not reflect groundwater seepage. Airborne imagery can capture all features at a given instant and provides a geographically comprehensive view of the landscape that is not limited to feature edge or accessible depressions. 
Tidal creeks and isolated karst ponds generally reflect diurnal warming and cooling patterns in March, as noted in the low ambient surface-water temperature of the Creek zone (table 3). Although identifiable flow would not be expected at all discharge sites under 2009 hydrologic conditions, it is not likely that reverse flow was observed, considering the low tide during image acquisition (fig. 10). However, the impact of seawater intrusion was observed in the field. Field observations of estuarine salinities in depression features may be attributed to one or more factors. The variable nature of ponds, depressions, and small waterways may produce similar water-quality measurements through different processes. Those surface-water features not currently connected to groundwater flow will receive freshwater through precipitation and surface flow and seawater by way of surface flow at high tide, if close to the coast. A deposit of impermeable fine sediments may line the bottom of these features, increasing retention and eliminating the possibility of flushing through karst conduits. Thus, during prolonged dry periods, the retained surface water may exhibit seawater salinities in a non-vented depression. Vented features, on the other hand, collect and release freshwater through both surfacewater and groundwater flow. Seawater may enter a vented feature by way of surface flow at high tide, through conduits when groundwater levels are low, or as re-circulated seawater along preferred flow paths. Thus, a vented feature may exhibit seawater salinities, despite flushing capacity of karst conduits. Figure 34 shows a solution hole near Jacks Creek in the Beckwell area (fig. 21) with fresher water (4 ppt) and aquifer temperature at 6.5-ft depth in May 2009, contrasting with 21-22 ppt in surrounding depressions.

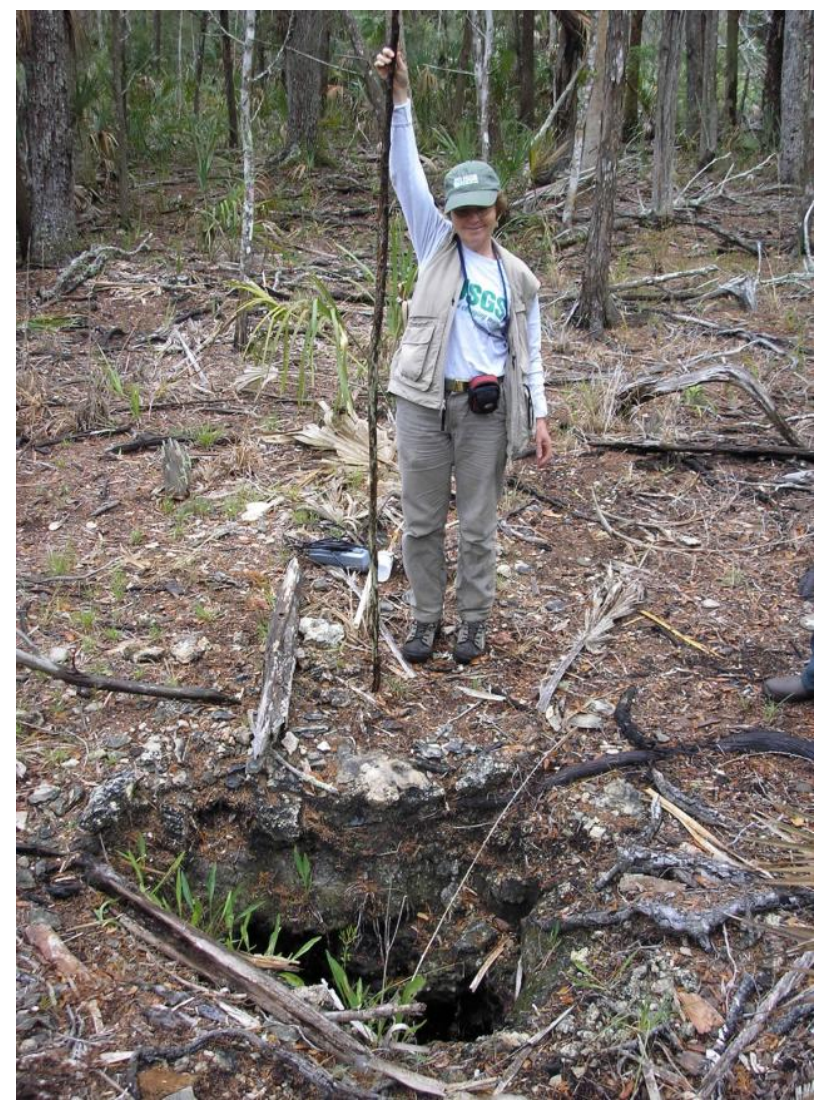

Figure 34. Solution hole near Jacks Creek: water surface $3 \mathrm{ft}$ below ground surface, $4 \mathrm{ppt}$ and $71^{\circ} \mathrm{F}$ at depth, May 2009. 
The area around Beckwell and Squarewell (fig. 21) is riddled with solution holes and depressions of varying size, depth, and character. The higher salinities in nearby ponds imply that variable and unique conduits and impermeable sediment layers may result in adjacent but very different groundwater movements, reverse flow, flushing, and surface-retention patterns. Biogeochemical processes and the interaction of fresh and saltwater produce variations in color, clarity, and material in solution. Wildlife activity on the ground and contribution from decaying organic matter may further confuse the issue. Yet the TIR imagery successfully captured thermal contrasts in the landscape, providing clues to the underlying geologic structure and subterranean flow.

\section{Excavation Pits}

Figure 35 depicts a large excavation site east of Waccasassa River and Cow Creek. The surface water was deep and fresh and the surrounding landscape was a combination of silviculture, roads, and second-growth forest. The headwaters of Bullfrog Creek can be seen in the upper left corner of figure 36a with the distinct signature of marsh leading into a wooded swamp. A faint temperature signal shows in the TIR imagery in a depression north of the excavation site (fig. 36b), but the primary thermal target in this area is the excavation site itself (fig. 35). Many borrow pits in the region showed multiple, significant, Level 4 temperature anomalies.

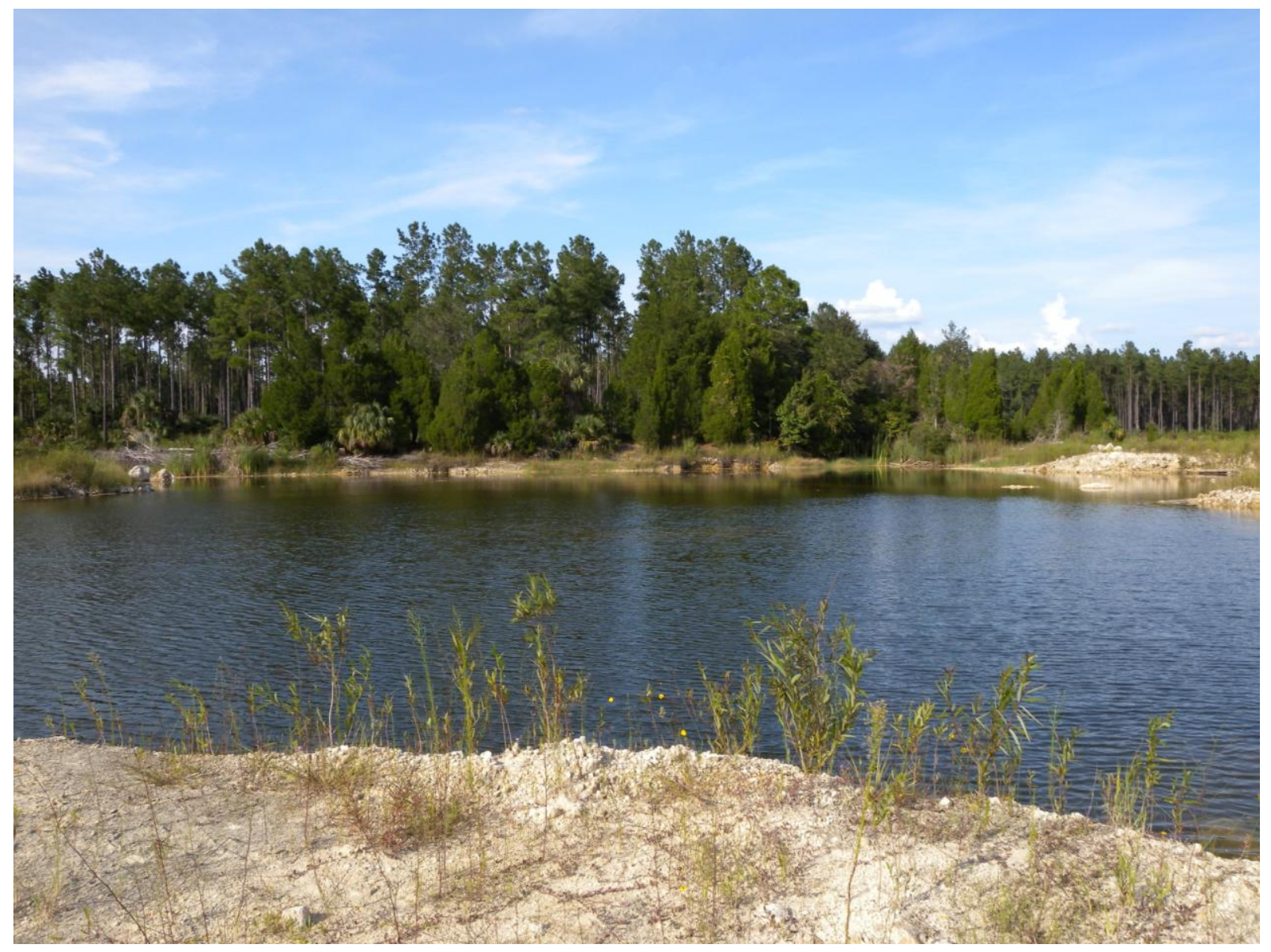

Figure 35. Excavation pits on Robinson Rd. with freshwater and large Level 4 thermal anomalies. 


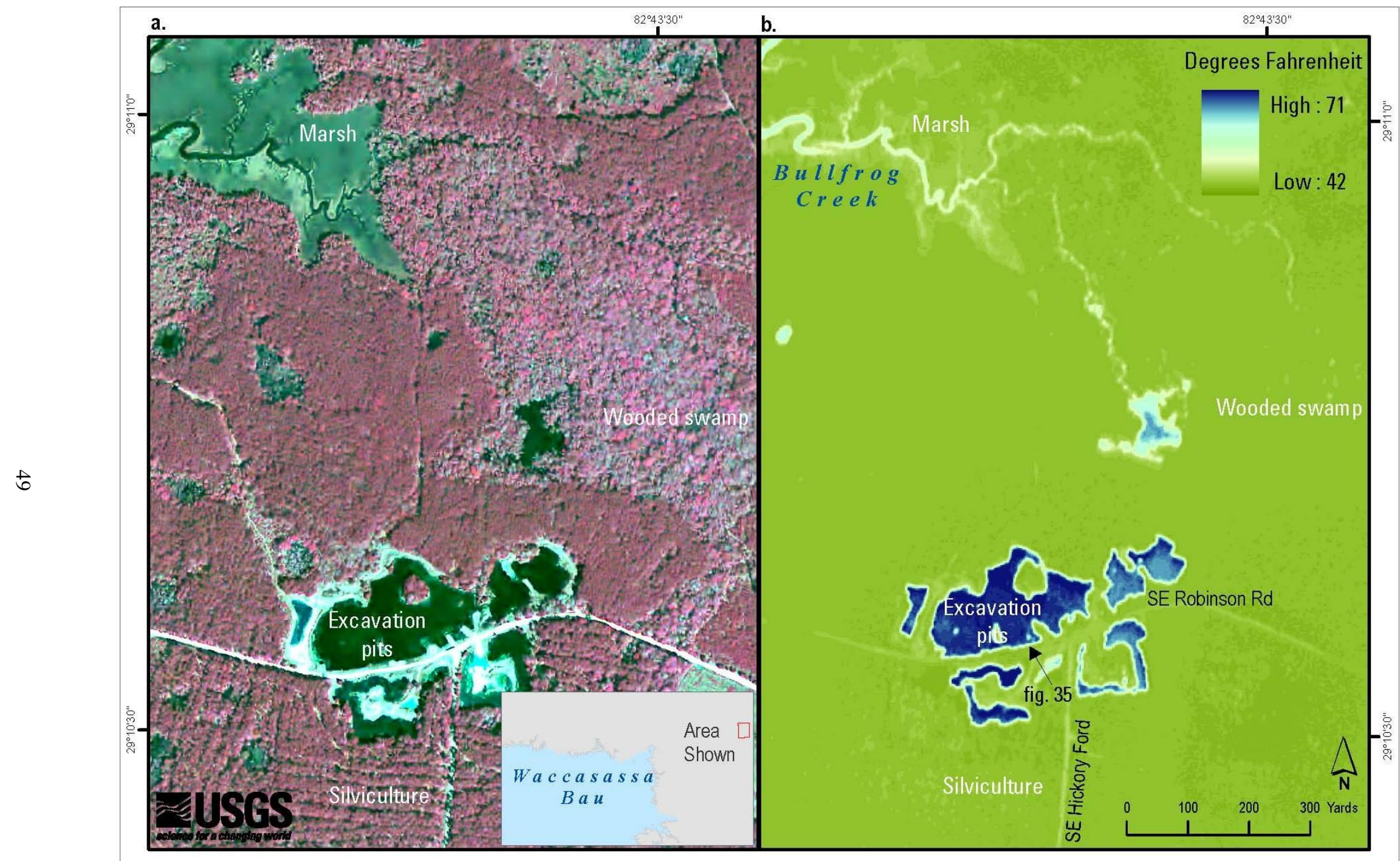

Figure 36. Water-filled excavation pits near Cow Creek had large temperature anomalies, a. CIR, b. TIR. 


\section{Beetree Slough}

A series of small thermal features dots the landscape from Waccasassa River south to Withlacoochee River. Many of the thermal signals were in surface-water bodies near the marsh and forest boundary, approximately $1.5 \mathrm{mi}$ from the coast. Examples of these features are shown in figures 37-41, an area near Beetree Slough. Limestone exposures, muddy sediments, tall coastal-forest canopy, and various emergent, submerged, and floating aquatic-vegetation communities were common. Although the ponds appear relatively isolated, they are connected by shallow surface waterways during high-water intervals, as indicated by the white/tan-color pathways (fig. 38). The landscape is a fragmented series of hammocks, karst surfaces, depressions, creeks, marsh, and areas of downed trees (fig. 41). Anecdotal evidence of a large seep at Turtle Creek spurred an earlier investigation that identified traces of a thermal signal in daytime TIR (Jeff DiMaggio, Florida State Park Service, oral commun., 2002; VeriMap, 2002). The feature was not corroborated with this mission, but it remains a possibility in future work during periods of relatively high groundwater levels.

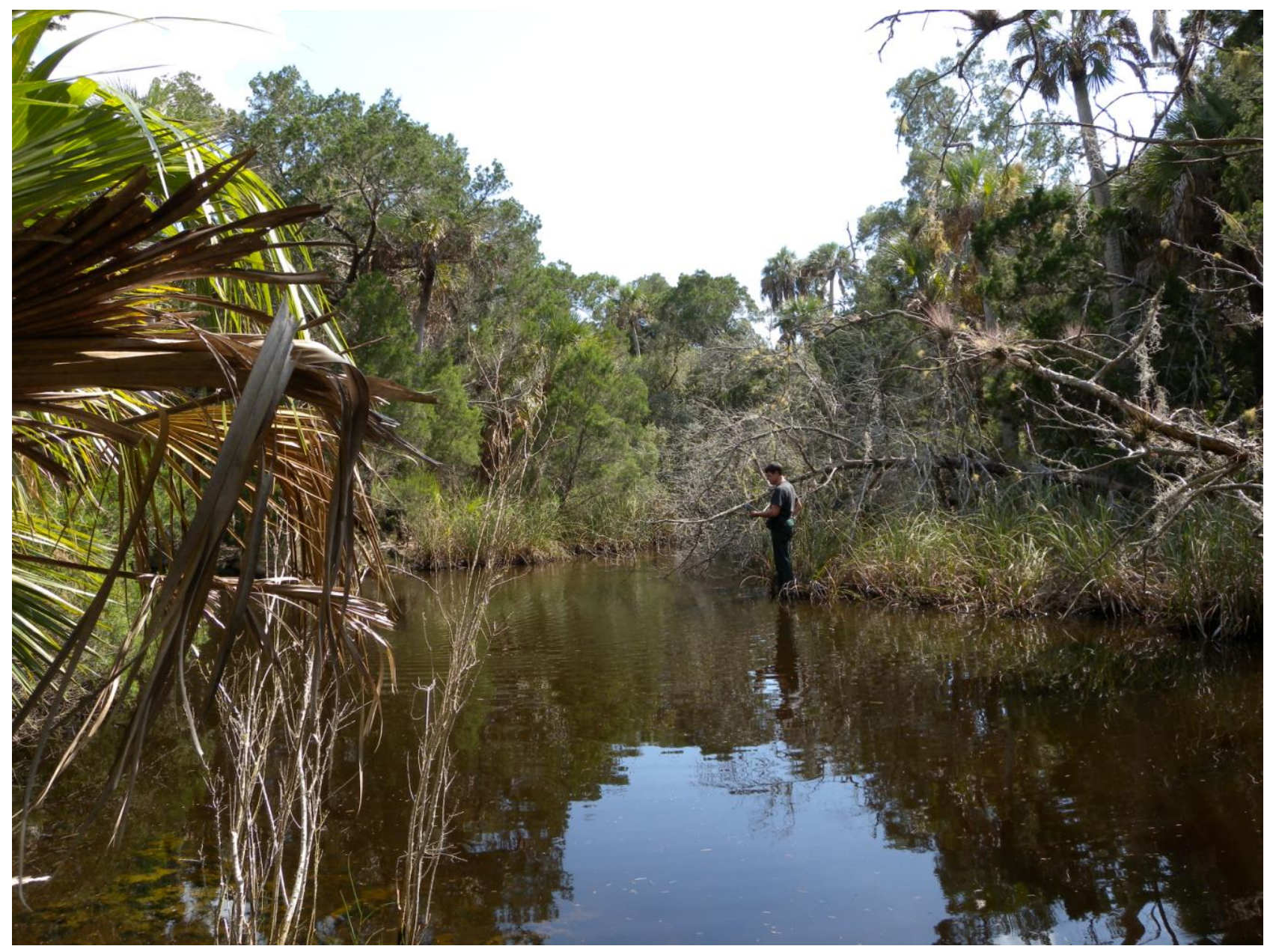

Figure 37. Irregularly shaped, limestone-lined, Level 4 pond with deep pool near Beetree Slough. 


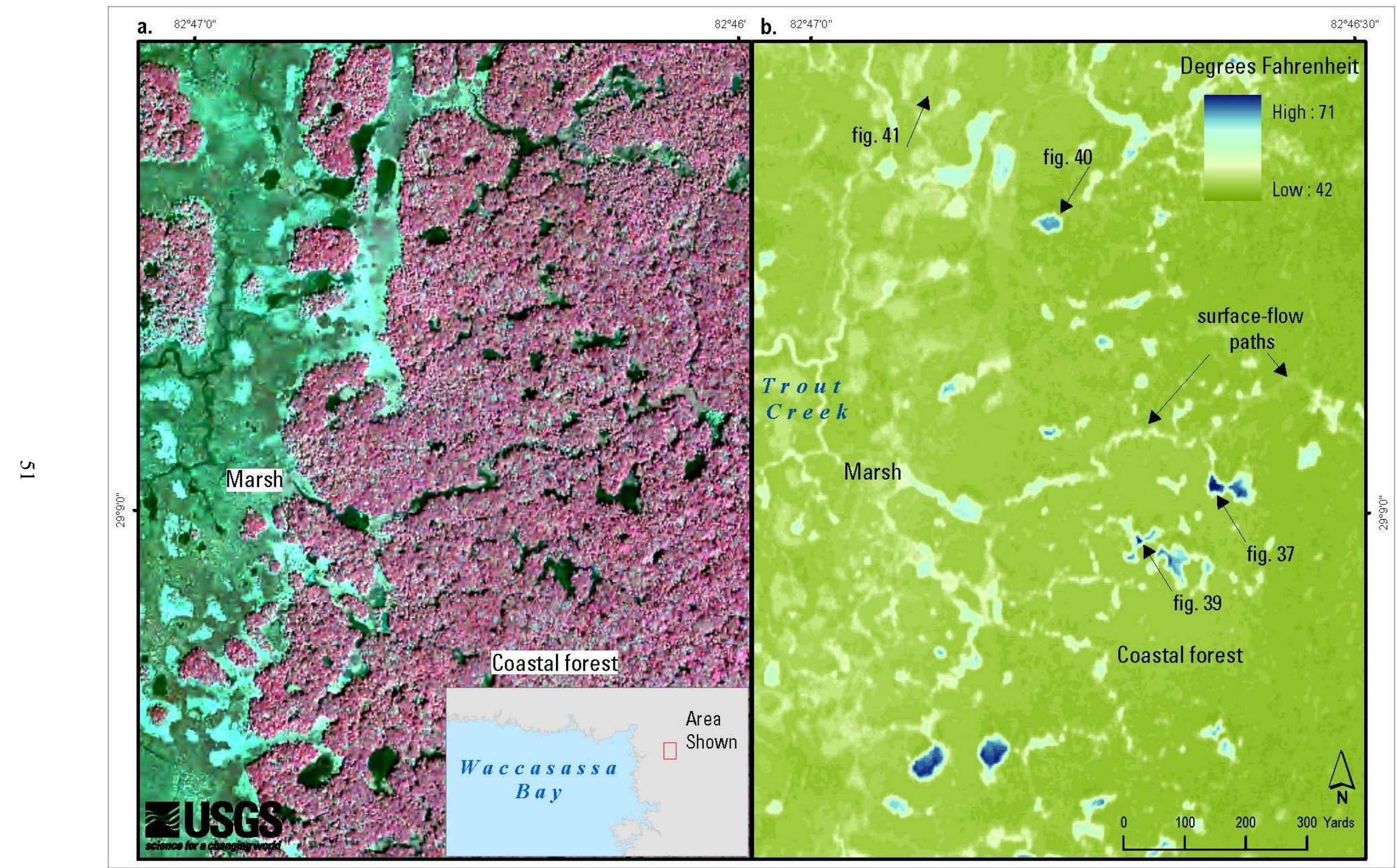

Figure 38. Temperature anomalies at the marsh and forest boundary near Beetree Slough, a. CIR, b. TIR. 


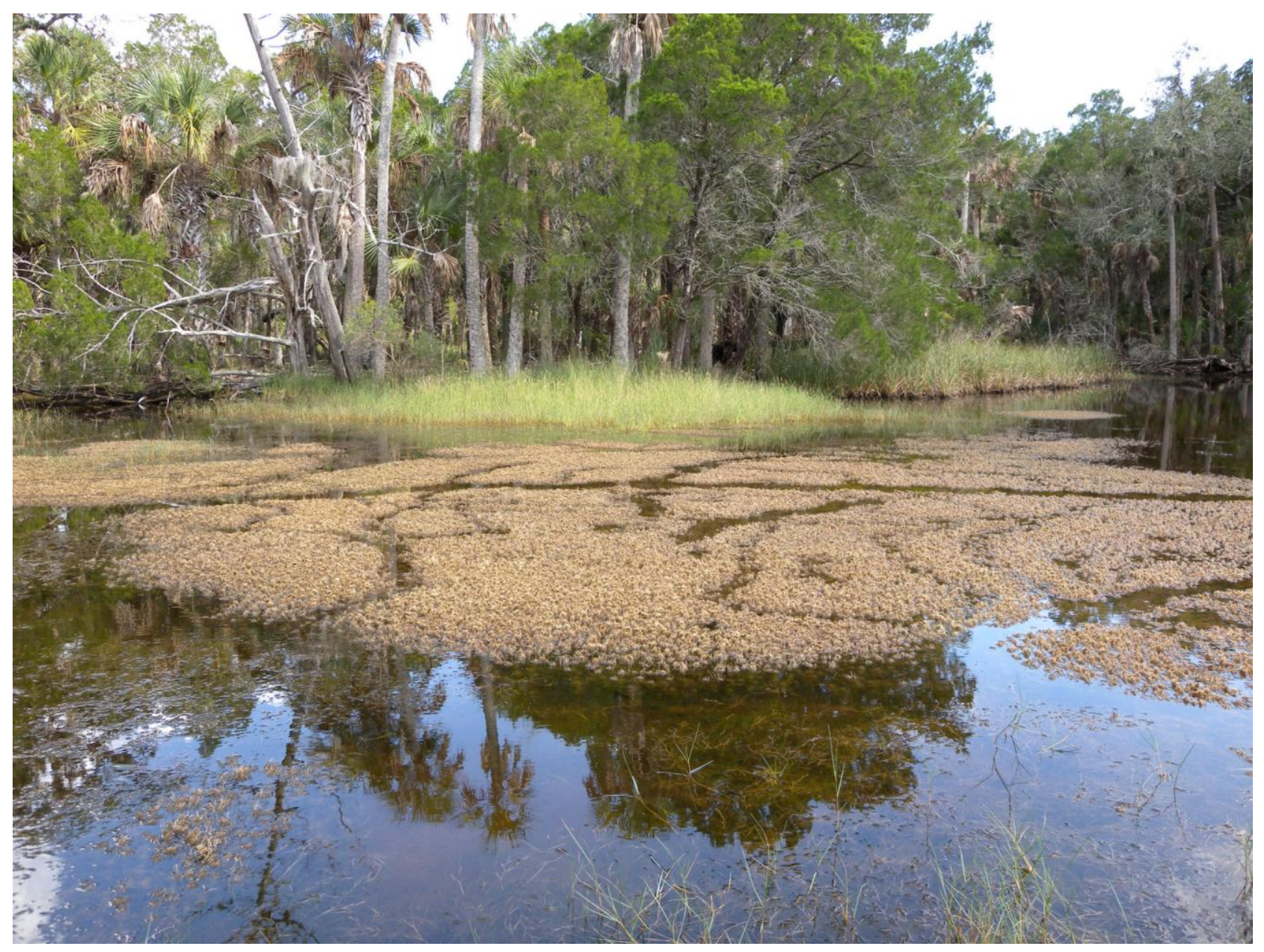

Figure 39. Level 4 pond near Beetree Slough with aquatic plants, rock exposures, and coastal forest.

\section{Influence of Underlying Geology}

Significant temperature anomalies displayed linear and asymmetric geographic patterns. Level 4 anomalies were warmer by $9.5^{\circ} \mathrm{F}$ or more over ambient Creek temperature, and warmer by $5.5^{\circ} \mathrm{F}$ or more over ambient Bay or Gulf temperatures. Level 1 to 3 features are indicative of relative size or impact region of discharge, and may guide further investigations into the regional structure of subterranean dissolution channels. Differences in surface expression and the size, number, and proximity of vents may be attributed to variations in limestone characteristics, porosity, conduit depth, and fracture patterns. Where many seeps occur in close proximity, high connectivity and interdependent groundwater-flow paths may be present. Where seeps occur in isolation, underlying conduits may be deeper or groundwater flow may be constrained by unique pathways or separated by impermeable layers.

An analysis of the directional distribution of natural seeps produced a trend ellipse parallel to the northwest fault strike (Prowell, 1983; fig. 17). The occurrence of discharge features along fault and fracture lines has been documented along the Suwannee River (Beatty, 1977), in northeast Florida (Kindinger and others, 2000), and in the coastal Mediterranean Sea (Shaban and others, 2005). Recently formed (in geologic time) depressions typically show preferential expansion along dominant fracture 
patterns (Denizman and Randazzo, 2000; Kindinger and others, 2000; fig. 3). Features concentrated along Winzy Creek were positioned in line with the fault-strike direction (fig. 17). The submarine feature extending southwest from Waccasassa River into Waccasassa Bay is at a right angle to the fault line, indicative of a secondary fracture pattern (Vernon, 1951).

Remote detection of aquifer discharge or vent sites does not confirm or evaluate water quality at those locations. For this reason, a second consideration of flow through water-bearing limestone warrants mention. Aquifers bear water from various sources and of various ages (Davis and others, 2001; Katz and others, 2005). Discharge of recirculated and geothermally heated seawater was documented along the central axis of the Floridan Plateau on Florida's Gulf Coast near Fort Myers (Kohout, 1967; Kohout and others, 1977; Hughes and others, 2007). Kohout (1977) showed the Floridan Plateau central axis extending northward and running directly through the Cedar Keys. It was hypothesized that recirculated seawater may discharge from other vents along the Floridan Plateau central axis. The Cedar Keys represent the northern intersection between terrestrial and Gulf influences along this axis. Two large submarine thermal anomalies were identified to the east (Corrigan Reef) and to the west (No. 4 Channel) of Cedar Key in this study.

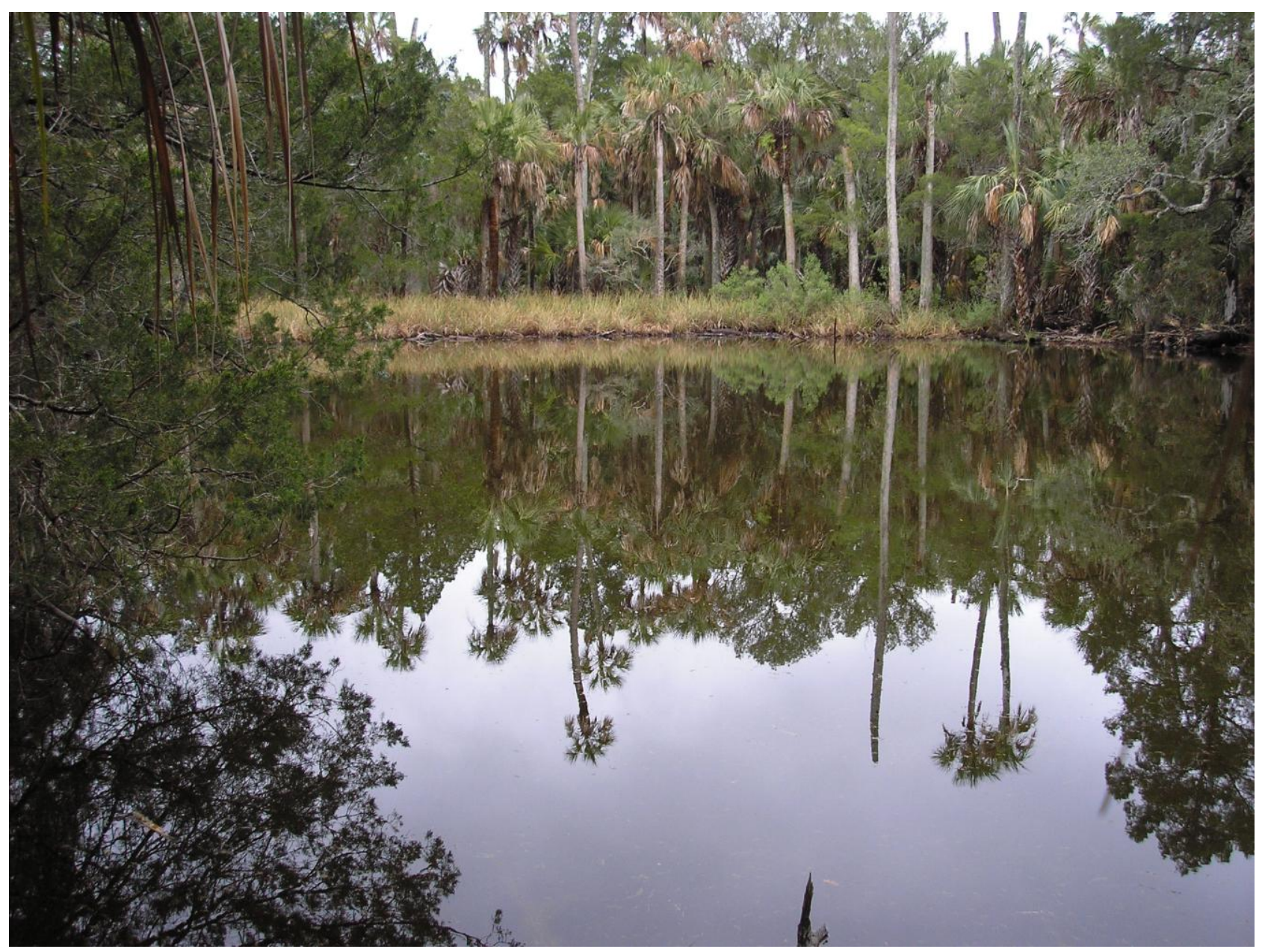

Figure 40. Level 3 pond near Beetree Slough surrounded by coastal forest and high marsh. 


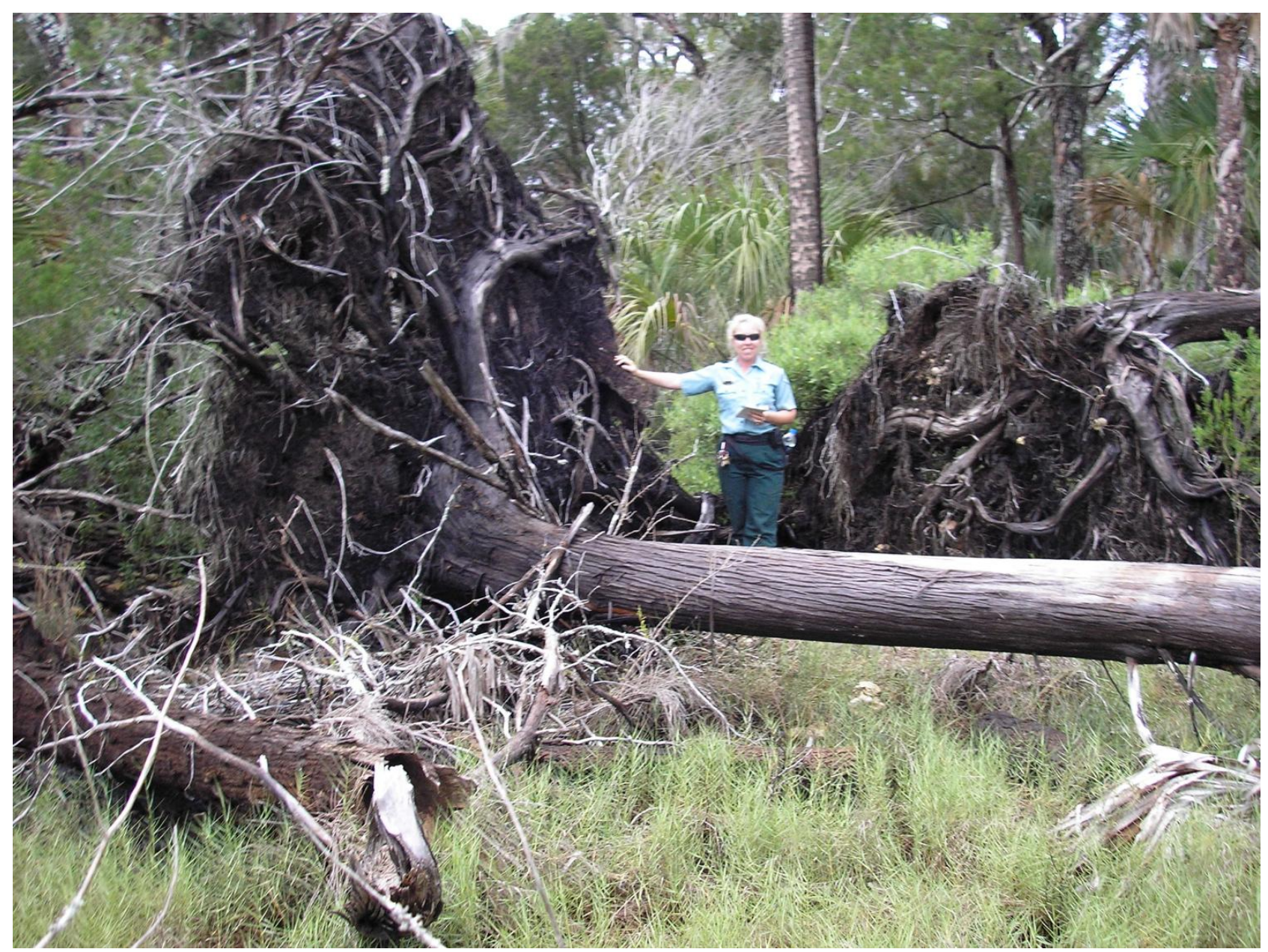

Figure 41. WBPSP Park manager, K. Ebersol, standing between uprooted red cedar with salt grass colonizing sediments.

The mechanics of seawater discharge through FAS vents include dynamic hydrologic interactions among the potentiometric surface of fresh groundwater and sea level, chemical alteration of seawater as it passes through subterranean conduits, secondary dolotomization of the limestone through which it passes, and seasonal variations in the amount of discharge and its proximity to the coast (Fanning and others, 1981; Michael and others, 2005; Hughes and others, 2007). Hughes and others (2007) illustrated the combined affects of free convection (heat) and forced convection (ocean/aquifer interface) and the resulting discharge at focused locations.

The potential exists for flow and mixing of recirculated marine waters through FAS karst conduits in Waccasassa Bay, further complicating the hydrology and geochemistry of the region. The number and distribution of mapped temperature anomalies and the estuarine salinity readings at inland sites underscores the role of inherited geologic structure in groundwater-flow paths and the effects to be expected from interactions between fresh groundwater and recirculating seawater. 


\section{Conclusion}

Temperature anomalies associated with groundwater discharge from the FAS were identified in coastal surface-water bodies across coastal Levy County with TIR imagery acquired in predawn hours. The March 2009 TIR imagery provided a snapshot of discharge vents and their distribution across the WBPSP landscape, including several submarine vents. Water was clearly distinguishable from other surface materials in the TIR imagery, and strong temperature contrasts were detected in surface-water bodies with discharge vents. Through a comparison with 2005 TIR imagery, it was determined that there was a 33-percent risk of omission in the 2009 data set, likely due low rainfall, a low water table, and prolonged drought.

Identified sites appear in dense clusters and as scattered sites across the landscape. Concentrations of multiple "hot spots" were located in artificial features such as borrow pits and the Florida Barge Canal, implying strong aquifer discharge at such sites. Natural sites showed a northwest, southeast trend, reflecting the underlying structure of the Ocala Limestone and its role in the distribution of seeps and groundwater flow in this region. Additionally, the position of the Cedar Keys along the Floridan Plateau central axis indicates geothermally heated seawater may be a source of aquifer flow in the region. Although the imagery was only used to evaluate water temperature, other applications of the imagery for landscape evaluations may be feasible.

\section{Acknowledgments}

The authors acknowledge the support and time of State employees Jeff DiMaggio, Kristin Ebersol, and David Hoyt (Florida State Parks), Mark Dehaven and Mike Kuhman (Florida Department of Agriculture and Consumer Services), volunteers Rod Hunt and Tommy Allen (Florida State Parks), and USGS reviewers Rick Spechler and Ann Tihansky. Acknowledgment also goes to David Stonehouse of VeriMap for his efforts to deliver high-quality products under difficult circumstances.

\section{Products}

Several GIS products were derived from the imagery for use by the Park:

- Raster image with 6.5-ft resolution in degrees Fahrenheit

- Polygon shape file depicting temperature anomalies representing Levels 1-4

- Level 4 temperature-anomaly point locations

- Level 4 point locations separated to natural and artificial features

Imagery at a 6.5 -ft resolution in degrees Fahrenheit may be useful for background display purposes. In addition to temperature, this imagery clearly shows surface-water bodies and surfacedrainage paths during March 2009, and may serve as a guide in the future for evaluation of wetlands, coastal forest, and other habitats.

The actual aerial extent of imagery covered the Gulf Coast north to Jefferson County because available airtime and mobilization costs supported a single, large data-acquisition effort. This extension, beyond the limits of WBPSP, may benefit the larger scientific and resource-management community of the State of Florida, National Wildlife Refuges, State Water Management Districts, counties of the Nature Coast, and academia. The additional imagery was collected and may be available to the State of Florida as a series of tiled images from VeriMap Inc.:

- 3-mi. swath of TIR imagery from Cedar Key north to St. Marks

- Coregistered RGB near infrared (nIR) or natural-color aerial photography for Waccasassa Bay and the northern Nature Coast 


\section{References Cited}

Anderson, M.P., 2005, Heat as a ground water tracer: Ground Water, v. 43, no. 6, p. 951-968.

Astaras, T., and Oikonomidis, D., 2006, Remote sensing techniques to monitoring coastal plain areas suffering from salt water intrusion and detection of fresh water discharge in coastal, karstic areas: case studies from Greece, in Baba, A., Howard, K.W.F., and Gunduz, O., eds., Groundwater and Ecosystems: Springer Netherlands, p. 1-13.

Bayari, C.S., and Kurttas, T., 2002, Coastal and submarine karstic discharges in the Gokova Bay, SW Turkey, v. 35, no. 4, p. 381-390.

Beatty, G.F., 1977, The study of lineaments and fracture traces and correlation to springs along the Suwannee River from Mayo, Florida, to Branford, Florida: Gainesville, University of Florida, Masters Thesis, 89 p.

Beck, J., 2004, Capabilities of airborne infrared remote sensing systems to detect hotspots: Advantage, v. 5, no. 11, p. 1-15.

Breier, J.A., 2006, The Impact of Groundwater Flows on Estuaries, Aquifers of the Gulf Coast of Texas: Austin, TX, The University of Texas at Austin-Marine Science Institute p. 165-172.

Brooks, H.K., 1981, Physiographic divisions of Florida: map and guide; Florida Cooperative Extension Service; University of Florida, Gainesville, Florida, USA: Institute of Food and Agricultural Science, University of Florida.

Budd, D.A., Loizeaux, N.T., and Dumont, K.A., 1997, Facies-controlled hydrogeologic units in the Ocala Limestone of the upper Floridan Aquifer, west-central Florida, in Geological Society of America (GSA) 1997 Annual Meeting, Salt Lake City, UT, 20-23 Oct 1997, GSA, Boulder, CO, p. 112.

Burnett, W.C., Bokuniewicz, H., Huettel, M., Moore, W.S., and Taniguchi, M., 2003, Groundwater and pore water inputs to the coastal zone: Biogeochemistry, v. 66, no. 1, p. 3-33.

Burnett, W.C., Chanton, J., Rutkowski, C., Corbett, D.R., Dillon, K., Cable, J., Schmidt, W., Lloyd, J.M., and Collier, C., 2000, Tracing groundwater flow into the northeastern Gulf of Mexico coastal zone, in The Wakulla Springs Woodville Karst Plain Symposium, Oct. 9, 1998, FGS, Tallahassee, FL, p. 63.

Cable, J.E., Burnett, W.C., and Chanton, J.P., 1997, Magnitude and variations of groundwater seepage along a Florida marine shoreline: Biogeochemistry, v. 38, no. 2, p. 189-205.

Cable, J.E., Burnett, W.C., Chanton, J.P., and Weatherly, G.L., 1996, Estimating groundwater discharge into the northeastern Gulf of Mexico using radon-222: Earth and Planetary Science Letters, v. 144, no. 3-4, p. 591-604.

Chudnovsky, A., Ben-Dor, E., and Saaroni, H., 2004, Diurnal thermal behavior of selected urban objects using remote sensing measurements: Energy \& Buildings, v. 36, no. 11, p. 1063-1074.

Cooke, C.W., 1945, Geology of Florida: The Florida Geological Survey Bulletin No. 29, 339 p.

Coultas, C.L., and Hsieh, Y.-P., 1997, Ecology and management of tidal marshes: a model from the Gulf of Mexico: Delray Beach, FL, St. Lucie Press, 355 p.

Dalsted, K.J., Worcester, B.K., and Brun, L.J., 1979, Detection of saline seeps by remote sensing techniques: Photogrammetric Engineering and Remote Sensing, v. 45, no. 3, p. 285-291.

Danielescu, S., MacQuarrie, K.T.B., and Faux, R.N., 2009, The integration of thermal infrared imaging, discharge measurements and numerical simulation to quantify the relative contributions of freshwater inflows to small estuaries in Atlantic Canada: Hydrological Processes, v. 23, no. 20, p. 2847-2859. 
Davis, J.B., 2007, Aerial thermography surveys to detect groundwater discharge in the St. John's River Water Management District, Northeast Florida, American Society for Photogrammetry and Remote Sensing Annual Conference Proceedings: Tampa, FL, p. 1-9.

Davis, S.N., Cecil, L.D.W., Zreda, M., and Moysey, S., 2001, Chlorine-36, bromide, and the origin of spring water: Chemical Geology, v. 179, no. 1-4, p. 3-16.

Denizman, C., and Randazzo, A.F., 2000, Post-Miocene subtropical karst evolution, lower Suwannee River Basin, Florida: Bulletin of the Geological Society of America, v. 112, no. 12, p. 1804-1813.

DeWitt, D.J., 2003, Submarine springs and other karst features in offshore waters of the Gulf of Mexico and Tampa Bay, Southwest Florida Water Management District: Southwest Florida Water Management District, $112 \mathrm{p}$.

Drury, S.A., 2001, Image Interpretation in Geology (3rd ed.): Malden, MA, Blackwell Science, Inc.

Fanning, K.A., Byrne, R.H., Breland, J.A., Betzer, P.R., Moore, W.S., Elsinger, R.J., and Pyle, T.E., 1981, Geothermal springs of the West Florida continental shelf: Evidence for dolomitization and radionuclide enrichment: Earth and Planetary Science Letters, v. 52, p. 345-354.

Faulkner, G.L., 1973, Ground-Water Conditions in the Lower Withlacoochee River-Cross-Florida Barge Canal Complex Area: U.S. Geological Survey, Tallahassee, FL Water Resources Investigation Report 4-72, 37 p.

Faux, R.N., Lachowsky, H., Maus, P., Torgersen, C.E., and Boyd, M.S., 2001, New approaches for monitoring stream temperature: Airborne thermal infrared remote sensing, Inventory and Monitoring Project Report Integration of Remote Sensing, Remote Sensing Applications Laboratory, U.S. Dept. Agriculture, Forest Service, 32 p.

Federal Register, 2008, Notice of Intent FL200803124108C: Levy County, U.S. Dept. of Defense Corps of Engineers, v. 73, no. 33, p. 9103; V. 9173:9133.

Fleury, P., Bakalowicz, M., and de Marsily, G., 2007, Submarine springs and coastal karst aquifers: A review: Journal of Hydrology, v. 339, no. 1-2, p. 79-92.

Florida Department of Agriculture and Consumer Services (DACS), 2009, Division of Aquaculture, LIVE Water Monitoring; accessed May 5, 2009, at http://www.floridaaquaculture.com/.

Focardi, S., De Marinis, A.M., Rizzotto, M., and Pucci, A., 2001, Comparative evaluation of thermal infrared imaging and spotlighting to survey wildlife: Wildlife Society Bulletin, p. 133-139.

Havens, K.J., and Sharp, E.J., 1998, Using thermal imagery in the aerial survey of animals: Wildlife Society Bulletin, v. 26, no. 1, p. 17-23.

Healy, H.G., 1975, Terraces and shorelines of Florida: Florida Dept. of Natural Resources, Bureau of Geology, Map Series No. 71; size 21"x17".

Heath, R.C. andConover, C.S., 1981, Hydrologic Almanac of Florida: U.S. Geological Survey OpenFile Report 81-1107, 239 p.

Henry, J.A., Portier, K.M., and Coyne, J., 1994, The climate and weather of Florida: Sarasota, Fla, Pineapple Press, 279 p.

Hine, A.C., Belknap, D.F., Hutton, J.G., Osking, E.B., and Evans, M.W., 1988, Recent geological history and modern sedimentary processes along an incipient, low-energy, epicontinental-sea coastline; Northwest Florida: Journal of Sedimentary Petrology, v. 58, no. 4, p. 567-579.

Hughes, J.D., Vacher, H.L., and Sanford, W.E., 2007, Three-dimensional flow in the Florida Platform: Theoretical analysis of Kohout convection at its type locality: Geology, v. 35, no. 7, p. 663.

Katz, B., Copeland, R., Greenhalgh, T., Ceryak, R., and Zwanka, W., 2005, Using multiple chemical indicators to assess sources of nitrate and age of groundwater in a karstic spring basin: Environmental and Engineering Geoscience, v. 11, no. 4, p. 333. 
Kincaid, T.R., 2009, Survey of Groundwater Discharges in the Waccasassa Bay Area Between Dowry Creek and Beetree Slough: H2H Associates, LLC, 26 p.

Kindinger, J.L., Davis, J.B., and Flocks, J.G., 2000, Subsurface Characterization of Selected Water Bodies in the St. Johns River Water Management District, Northeast Florida: U.S. Geological Survey Open-File Report 00-180; Section H; 5 p.

Kohout, F.A., 1967, Ground-Water Flow and the Geothermal Regime of the Floridian Plateau (1):

Transactions--Gulf Coast Association of Geological Societies; v. 17, p. 339-354.

Kohout, F.A., Henry, H.R., and Banks, J.E., 1977, Hydrogeology related to geothermal conditions of the Floridian Plateau, in Smith, D.L., and Griffin, G.M., eds., The Geothermal Nature of the Floridian Plateau. Florida Bureau of Geology Special Publication 21, p. 1-41.

Kohout, F.A., Munson, R.C., Turner, R.M., and Royal, W.R., 1979, Satellite observations of a geothermal submarine spring off Florida west coast, in Fifth Annual William T. Pecora Memorial Symposium on Remote Sensing, Sioux Falls, SD, p. 570-578.

Krest, J.M., Moore, W.S., Gardner, L.R., and Morris, J.T., 2000, Marsh nutrient export supplied by groundwater discharge: Evidence from radium measurements: Global Biogeochemical Cycles, v. 14, no. 1, p. 167-176.

Land, L.A., and Paull, C.K., 2001, Thermal gradients as a tool for estimating groundwater advective rates in a coastal estuary: White Oak River, North Carolina, USA: Journal of Hydrology, v. 248 , no. 1, p. 198-215.

Lane, E., 1994, Florida's geological history and geological resources: Florida Geological Survey Special Publication no. 35, $64 \mathrm{p}$

Lane, E., 2000, The Spring Creek submarine springs group, Wakulla County, Florida: in Wakulla Springs Woodville Karst Plain Symposium, 9 Oct 1998, Florida Geological Survey, Tallahassee, FL., p. 65-77.

Lewelling, B.R., Tihansky, A.B., and Kindinger, J.L., 1998, Assessment of the hydraulic connection between ground water and the Peace River, west-central Florida: U.S. Geological Survey WaterResources Investigations Report 97-4211; Southwest Florida Water Management District; 96 p.

Lillesand, T.M., Kiefer, R.W., and Chipman, J.W., 1994, Remote sensing and image interpretation: New York, John Wiley \& Sons.

Lo, C.P., Quattrochi, D.A., and Luvall, J.C., 1997, Application of high-resolution thermal infrared remote sensing and GIS to assess the urban heat island effect: International Journal of Remote Sensing, v. 18, no. 2, p. 287-304.

Loizeaux, N.T., 1995, Lithologic and hydrogeologic frameworks for a carbonate aquifer evidence for facies controlled hydraulic conductivity in the Ocala Formation, West-Central Florida: University of Colorado, 298 p.

McClean, J.A.R., 2002, GIS Analysis of Landsat 7 Thermal data to identify submarine springs, in Breman, J., ed., Marine Geography: GIS for the Oceans and Seas, p. 49-54.

Michael, H.A., Mulligan, A.E., and Harvey, C.F., 2005, Seasonal oscillations in water exchange between aquifers and the coastal ocean: Nature, v. 436, no. 7054, p. 1145-1148.

Miller, J.A., 1990, Ground Water Atlas of the United States - segment 6, Alabama, Florida, Georgia, and South Carolina: U.S. Geological Survey Hydrologic Atlas HA-730G, 28 p.

Mira, M., Valor, E., Boluda, R., Caselles, V., and Coll, C., 2007, Influence of soil water content on the thermal infrared emissivity of bare soils: Implication for land surface temperature determination: Journal of Geophysical Research (Earth Surface), v. 112, no. F11, p. 04003. 
Moore, W.S., 1999, The subterranean estuary: a reaction zone of ground water and sea water: Marine Chemistry, v. 65, no. 1-2, p. 111-125.

Mulligan, A.E., and Charette, M.A., 2008, Groundwater flow to the coastal ocean, in Geochemistry, Woods Hole Oceanographic Institution.

Mustard, J.F., Carney, M.A., and Sen, A., 1999, The use of satellite data to quantify thermal effluent impacts: Estuarine Coastal and Shelf Science, v. 49, no. 4, p. 509-524.

National Climate Data Center (NCDC), 2009, NOAA Satellite and Information Service; accessed May 5, 2009, at http://www.ncdc.noaa.gov/oa/ncdc.html

National Ocean Service (NOS), 2009, NOAA NOS Tides and Currents, accessed May 5, 2009, at http://tidesandcurrents.noaa.gov/

National Water Information System (NWIS), 2009, U.S. Geological Survey, USGS Water Data for the Nation; accessed May 5, 2009, at http://waterdata.usgs.gov/nwis.

Nuttle, W.K., and Portnoy, J.W., 1992, Effect of rising sea level on runoff and groundwater discharge to coastal ecosystems: Estuarine, Coastal and Shelf Science, v. 34, no. 2, p. 203-212.

Portnoy, J.W., Nowicki, B.L., Roman, C.T., and Urish, D.W., 1998, The discharge of nitratecontaminated groundwater from developed shoreline to marsh-fringed estuary: Water Resources Research, v. 34, no. 11, p. 3095-3104.

Prowell, D.C., 1988, Cretaceous and Cenozoic tectonism on the Atlantic coastal margin, in Sheridan, R.E., and Grow, J.A., eds., The Atlantic Continental Margin, Geology of North America Vol. I-2: Boulder, CO, Geological Society of America, p. 557-564.

Prowell, D.C., 1983, Index of faults of Cretaceous and Cenozoic age in the Eastern United States. U.S. Geological Survey MF-1269: scale 1:2,500,000.

Quattrochi, D.A., and Luvall, J.C., 1999, Thermal infrared remote sensing for analysis of landscape ecological processes: Methods and applications: Landscape Ecology, v. 14, no. 6, p. 577-598.

Raabe, E.A., Streck, A.E., and Stumpf, R.P., 2004, Historic Topographic Sheets to Satellite Imagery: A Methodology for Evaluating Coastal Change in Florida's Big Bend Tidal Marsh: U.S. Geological Survey Open-File Report 02-211, 44 p.

Raabe, E.A., and Bialkowska-Jelinska, E., 2007, Temperature Anomalies in the Lower Suwannee River and Tidal Creeks, Florida, 2005: U.S. Geological Survey Open-File Report 2007-1311, 28 p.

Raabe, E.A., Edwards, R.E., McIvor, C.C., Grubbs, J.W., and Dennis, G.D., 2007, Habitat and Hydrology: Assessing Biological Resources of the Suwannee River Estuarine System: U.S. Geological Survey Open-File Report 2007-1382, 72 p.

Raabe, E.A., Harris, M.S., Shrestha, R.L., and Carter, W.E., 2008, Derivation of Ground Surface and Vegetation in a Coastal Florida Wetland with Airborne Laser Technology: U.S. Geological Survey Open-File Report 2008-1125, 41 p.

Rogers, D.K., 1992, Florida's vanishing palms: Saint Petersburg Times: no. 10A.

Romanov, D., and Dreybrodt, W., 2006, Evolution of porosity in the saltwater-freshwater mixing zone of coastal carbonate aquifers: An alternative modelling approach: Journal of Hydrology, v. 329, no. 34, p. 661-673.

Rudloe, A., 1998, Fresh water impacts in coastal ecosystems: Transactions in The Wakulla Springs Woodville Karst Plain Symposium, Oct. 9, 1998, Florida Geological Survey, Tallahassee, FL, p. 116119.

Sabins, F.F., Jr., 1987, Remote Sensing: Principles and Interpretation: $2^{\text {nd }}$ Ed., New York, W.H. Freeman and Company. 
Scott, T.M., 1992, A Geological Overview of Florida: Florida Geological Survey Open-File Report No. $50,78 \mathrm{p}$.

Scott, T.M., Means, G.H., Meegan, R.P., Means, R.C., Upchurch, S.B., Copeland, R.E., Jones, J., Roberts, T., and Willet, A., 2004, Springs of Florida: Florida Geological Survey No. 66, 66 p.

Shaban, A., Khawlie, M., Abdallah, C., and Faour, G., 2005, Geologic controls of submarine groundwater discharge: application of remote sensing to north Lebanon: Environmental Geology, v. 47, p. 512-522.

Short, N., 2009, Dr. Nicholas Short's Remote Sensing Tutorial, NASA, The Warm Earth: Thermal Remote Sensing; http://rst.gsfc.nasa.gov/Sect9/Sect9_1.html.

Sinclair, W.C., and Stewart, J.W., 1985, Sinkhole type, development, and distribution in Florida: U.S. Geological Survey Map Series No. 110, scale 1:1,267,200.

Singurindy, O., Berkowitz, B., and Lowell, R.P., 2004, Carbonate dissolution and precipitation in coastal environments: Laboratory analysis and theoretical consideration: Water Resources Research, v. 40, no. 4, p. W04401.

Southwest Florida Water Management District (SWFWMD), 2009, Hydrologic Conditions for the month of March 2009: Southwest Florida Water Management District, 81 p.

Southeast Regional Climate Center (SERCC), 2009, University of North Carolina, Chapel Hill, NC, accessed May 5, 2009, at http://www.sercc.com/.

Spechler, R.M., 1994, Saltwater intrusion and the quality of water in the Floridan Aquifer system, northeastern Florida 92-4174, 76 p.

Spechler, R.M., 1996, Detection and quality of previously undetermined Floridan aquifer system discharge to the St. Johns River, Jacksonville, to Green Cove Springs, northeastern Florida: U.S. Geological Survey Water-Resources Investigations Report 95-4257, 29 p.

Spechler, R.M., 2001, The relation between structure and saltwater intrusion in the Floridan aquifer system, Northeastern Florida, in Karst Interest Group Proceedings, Water-Resources Investigations Report 01-4011, St. Petersburg, FL, U.S. Geological Survey, p. 25-29.

Stockton, G.R., 2004, Finding pollution with aerial infrared thermography: Industrial Physicist, v. 10, no. 2, p. 24-27.

Stumpf, R.P., and Haines, J.W., 1998, Variations in tidal level in the Gulf of Mexico and implications for tidal wetlands: Estuarine and Coastal Shelf Science, v. 46, no. 2, p. 165-173.

Suwannee River Water Management District (SRWMD), 2009a, February 2009 Hydrologic Conditions Report for the District: Suwannee River Water Management District, 10 p.

Suwannee River Water Management District (SRWMD), 2009b, March 2009 Hydrologic Conditions Report for the District: Suwannee River Water Management District, 7 p.

Taniguchi, M., Burnett, W.C., Cable, J.E., and Turner, J.V., 2002, Investigation of submarine groundwater discharge: Hydrological Processes, v. 16, no. 11, p. 2115-2129.

Tanner, W.F., Jr., 1960, Florida coastal classification: Transactions--Gulf Coast Association of Geological Societies, v. 10, p. 259-266.

Tcherepanov, E.N., Zlotnik, V.A., and Henebry, G.M., 2005, Using Landsat thermal imagery and GIS for identification of groundwater discharge into shallow groundwater-dominated lakes: International Journal of Remote Sensing, v. 26, no. 17, p. 3649-3661.

Thompson, J., and Marvin, M., 2006, Experimental research using thermography to locate heat signatures from caves, in InfraMation 2006 Proceedings, p. 8.

Tihansky, A.B., 2004, Effects of Aquifer Heterogeneity on Ground-Water Flow and Chloride Concentrations in the Upper Floridan Aquifer near and within an Active Pumping Well Field, West- 
Central Florida: U.S. Geological Survey Tampa Florida Water-Resources Division Scientific Investigations Report 2004-5268, 75 p.

Torgersen, C.E., Price, D.M., Li, H.W., and McIntosh, B.A., 1995, Thermal refugia and chinook salmon habitat in Oregon: Applications of airborne thermal videography, in Proceedings of the 15th Biennial Workshop on Color Photography and Videography, Terre Haute, American Society for Photogrammetry and Remote Sensing, p. 167-171.

Turner, I.L., Coates, B.P., and Acworth, R.I., 1997, Tides, waves and the super-elevation of groundwater at the coast: Journal of Coastal Research, v. 13, no. 1, p. 46-60.

United States National Arboretum (USNA), 2009, USDA Plant Hardiness Zones: Plant Hardiness Zone Map; accessed May 5, 2009, at http://www.usna.usda.gov/Hardzone/ushzmap.html.

VeriMap, 2002, Historical Research Projects, Test to observe aquifer discharge near Cedar Key, FL, Nov. 2002; accessed May 5, 2009, at http://www.verimap.com/html/po-portfolio.htm\#poHistorical

VeriMap, 2009a, VeriMap Plus Inc., Website, Geospatial Image Mapping, EnviroMap: accessed May 5, 2009, at http://www.verimap.com/.

VeriMap, 2009b, Waccasassa Bay Preserve State Park Thermal Infrared Mapping Project for Florida Dept. of Environmental Protection: VeriMap/VeriMarc, 20 p.

Vernon, R.O., 1951, Geology of Citrus and Levy Counties, Florida: Florida Geological Survey Geological Bulletin, no. 33, 256 p.

Watershed Sciences, L., 2002, Aerial Surveys in the Mattole River Basin: Thermal Infrared and Color Videography: North Coast Regional Water Quality Control Board, 22 p.

Watershed Sciences, L., 2004, Aerial Surveys using Thermal Infrared and Color Videography: Scott River and Shasta River Sub-Basins: California North Coast Regional Water Quality Control Board and University of California at Davis, Final Report, 59 p.

White, W.A., 1970, The Geomorphology of the Florida Peninsula: Florida Bureau of Geology Geological Bulletin, no. 51, 163 p.

Williams, K., Ewel, K.C., Stumpf, R.P., Putz, F.E., and Workman, T.W., 1999, Sea-level rise and coastal forest retreat on the west coast of Florida, USA: Ecology, v. 80, no. 6, p. 2045-2063.

Wolfe, S.H., 1990, An ecological characterization of the Florida springs coast: Pithlachascotee to Waccasassa Rivers, 323 p. 
